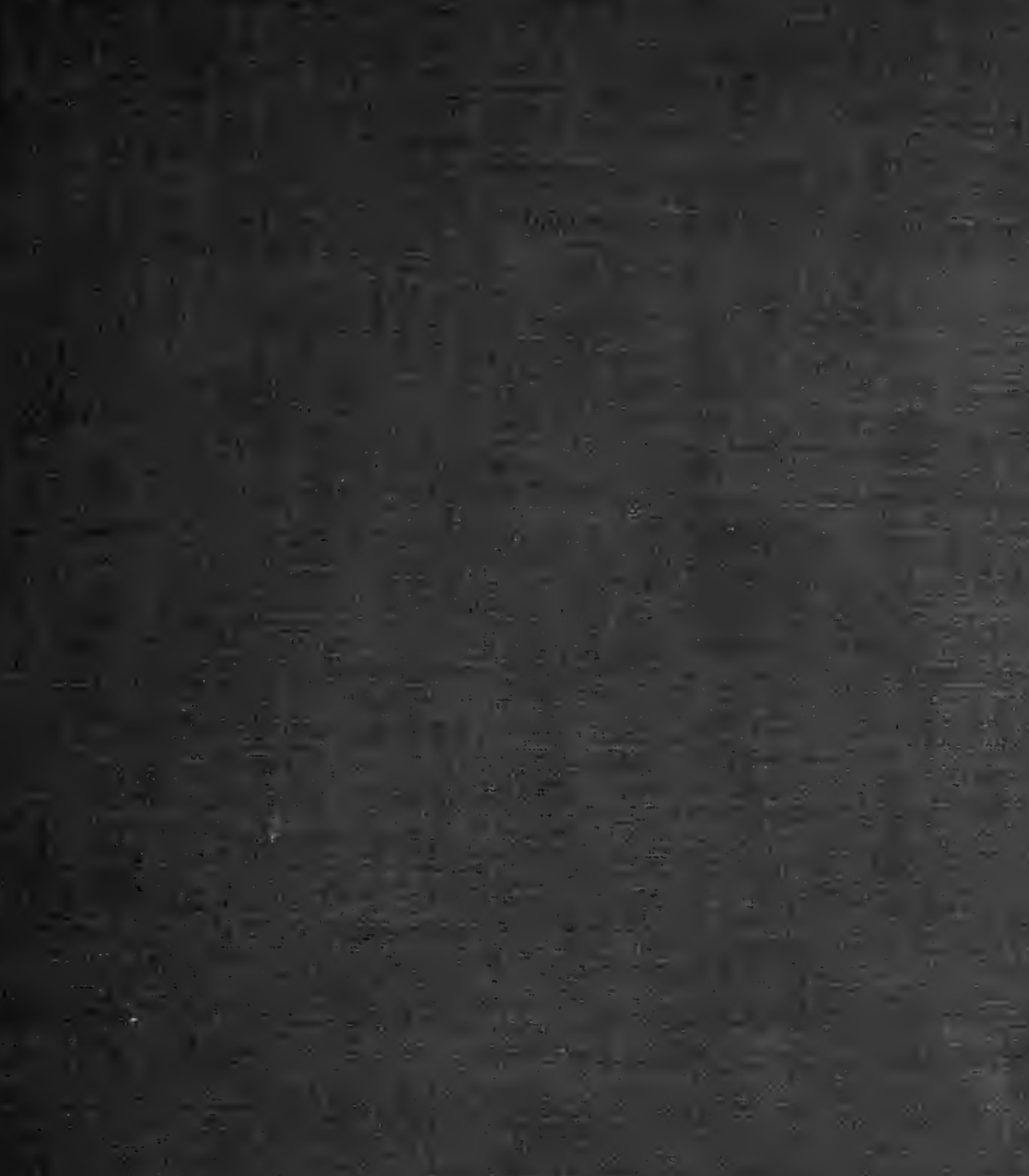

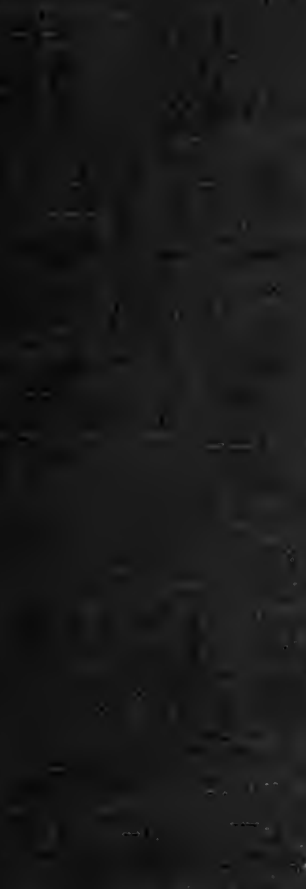

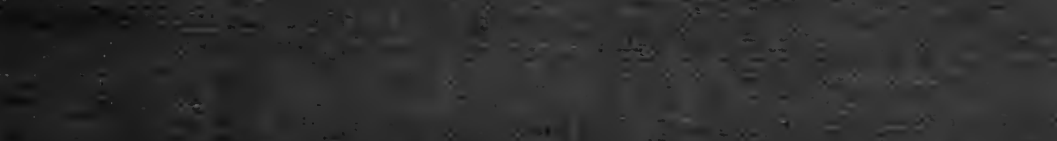

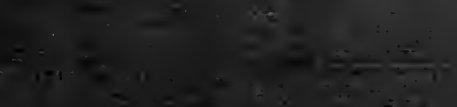

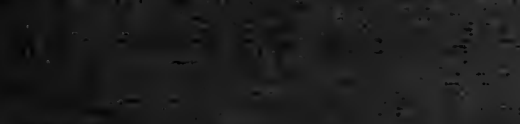

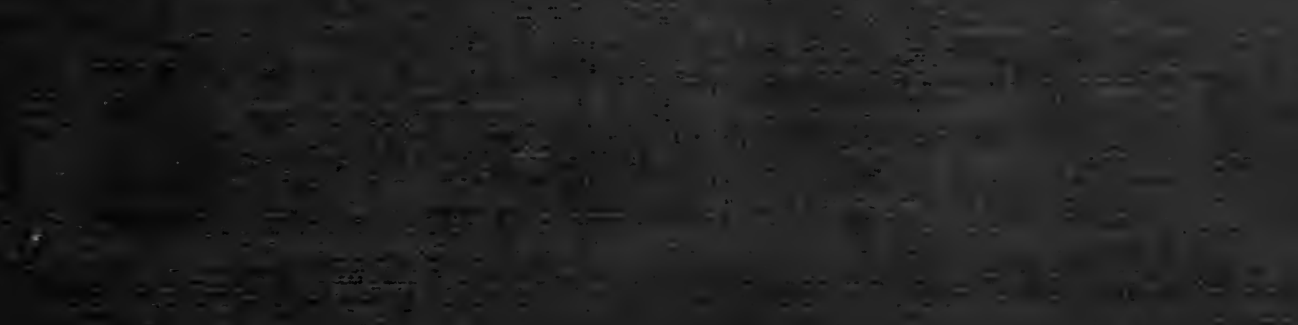

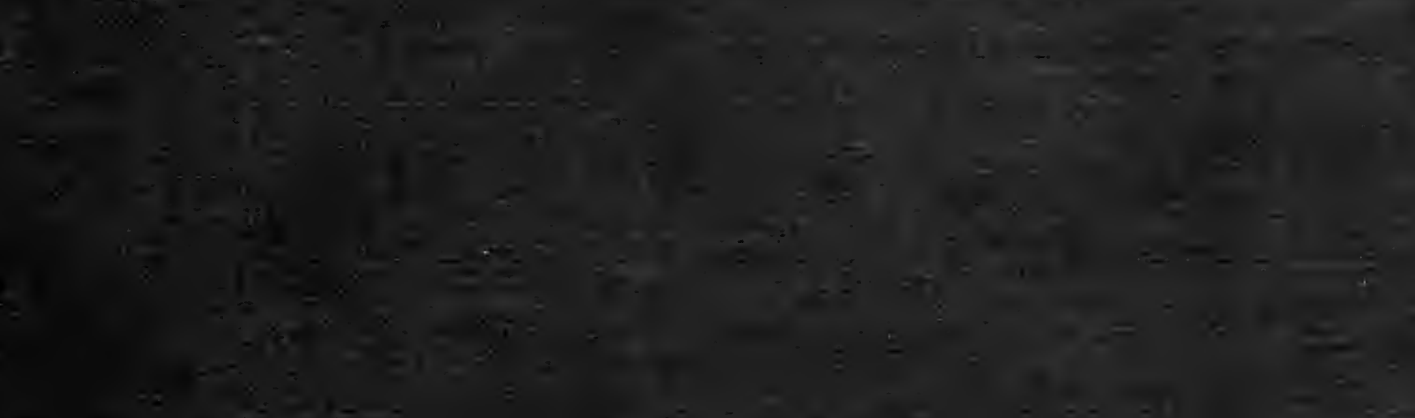


Digitized by the Internet Archive in 2007 with funding from Microsoft Corporation 
UNIVERSITY OF CALIFORNIA PUBLICATIONS

IN

AMERICAN ARCHAEOLOGY AND ETHNOLOGY

Vol. 5, No. 5, pp. 293-380

August 19,1910

\section{THE CHIMARIKO INDIANS AND \\ LANGUAGE}

BY

ROLAND B. DIXON 


\section{UNIVERSITY OF CALIFORNIA PUBLICATIONS}

DEPARTMENT OF ANTHROPOLOGY

The following publications dealing with archaeological and ethnological subjects issued under the direction of the Department of Anthropology are sent in exchange for the publications of anthropological departments and museums, and for journals devoted to general anthropology or to archaeology and ethnology. They are for sale at the prices stated, which include postage or express charges. Fxchanges should be directed to The Exchange Department, University Iibrary, Berkeley, California, U. S. A. All orders and remittances should be addressed to the University Press.

Vol. 1. 1. Iife and Culture of the Hupa, by Pliny Farle Goddard. Pp. 1-88; plates 1-30. September, 1903

Price

$\$ 1.25$

2. Hupa Texts, by Pliny Earle Goddard. Pp. 89-368. March, 1904 ......... $\$ .00$ Index, pp. 369-378.

Vol. 2. 1. The Exploration of the Potter Creek Cave, by William J. Sinclair. Pp. 1-27; plates 1-14. April, 1904

2. The Ianguages of the Coast of California South of San Francisco, by

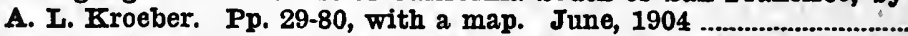

3. Types of Indian Culture in California, by A. I. Kroeber. Pp. 81-103. June, 1904

4. Basket Designs of the Indians of Northwestern California, bJ A. $\mathbf{I}$. Kroeber. Pp. 105-164; plates 15-21. January, 1905

5. The Yokuts Language of South Central California, by A. I. Kroeber. Pp. 165-377. January, 1907 Index, pp. 379-393.

Vol. 3. The Morphology of the Hupa Language, by Pling Farle Goddard.

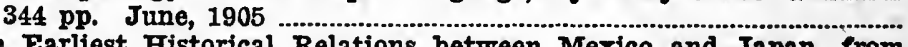

Vol. 4. 1. The Earliest Historical Relations between Mexico and Japan, from original documents preserved in Spain and Japan, by Zelia Nuttall. Pp. 1-47. April, 1906

2. Contribution to the Physical Anthropology of Califormia, based on collections in the Department of Anthropology of the University of California, and in the U. S. National Museum, by Ales Frdlicka. Pp. 49-64, with 5 tables; plates 1-10, and map. June, 1906 February, 1907

4. Indian Myths from South Central California, bJ A. I. Kroeber. Pp. 167-250. May, 1907

5. The Washo Ianguage of East Central California and Nevada, by A. I. Kroeber. Pp. 251-318. September, 1907

6. The Religion of the Indians of California, by $A$. I. Kroober. Pp. 319356. September, 1907

$$
\text { Index, pp. 357-374. }
$$

Vol. 5. 1. The Phonology of the Hupa Ianguage; Part I, The Individual Sounds, by Pliny Earle Goddard. Pp. 1-20, plates 1-8. March, 1907 .............

2. Navaho Myths, Prayers and Songs, with Texts and Translations, by Washington Matthews, edited by Pliny Earle Goddard. Pp. 21-63. September, 1907

3. Kato Texts, by Pliny Earle Goddard. Pp. 65-238, plate 9. December, 1909

4. The Material Culture of the Klamath Lake and Modoc Indians of Northeastern Califormia and Southern Oregon, by 8. A. Barrett. Pp. 239-292, plates 10-25. June, 1910

5. The Chimariko Indians ard Language, by Roland B. Dixon. Pp. 293380. August, 1910

Vol. 6. 1. The Ethno-Geography of the Pomo and Neighboring Indians, by Samuel Alfred Barrett. Pp. 1-332, maps 1-2. February, 1908

2. The Geography and Dialects of the Miwok Indians, by Samuel Alfred Barrett. Pp. 333-368, map 3.

3. On the Evidence of the Occupation of Certain Regions by the Miwok Indians, by A. I. Kroeber. Pp. 369-380. Nos. 2 and 3 in one cover. February, 1908 Index, pp. 381-400.

Vol. 7. 1. The Emeryvillo Shellmound, by Max Uhle. Pp. 1-106, plates 1-12, with 38 text figures. June, 1907

2. Recent Investigations bearing upon the Question of the Occurrence of Neocene Man in the Auriferous Gravels of California, by William J. Sinclair. Pp. 107-130, plates 13-14. February, 1908

3. Pomo Indian Basketry, by S. A. Barrett. Pp. 133-306, plates 15-30, 231 'text figures. December, 1908

4. Shellmounds of the San Francisco Bay Region, by. N. C. Nelson

Pp. 309-356, plates 32-34. December, 1909 ...........................
5. The Ellis Landing Shellmound, by N. C. Nelson. Pp. 357-426, plates 36-50. April, 1910 Index, pp. 427-441. 


\section{THE CHIMARIKO INDIANS AND \\ LANGUAGE.}

$\mathrm{BY}$

ROLAND B. DIXON.

\section{CONTENTS.}

Part I. Culture.

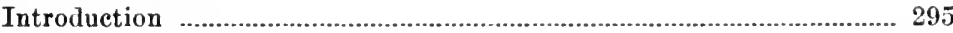

Territory and History .................................................................... 295

Material Culture ............................................................................... 298

Social Organization ........................................................................ 301

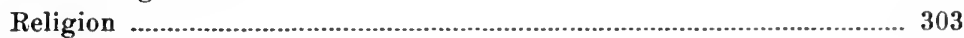

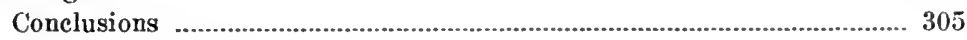

Part II. Language.

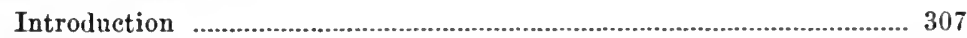

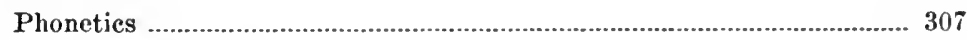

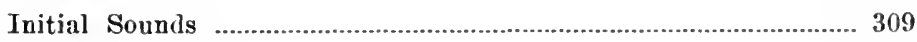

Terminal Sounds .......................................................................... 309

Dialectical Differences ................................................................. 309

Combinations of Sounds .............................................................. 310

Influence of Sounds on One Another ............................................ 310

Summary ........................................................................................... 311

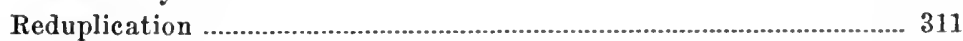

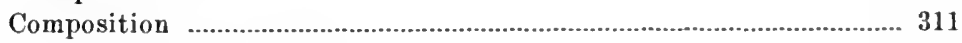

A. Prefixes or Suffixes ............................................................... 318

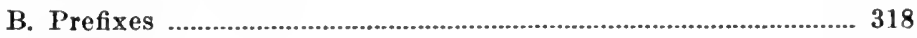

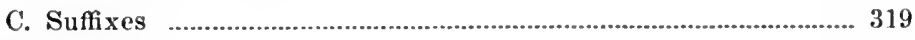

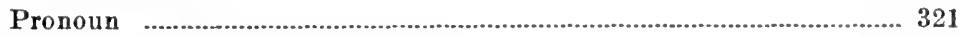

Independent Personal Pronoun ......................................................... 322

Demonstratives .............................................................................. 322

Interrogatives ......................................................................... 322

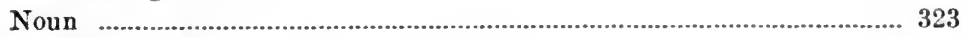

Case Suffixes .............................................................................. 323

Number .................................................................................... 323

Possessive _................................................................................. 323 


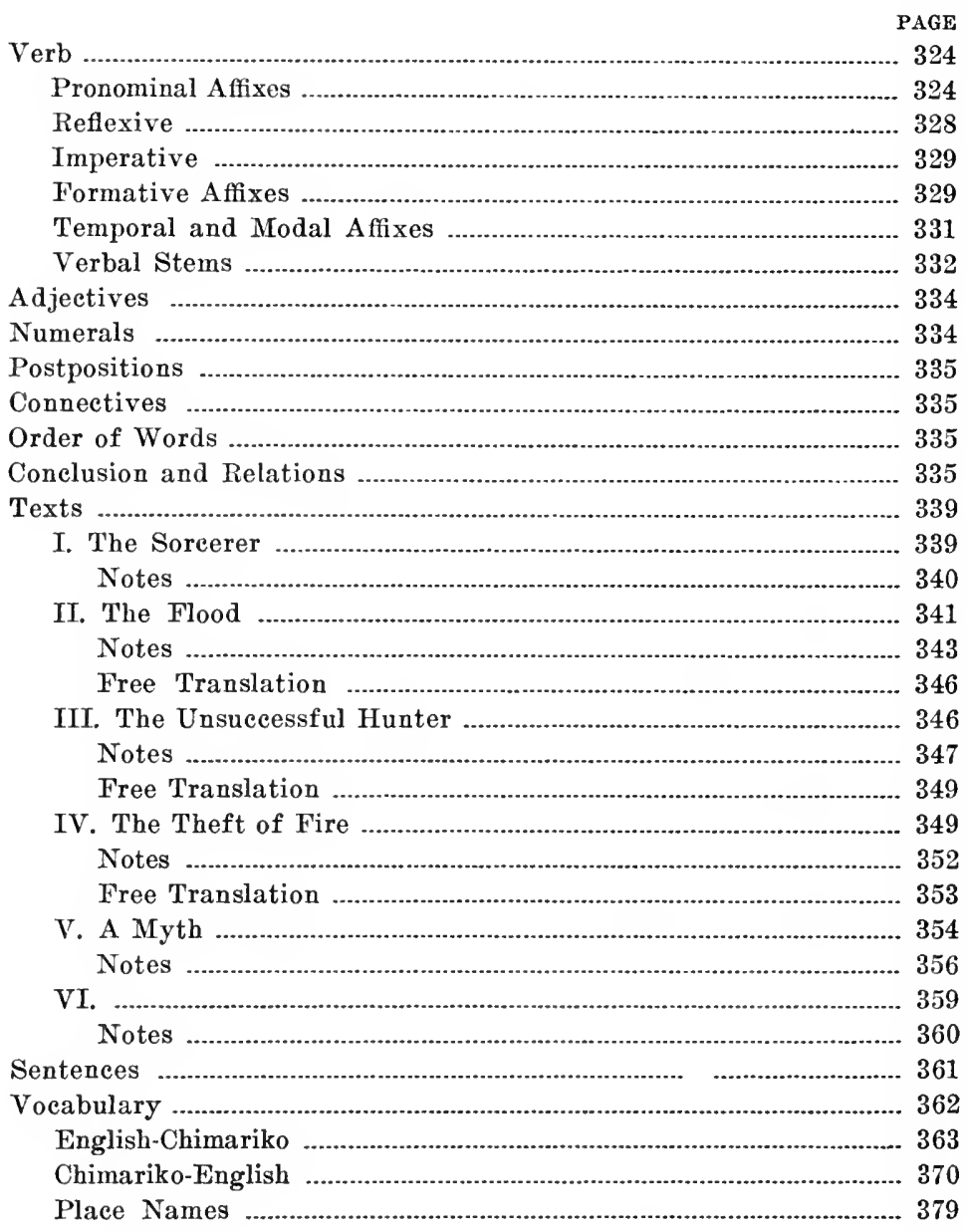




\section{PART I. CULTURE.}

\section{INTRODUCTION.}

The investigation in the course of which the material was secured upon which the following account of the culture and language of the Chimariko Indians of California is based, was conducted during July and August, 1906, on behalf of the Department of Anthropology of the University of California, and, in common with the other researches of the Department, was made possible by the support of Mrs. Phoebe A. Hearst. At the present time there appear to be only two living full-blood Chimariko. One of these, Doctor Tom, a half-crazy old man, proved worthless for purposes of investigation, and the bulk of the information secured was obtained from Mrs. Dyer, a failing old woman of about eighty years of age, living on lower New River. Some supplementary details were gathered from "Friday," a well-known character near the Hupa reservation, half Hupa and half Wintun by birth, but having had close affiliations with the Chimariko many years ago.

The little group of Indians to whom the name Chimariko has been given oceupied a small area situated in the western portion of Trinity County, in northern California. The language spoken by the group has always been believed to differ radically from all others known, so that, unless certain resemblanees discussed in the linguistic portion of this paper are accepted as establishing an affinity with the Shastan family, the Chimariko by themselves constitute an independent linguistic stock. In the small size of the area oceupied, the Chimariko fall into the same class with several other stocks in California, such as the Yana and the extinet Esselen.

\section{TERRITORY AND HISTORY.}

As far as can be ascertained at present, the Chimariko seem to have regarded as their territory a narrow strip of country extending along Trinity River from the mouth of the South Fork 
up as far as Taylor's Flat at French Creek. This upper limit is well corroborated by repeated statements of the Wintun, who controlled all the upper Trinity, reaching as far downstream as Cox's or Big Bar, some five or six miles above French Creek. In addition to this strip of territory along the main Trinity, there is some evidence to the effect that the Chimariko also extended up the South Fork to a point about fifteen miles above Hyampom, and also up Hay Fork as far as the mouth of Corral Creek. These statements in regard to this extension up the South Fork are rather confusing and somewhat contradictory, but appear to be confirmed by the testimony of the Wintun in Hay Fork Valley. In view, however, of positive statements secured by Dr. P. E. Goddard from the Athabascan tribes on the upper South Fork, to the effect that they occupied the South Fork as far as its mouth, the extension up this stream of the Chimariko may be considered doubtful.

Whether or not the so-called Chimalakwe of New River formed a portion of the Chimariko, or were identical with them, is a matter which must apparently remain unsettled. Powers declares $^{1}$ that the Chimalakwe occupied New River, and that they were in process of conquest and absorption by the Hupa at the time of the first appearance of the whites. The upper portion of New River, about New River City and perhaps below, was occupied according to Shasta accounts by a small branch of the Shastan family, speaking a distinct dialect." Satisfactory statements in regard to the occupants of lower New River cannot now be secured. The survivors of the Chimariko most emphatically deny that they ever permanently occupied any part of New River, stating that they merely visited and ascended it a short distance, and only for the purpose of hunting. The people living on New River are declared to have been very few, and to have spoken a Hupa dialect. It is unquestionable that the name Chimalakwe, given to the New River tribe by Powers, is derived from the same stem tcimal, tctmar ${ }^{3}$ as Chimariko. Inasmuch as

1 Powers, S., Tribes of California, Washington, 1877. Contributions to North American Ethnology, III, p. 92.

2 Dixon, R. B., The Shasta-Achomawi: A New Linguistic Stock, with Four New Dialects. American Anthropologist, n. s., VII., pp. 241-315.

${ }^{3} \mathrm{Te}=$ English $\mathrm{ch}, \mathrm{c}=\mathrm{sh}$. See the diseussion of phoneties in the linguistic part. 
these New River people are entirely extinct, and the Chimariko virtually so, it seems doubtful if the question of their relationship can now be definitely settled.

According to the information procured, the Chimariko had only a few small villages within the small area they occupied; that at Burnt Ranch, 'Tsuda'ndadji, being the largest. Other villages of which names and locations were secured were at Cedar Flat, Hầ'dinakteohâda; Hawkin's Bar, Hamai'dadji; Taylor's Flat, Tciteā'nma; Big Bar, Citimaadjè; and one known as Mansūidji on the Trinity River just above the mouth of the South Fork. In addition to these the following names of places on New River were obtained, but were said to have been mere temporary hunting camps: Itcxapo'sta, Dyer's; Paktō'nadji, Patterson's ; and Mai'djasore, Thomas'.

The earliest contact of the Chimariko with the whites probably took place in the second or third decade of the nineteenth century, when the first trappers of the fur companies made their appearance in this region. This first contact was, however, of small moment compared with the sudden irruption into the region of the gold-seekers who, in the early fifties, overran the whole middle and upper Trinity River. From this time on for fifteen years or more, the placers of the seetion were largely worked, and the inevitable conflicts between the miners and the Indians occurred. In the sixties the feeling was particularly bitter, and the unequal contest resulted in the praetical annihilation of the Chimariko. A few remnants fled, taking refuge either with the IIupa, or on the upper Salmon River, or in Scott Valley with tribes belonging to the Shastan stock. From here, after an exile of many years, the survivors, then numbering only some half-dozen, straggled back to their old homes; and of this handful all are now gone except one old man and woman, besides whom there are two or three mixed bloods who have little or no knowledge of the earlier culture of the stock.

What may have been the population of the area before the coming of the whites it is impossible to say. In all probability it could not have numbered more than some hundreds. 


\section{MATERIAL CULTURE.}

The dress of the Chimariko seems to have been to some extent a compromise between that of the Wintun and the Hupa. Men apparently wore no breech-clout, merely wrapping a deer-skin about the waist, and adding to this in winter a deer-skin mantle. Moccasins were worn only in the winter months. Women wore a buckskin fringe or apron in front, reaching from the waist to the knee, and about ten inches in width. A second apron or halfskirt was also worn behind, similar in general to those worn by the Hupa, but plain and unfringed. A basket cap was worn on the head. In winter time men wore snow-shoes, which were made by bending a hazel stick in a circle or hoop, and tying to this two cross-sticks at right angles to each other. The foot was securely tied on by a buckskin lashing.

Bodily decoration and ornament were more restricted than among the Hupa. Dentalia and abalone were used to some extent, as was also a variety of small cylindrical beads, said to have been made of bone. All of these were, however, sparingly employed. Dentalia, if large, were sometimes wrapped spirally with narrow strips of snake-skin, and were measured by the string, the unit of length being from the thumb to the tip of the shoulder.

The ears were generally pierced, but not the nose, and tattooing was less elaborate than among the Trinity Wintun. These latter tattooed the whole cheek up to the temples, and also the chin, whereas the Chimariko, like the Hupa, confined themselves to a few lines on the chin only. The tattooing was restricted to the women alone, and was effected by the same method as among the Shasta, namely by fine, parallel cuts rather than by puncture. The process was begun early in life, and the lines broadened by additions from time to time, until in some cases the chin became an almost solid area of blue. Certain women were particularly skillful in the work, and were much in demand.

The food supply of the Chimariko was formerly abundant. The Trinity River supplied them with ample quantities of salmon, which were split and dried in the usual manner, and preserved either in this or in powdered form. Eels were another important source of food. Deer, elk, and bear constituted the 
larger part of the game supply, in addition to which mountainlion and several other animals supplied an occasional meal. Yellow-jacket larvae were considered delicacies, but grasshoppers and worms, relished by the Sacramento Valley tribes, were not eaten.

As among most California Indians, vegetable products, and particularly acorns, formed a large element in the food supply. The acorns were prepared and eaten in the same manner as among the Hupa and Maidu. ${ }^{4}$ Grass-seeds of various kinds, pine-nuts, berries, and roots of several varieties were gathered in large quantities, and eaten either fresh or dried.

In cooking, deer-meat was either roasted or boiled, whereas for bear-meat only the latter method was practiced.

None of the old type of houses built by the Chimariko now survive. As described they were roughly similar to those of the Hupa, but ruder. The structure was made of fir-bark slabs, and in shape was round or oval. The usual diameter of the house was from ten to fourteen feet, and the interior was as a rule excavated to a depth of about one foot. The ridge-pole was supported by two posts, and the simple gable roof, in general like that of the Hupa, was not provided with any earth covering. The low side-walls were formed of vertical slabs of bark. At one end of the house was the door, small, but not rounded, and closed by a movable piece of bark. At the end opposite the door was a small draught-hole, through which game was always hauled in. Along the sides of the house were the sleeping places, consisting of beds of grass, leaves, and pine-needles, covered with skins.

In addition to this dwelling house, awa', the Chimariko had a sweat-house, ma'tta. This was circular, excavated to a depth of two or three feet, and had the fireplace somewhat back of the center. The roof was of brush and earth, without any smokehole. Houses of this type would aceommodate eight or ten men, and in these houses were held the so-called sweat-dances. This type of house seems on the whole to be rather more like the earth lodges of the Sacramento Valley than the taikyuw of the Hupa. It is stated that there were no menstrual lodges of any sort.

4 Goddard, P. E., Life and Culturo of the Hupa, Univ. Calif. Publ. Am. Arch. Ethn., I, pp. 21-29; Dixon, R. B., The Northern Maidu, Bull. Am. Mus. Nat. Hist., XVII., pp. 184-187. 
The furnishings of the houses were simple. Baskets exclusively were used for storage and cooking, and the soap-stone troughs and vessels of the Hupa appear to have been lacking. For stirring acorn-mush a simple paddle was in use. Information as to spoons was contradictory, one informant declaring that carved spoons like those of the Hupa ${ }^{5}$ were employed, the other that this was not the case. The cylindrical wooden trunks of the Hupa were not known.

Knives and arrowpoints were as a rule made of obsidian, obtained either from the Wintun or the Redwood Creek Indians. Both informants declared that no axes or adzes were made, and that trees, if eut, were laboriously hacked with small knives.

The bow was of yew as a rule, flat, sinew-backed, and resembling the usual type of bow in Northwestern California. ${ }^{6}$ Arrows were generally made of syringa, and were carried in a quiver of raccoon, wild-cat or fawn skin. In shooting the bow was held horizontally. For armor, the Chimariko used an elk-hide robe coming down to the knees, the heavy skin of the neck standing up in front of the face. Slat or stick armor is said not to have been used.

Canoes were not made by the Chimariko, and rivers and streams were crossed by swimming, or on rude rafts, built of logs.

Pipes were made, according to one account, similar to those of the Hupa, with neatly formed stone bowls. ${ }^{7}$ Other accounts, however, state that the pipe was much cruder, and made like that of the Wintun, without stone and with a large bowl.

For musical instruments the Chimariko made chief use of the flute. This had four holes, and was used chiefly in courting. Rattles are declared to have been only sparingly used.

Fish-spears were, like the arrows, made of syringa, and had bone points. Nets, apparently identical with those of the Hupa, were largely used in eatching salmon. Basketry, of which no specimens now survive, was considerably developed. The baskets were exclusively of the twined variety, and in pattern were declared to have been similar to those of the northern Wintun. ${ }^{8}$

5 Goddard, op. cit., pl. 16.

- Ibid., pl. 11.

7 Ibid., pl. 17.

8 See Kroeber, A. L., Basket Designs of the Indians of Northwestern California, Univ. Calif. Publ. Amer. Arch. Ethn., II, pl. 21 and passim. Dixon, R. B., Basketry Designs of the Indians of Northern California, Bull. Amer. Mus. Nat. Hist., XVII, pp. 17-19, pl. XXIII, XXIV. 


\section{SOCIAL ORGANIZATION.}

The information seeured in regard to the social organization of the Chimariko is unfortunately rather seanty. In eommon with most California tribes, there was no trace, apparently, of any elan organization, and the only social units were the various village eommunities. Each such village group had its chief or head-man, whose position was usually hereditary in the male line. If the natural suecessor was, however, thought unfit, some one else was elected. The chief led his people in time of war, and seems to have exereised eonsiderable eontrol over the members of the village group.

Any type of social stratifieation into elasses, seen in a rudimentary form among the Hupa, and increasingly northwards into Oregon and Washington, appears here to be lacking; and slavery, whieh was a regular institution among the Hupa, was not known.

The whole area oecupied by the Chimariko was a common hunting ground, and fishing places in the river are also said to have been publie property, without any evidenee of private eontrol as among the Shasta and other neighboring peoples.

The Chimariko were, in general, monogamie. Wives were usually bought from parents, although sometimes a girl would be sent by her parents, as a wife, to a man who was famed as a good hunter and a reliable man. If the girl disliked him, she would bite his hands, and serateh him, until he sent her back to her home. The levirate was a common eustom, and if a man's wife died soon after her marriage her family were bound to give him her sister, or some near relative, as a seeond wife. For this substitute wife, no additional payment was required.

Puberty ceremonials for women were as a whole simple. The girl had to remain secluded in the house for a period of about a month. Much of this time she was obliged to lie down, and be covered up with skins. She was subjeet to many food restrictions, and ate sparingly, always alone, at dawn and sunset. Throughout the period of her seelusion she was obliged to use a seratehing-stick. At times, she was supposed to dance, usually outside the house. In these danees her hair, eut in a bang on 
the forehead, was made with pitch into a series of tassels or tassel-like ringlets, and these were long enough to fall down over her eyes. When the period of seclusion was over, there was generally a feast given by her parents, and another dance, and then the whole was regarded as completed. The ceremony was apparently not repeated at any of the subsequent menstrual periods.

At childbirth a woman was subject to food restrictions, and had to remain in seclusion for two or three weeks.

But little information was obtained in regard to funeral customs. Cremation was declared never to have been practiced, the body always having been buried. The ceremony if possible took place on the day of the death, and a considerable quantity of property, both personal and gifts from relatives, was placed with the body in the grave. Widows cut their hair short, and "cried" for a month, but did not put pitch on their faces and heads. The house of the deceased was sometimes, but not always, destroyed. The persons who dug the grave were considered unclean, and had to undergo a five days' fast, and then bathe before they might again take up their regular life.

The chief gambling game of the Chimariko was the widespread "grass-game" of Central California." It was played here by two players on a side, each player having a single, unmarked bone or stick about two inches long. One side guesses while the other "rolls," shuffing the bones from hand to hand, wrapping them in small bunches of grass, and then presenting their hands, containing these bunches of grass, to the other side that they may guess the relative position of the two bones. Each side is said to have started with ten counters, and one side or the other must win all twenty to come out victor. Details in regard to methods of counting could not be secured.

The cup and ball game, played with salmon vertebrae, was in use; also cats-cradle; and a game in which objects were thrown at a pin or a post, as in quoits.

${ }^{9}$ Dixon, R. B., The Northern Maidu, Bull. Am. Mus. Nat. Hist., XVII, pp. 209-216. 


\section{RELIGION.}

The religious eeremonials of the Chimariko appear to have been more like those of the Shasta than of any other of their neiglibors, in that they had no other dances exeept those of the shaman.

There were, it seems, both men and women shamans, and they might or might not inherit their position. The sign that a person was destined to become a shaman was a series of dreams. These were, in the ease of a man, often the result of solitary visits to remote mountain lakes, in which the person would bathe at dusk. In these dreams, instruetions were given the neophyte by various supernatural beings, and these direetions must be followed exaetly. Later a full-fledged shaman eame and put a "pain" into the mouth of the new member. This ceremony was accompanied by dances, held out of doors, the neophyte wearing a buekskin skirt painted red in stripes, and holding a bunch of yellow feathers in the hand. Details of this dance could not be obtained. In doctoring, the shaman was usually seated, and after singing for some time, sueked out the pain, which was generally a small, spindle-shaped object from one to two inches in length. The pain once extracted, melted away and disappeared in the shaman's hand.

Apart from the dance held by the shaman neophyte, and that already alluded to in speaking of the girls' puberty ceremony, the Chimariko seem to have had nothing exeept the so-ealled sweat-dance. This was a very simple affair, partieipated in by men alone, daneing without clothing and indoors. One member sang, and beat time on the ground with a stick. So far as could be learned, all the typical dances of the Hupa, Karok, and Yurok were wanting, and the Chimariko did not even attend them when held by the Hupa, as did the Shasta with the Karok.

In the summer time oceasionally people would hold the "round-danee" merely for pleasure. This consisted simply in a number of people dancing around in a eirele, without ornaments or paraphernalia of any sort, and was repeated as often as desired. It seems to have had little or no religious or ceremonial importance. 
Of the mythology of the Chimariko, only one or two fragments could be obtained. Coneerning the creation, it is said that the dog was the most powerful being. He knew everything beforehand, and told the coyote that a great wind was coming, which would blow all people away. He counselled the coyote to hold tightly to a tree, but when the wind came, the coyote whirled round and round, twisted the tree off, and blew away. Later the coyote returned, and the dog sang songs over him, and made him strong. The dog next prophesies a flood, and to escape it the two build a house of stone with an underground chamber. The flood comes, and all other people are destroyed, exeept the frog, mink, and otter, and one man. The flood subsides, finally, and the man finds a small fragment of bone in the eanoe in which the frog has taken refuge. This piece of bone he preserves in a basket, and it later comes to life as a girl child. The man marries the child, and from this pair all Chimariko are descended. There is possibly an element of missionary teaching in this tale, but it constitutes all that could be learned in regard to ideas of the origin of things.

The second fragment secured deals with a man who had two wives. Unsuccessful in hunting, he cuts off one leg and brings this back as game for the household. Next day he brings back his entrails and finally his other leg. The wives suspect what he has done and refuse to eat the meat, finally leaving him secretly while he sleeps, and running away.

There is finally a brief statement in regard to the securing of fire. The coyote suggests that all animals unite in an attempt to steal fire from the person who owns it. Several try to reach the place where it is kept, but give out before arriving. Finally Coyote himself tries, and succeeds in reaching the house, to find all away but the children. He outwits them, seizes the brand, and runs away. He is pursued by the father when he returns, and is almost caught, but throws the brand away, setting the whole country on fire, and thus escapes. In the fire the fox is burned red.

These tales do not show any close resemblance to any recorded from the Hupa or Wiyot, as representatives of the Northwestern Californian culture. As little relation appears to 
the tales known from the Wintun. With the tales from the Shasta there appears to be slightly greater similarity, although here the agreement is not at all striking. At best, however, these fragments do not offer very satisfactory material to judge from, and the most that ean be said is that what assoeiation there is, appears more clearly with the Shasta than with any other of the stoeks in the vicinity.

\section{CONCLUSIONS.}

From the foregoing account of the Chimariko, meagre though it is, we may draw eertain conclusions in regard to their general culture, and their relation to the surrounding eultures.

Living in close proximity to the Iupa, they nevertheless do not seem to have assimilated themselves at all closely to the Northwest Californian culture, of which the Hupa are representative. They feared the Hupa, and fought against them, allying themselves rather in sympathy and to some extent in eulture, with the Northern Wintun and the Shasta. Like the latter they lacked most of the distinetive features of both the Central and Northwestern Californian cultures, and seem to have occupied a kind of intermediate position between the two. In their material culture they were colorless, and this lack of any strongly marked characteristics is also apparent in their social organization and religious beliefs.

Any attempt to diseuss the past history or determine the movements of the Chimariko must be almost wholly speculative. On the one hand we may regard them as the remnant of a once much larger stock, subjeeted to pressure and attack on several sides, and so reduced to the small compass and unimportance which were theirs when discovered; on the other, we might perhaps assume from their cultural colorlessness and lack of close agreement with either the Northwestern or Central Californian cultures, that they are more closely affiliated with the Shastan stoek, which appears to have been pushing in a southsouthwesterly direction. With them also, as already stated, such resemblances as may be noted in the myths are most apparent. The two outlying dialectic groups of this stock, the Konomihu and the New River, apparently oecupy advance positions beyond 
the natural physiographic boundaries of the main area of the stock. Moreover, the language of the Chimariko shows in general greater similarities both formal and lexical, to the Shasta than to either the Hupa or the Wintun. These similarities, which are discussed in the linguistic portion of the paper, in fact are so numerous as to make it seem most likely that the two languages are genetically related. Further, it was among the Shasta, chiefly, that the remnants of the Chimariko took refuge when they fled from the Trinity River in the sixties. The paucity of material secured in regard to the Chimariko culture of course adds to the difficulty, and as usual in California, we get no aid here from any tradition of migration or earlier habitat. All things considered, the second of the above two suggestions appears the more reasonable, and we may conclude that, so far as the evidence goes, the Chimariko are to be regarded as related culturally most closely to the Shastan stock, and in origin probably forming part of it. Their historical affiliations therefore run northward and northeastward towards the interior of southwestern Oregon. 


\section{PART II. LANGUAGE.}

\section{INTRODUCTION.}

The material upon which the following sketch of the Chimariko language is based, was collected in the summer of 1906 on the New River, and at Willow Creek or China Flat, in Trinity County, California. The bulk of the material was obtained from Mrs. Dyer, probably the last full-blood Chimariko survivor, and from Friday, a man who, although not of Chimariko descent, yet spoke the language fluently, and had lived much of his life with the people. Owing to Mrs. Dyer's age and laek of teeth, she was not a very good informant, and some of the phonetic uncertainty is probably due to this faet. Previous to the writer's visit in 1906, short vocabularies and some grammatieal material had been collected by Dr. P. E. Goddard and Dr. A. L. Kroeber, in part from the same informants. This material has been placed at the author's disposal. The only other available souree of information on the language is Powers' vocabularies in his Tribes of California, and these have been used in connection with the more recent collection.

It is to be regretted that a larger mass of texts, and of a more satisfactory eharacter, could not have been secured, as these are so neeessary for a clear understanding of the language, and to eheck information obtained in other ways. It is felt, however, that the material here presented affords a reasonably eomplete sketch of the main features of Chimariko, although eertain details still remain obscure.

\section{PHONETICS.}

The vowel sounds oeeurring in Chimariko are i, e, a, o, u. As a rule the vowels are not short enough to be obscure, the only exeeption being in the the ease of e, written $\mathrm{E}$ when obscure. Doubling of vowels or their extreme length, particularly in the ease of a and $o$, is not uneommon, and the language is apparently 
fond of combinations of two vowel sounds, separated by ', a faint glottal catch. The sound of $\ddot{0}$, although occurring, is not common. There is some doubt as to whether long open è should not be written ä. A broad a or open o sound resembling English aw has been represented by â. Of all the vowel sounds, a is by far the most frequent. Nasalized vowels do not occur, and the infrequency of $\ddot{a}$, $\ddot{o}$, and $\ddot{u}$, so common in the adjacent languages, as for instance the Shasta, is noticeable. The vowels may be represented as follows :

$\begin{array}{llll}\bar{i} & \text { i } & & \\ \bar{\theta} & \theta & \grave{\theta} & \text { E } \\ \bar{a} & \mathrm{a} & \hat{\mathrm{a}} & \\ \bar{o} & o & \grave{o} & \\ \overline{\mathrm{u}} & \mathrm{u} & & \end{array}$

In the consonants, the sonant group is somewhat more developed than the surd. A true b seems to be lacking, although an intermediate sound, between surd and sonant, occasionally occurs. Of the two sonants $\mathrm{g}$ and $\mathrm{d}$, neither is common initially, the latter perhaps never so occurring, and generally being found in combination with $\mathrm{n}$ as $\mathrm{nd}$. The velar surd stop $\mathrm{q}$ is of moderately frequent occurrence, but its corresponding sonant is absent. Nasals are represented only by $n$ and $m, \tilde{n}(n g)$ being absent. The surd 1 sounds common in the languages adjacent, are absent, although ordinary $\mathbf{l}$ is common. There are apparently two $\mathbf{r}$ sounds. Besides the ordinary, rather strongly trilled $r$, there is a velar or uvular $r$, almost equivalent to spirant guttural $\mathrm{x}$. T followed by $\mathbf{r}$ seems to be a sound similar to tc, as one was often written for the other. A single instance of the use of an interdental, $\theta$, has been noted. The consonants in Chimariko may be shown as follows:

$\begin{array}{lllll}\mathrm{q} & & & \mathrm{x} \\ \mathrm{k} & \mathrm{g} & \mathrm{k}^{110} & & \\ \mathrm{t} & \mathrm{d} & & \mathrm{s}, \mathrm{e}(=\mathrm{sh}) \theta^{10} & \mathrm{n} \\ \mathrm{p} & \mathrm{b} & & \mathrm{m} \\ \mathrm{ts}, \text { te } & \mathrm{dj} & & \\ & & \mathrm{l}, \mathrm{r}, \mathrm{r} & \\ & & \mathrm{y} ; \mathrm{w} ; \mathrm{h}, \text { '; }^{\prime} & \end{array}$

$10 \mathrm{It}$ is not certain whether $\theta$ represents a stop or a spirant. Several California languages possess a $t$ whose interdental quality causes it to resemble English th. The character ', whether following $\mathbf{k}$ or another sound, indicates aspiration. 


\section{INITIAL SOUNDS.}

Although all the simple vowels ocenr initially, e and especially $o$ are rare, a being by far the most eommon. The tendeney for words to begin with vowels is only moderately strong, perhaps one-fourth falling into this elass. Of the semi-vowels, $y$ is initial but rarely. Of the consonants, $\mathrm{g}, \mathrm{d}, b$, and $\mathrm{r}$ do not oceur initially, and $l$ and $n$ are rare. The most frequent initial eonsonants are h, k, q, te, x, p, s or e, m, t. Syllables begin most usually with a consonant or double eonsonant.

\section{TERMINAL SOUNDS.}

All vowels except o have been found to oceur finally, $u$ and $e$ however being rare, and a by far the most eommon. Vowels are terminal sounds in perhaps three-fourths of the words noted. Of eonsonants, the only ones which rarely appear finally are $b$, $\mathrm{q}, \mathrm{x}$ and $\mathrm{h}$. The most common are $\mathrm{n}, \mathrm{r}, \mathrm{l}$, and $\mathrm{t}$. Syllables very frequently end in a eonsonant, and the typieal monosyllabie stem is formed of either consonant-rowel, or eonsonant-voweleonsonant.

\section{DIALECTICAL DIFFERENCES.}

In one point the material secured from the informant Friday differs rather regularly from that obtained from Mrs. Dyer. Very generally 1 was used by the former, where $r$ was heard from the latter. There was also a less frequent substitution of $\mathrm{s}$ for e. The faet that Mrs. Dyer had but very few teeth may in part aecount for these differences, but in not a few eases the same person would speak the word sometimes with $r$ and sometimes with l, or the sound would be very doubtful, as between the two. ${ }^{11}$ The diffieulty was most noticeable where the sound was terminal. It is possible that there may have been a real dialeetic difference, but the opportunity of determining this point with any eertainty was lacking, owing to the fact that Mrs. Dyer represents one of the two last surviving members of the stoek, and Friday is not a native Chimariko.

11 This was also the experienee of Dr. A. L. Kroeber, who at times found difficulty in distinguishing $d$ from $l$ and $r$, though he states that Friday frequently spoke l where Doetor Tom, another informant, used r. 


\section{COMBINATIONS OF SOUNDS.}

Combinations of vowels are frequent, and several diphthongs are in use, as ai, ei, oi, öi, au and eu. Consonant combinations occasionally occur at the beginning, and less frequently at the end of words, the initial combinations noted being tq, tx, trx, $\mathrm{px}$, sr. Combinations of two consonants within words are very common. In such combinations there is wide latitude as a whole, although the following restrictions may be noted. Both $q$ and $x$ are unknown as initial members of combinations. Of the sonants $b, \mathrm{~d}$, and $\mathrm{g}$, the first is never, and the others very rarely first members, and the labials are also, as a rule, unusual in this position. Combinations of three consonants are not wanting, the following having been observed: $n t x, n d r, m t x, m p x$, trq. Combinations of consonants at the beginning of syllables occur quite frequently, tr, tx, tex, $\mathrm{kl}, \mathrm{km}$, and px being the most common.

\section{INFLUENCE OF SOUNDS ON ONE ANOTHER.}

Chimariko is in accord with many of the languages of Northern Central California, in that there is little apparent modification of sounds through juxtaposition. There is a slight tendency for the connecting vowel between the pronominal prefix and the instrumental prefix, or the pronominal prefix and the verbal stem, to show some relationship to the vowel of the stem. This is, however, noticeable only in the case of $o$ and $u$ and perhaps a stems. In these cases, the connecting vowel is either the same as that of the stem, or near it in the regular vowel series. Such instances are retroactive. In other cases, the influence is proactive, the vowel of the negative prefix being assimilated to the vowel of the pronominal prefix, where this changes in the first person plural, as tcaxawini, I am old, tcoxowini, we are old. So far as consonants are concerned, euphonic and other changes in sound are not of very common occurrence. The following are the more important of those noted. $K$ is sometimes softened to $x$, owakni becoming owaxni, and is generally elided before $\mathrm{x}$, as in yeta $(\mathrm{k})$ xani, I shall sing. One instance occurs where $\mathrm{x}$ is replaced by w: ixusni, I blow, qowusni, ye blow. For euphony, $\mathrm{m}$ is sometimes inserted after a before $\mathrm{d}, \mathrm{x}$, or $\mathrm{g}$. In some cases, 
$\mathrm{g}$ changes to $\mathrm{x}$ after te. There are a number of instances where one stem-consonant may be replaced by another without apparent change of meaning, as : mum, muk; sum, sux; sim, six; am, ak ; teut, tcuk; pen, hen; pat, hat. In these cases $t$ and $m$ are replaced by $\mathrm{k}$ or $\mathrm{x}$, and $\mathrm{p}$ by $\mathrm{h}$. Contraction occurs not uncommonly, as in yaatciman for yayatciman; nateidut for noatcidut; -wax, -wak, -wok, -wauk for -watok.

\section{SUMMARX.}

In general Chimariko may be said to be simple and regular in its phonetics. It is not so smooth and soft as are Maidu, Wintun, and Yana and some other languages of the Central Californian area, but is considerably more so than the Shastan languages, and those of Northwestern California. The relative absence of sonants and spirants, and of velars and laterals, is characteristic. The considerable frequency of consonant combinations renders the language less transparent in structure than the Maidu or Wintun, but the slight degree of phonetic modification saves it from any considerable obscurity.

\section{REDUPLICATION.}

As compared with some of the adjacent languages, Chimariko makes comparatively little use of reduplication. Employed little if at all as a grammatical form, it occurs only sparingly in the names of a few birds, animals, and plants. In the case of the bird names, most, if not all, show clearly onomatopoeia. Color adjectives, it is interesting to note, do not appear to be reduplicated. The following cases of reduplication have been noted:

$\begin{array}{ll}\text { a'a, deer } & \text { himimitcei, grouse } \\ \text { pipilla, chipmunk } & \text { lâlo, goose } \\ \text { tsokokotci, bluejay } & \text { tcèitcèi, buzzard } \\ \text { xaxatcèi, duck } & \text { tsadadak, kingfisher } \\ \text { yekyek, hawk. } & \text { hutatat, crane }\end{array}$

\section{COMPOSITION}

Investigation of the processes of composition and derivation for purely etymological purposes, does not reveal a very extensive use. The following cases illustrate the principle examples noted : 


\section{āqa, water}

āqa-qot, àqa-kat, river ("at the water"'q)

aqa-rēda, aqa-tceta, ocean (probably "water-large")

aqa-xatsa, spring, "water-cold"

apu-n-aqa, "fire-water," whiskey

teitci-āqa-i, "'manzanita-water," cider

aqa-mateitsxol, water-fall, "water-dust",

asi-n-alla, sun, day-sun

himi-n-alla, moon, night-sun

hì-pxa, intestine

hi-pxa-dji, skin, bark

ama, earth, place, country

ama-yāqa, sand

ama-idatci-ku, nowhere

ami-texamut, earthquake

wee, antler

wee-naqalne, spoon

tïra, di 'la, bird

tīra-cela, teila-teele, blackbird

-sot, eye

-so-xa, tears (eye-water?)

-sot-nimi, eyebrow

-su-nsa, eyelash

xuli, bad

xuli-teni, left hand

hō-akta-xoli-k, lame

hisi-kni, good

hisi-deni, right hand

-kos-, to blow

i-kos-eta, wind

apu, fire

apu-n-aqa, fire-water

apu'-natxui, fire-drill base

apo-tcitpid-aktca, smoke-hole

tcim-ar, person, Indian

tcim-tukta, white man

acot-n-o-umul, "winter-salmon,", steelhead

umul-itcawa, "salmon-large," sturgeon

pa, to smoke

onī-pa, pipe 


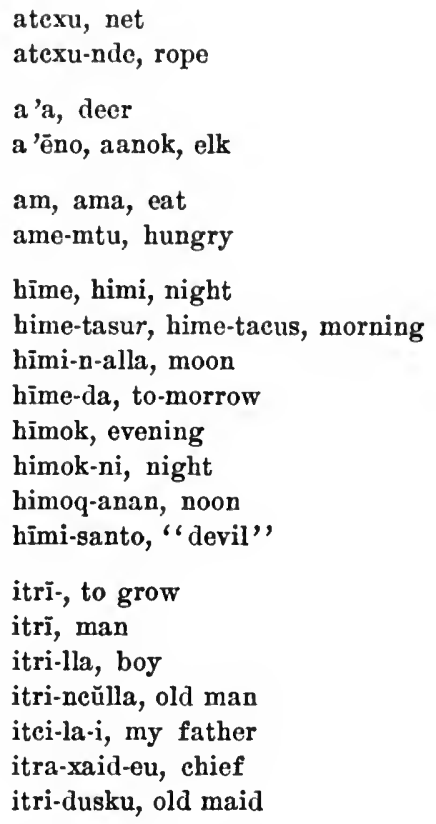

Other instances appear in the Chimariko-English vocabulary, in which derivatives are grouped under stems. Compare there, for instance, tcemu, sky, tca, hand, txa, leg.

In several of the above instances, an -n- appears between two nouns that are joined in composition: apu-n-aqa, asi-n-alla, himin-alla, acot-n-o-umul.

Some verb stems are identical with body-part terms that execute the action of the verb.

cam, sem, ear, or to hear

tu, wing, feather, or to fly

pen, tongue, or to lick

Derivation is by suffixes, of which the most important are:

-alla, -ulla, -olla, diminutive, especially on names of animals:

xar-ǔlla, xal-ala, baby

tcitcam-ŭlla, apxantc-olla, fox

hēmox-ola, jack-rabbit

ipūit-ella, bluebird

itr-illa, boy

itrine-ǔlla, old man

cunh-ŭlla, old woman 
punts-ŭlla, girl

ōěl-ulla, bachelor

o-ělla-i, my son

mas-olla-i, my daughter

itc-illa-i, my father

mag-olla-i, my uncle

teisum-ulla, orphan

pāsindjax-ola, water-ousel

pip-illa, wis-illa, chipmunk, beaver ( $($ )

poq-ella, cooking basket (pok, to wash)

citc-ella, sitc-ela, dog (citc-iwı, wolf)

cid-ulla, a spring

tumtit-ella, swallow

aw-illa, who (?)

maidjahutc-ulla, Yocumville

-na, tree, wood, stick, bush, plant:

apü'-Ena, fire-drill, lit. fire-wond

axac-na, puktcā-Ena, chaparral

ètxol-na, madrone

haqēw-ina, sugar-pine (haqēu, the cone)

hau-na, tinder

hawu'-una, grass

hepūitci'-ina, live oak

kīpi'-ina, fir

mūne'-Ena, black oak (muni, the acorn)

mutuma-na, redwood (mutuma, canoe)

qapu-na, deer brush

ipxadji'-ina, trūpxadji'-ina, maple

paktō'-Ena, alder

tèutèu-na, fern

tseli-na, gooseberry bush

tcimia-na, serviceberry bush

teitca-na, manzanita

tsuna-na, digging stick

xaxec-na, poison oak

yaqā-na, white oak

yutxū-ina, tan-bark oak

-eu, forms nouns from verbal stems:

aqed-eu, wild oats

ahat-eu, dentalium

axād-eu cat's cradle

hā'-eu, mortar basket

haq-eu, sugar-pine cone

hām-eu, food (am, ama, eat)

habukēd-ēu, slave

hekot-ēu, tattoo

hiěktcand-eu, woman's skirt

hitcumūdad-ehu, cup and ball game

ho'-eu, board 
hohankut-eu, fish spear

hâp-ēu, acorn soup

hâsunwed-eu, spear

isekdād-iu, tongs

itraxaid-eu, chief

petson-eu, grass-sced

trĕmamutc-eu, thunder

teen-eu, acorn-bread

trun-eu, belly

xâpun-eu, bow

-ktca, -uktca, -gutca, instrument or object for. As all the forms obtained begin with a vowel or $h$, it seems that they contain the pronominal prefix of the third person.

apo-tcitpid-aktca, smoke-hole

atcib-uksa, arrow-flaker

haim-uksa, ham-ukteu, ax

hamamē-gutca, fish-line, hook

hāma 'an-aksia, table (ama, eat)

hatciinar-utsa, bed

hax-aktca, deer trap

hěmuim-ektsa, split stick rattle

hēuma-kutca, grass game

hiäsmai-gutca, paddle

himì-gutca, sling

himīnid-uktsa, red lizard

hipun-aktca, button

hisūsamd-aksia, window

hiuxi-gutca, saw

hiwoanad-atsa, chair

hose-ktca, hâsus-akta, quiver

hâtsi-ktca, fire-drill (hatsir, make fire)

hâtsi-na-ktca, cedar (-na, wood)

ixa-gutca, thief

ixod-akta, clock

opum-aktca, storage basket

-ar:

tcim-ar, man

punts-ar, woman

at-ar, fish-spear (at, to hit)

kos-ar, crane

Perhaps also:

tsat-ur, grasshopper (tsat, fishweir)

akwec-ur, gray squirrel

tsabok-or, mole

pis-or, quail

himetas-ur, morning

$-x o l,-x a l,-x u l$ :

matcits-xol, or matre-pa, dust

aqa-matcits-xol, waterfall 
pate-xal, cocoon rattle

t'amite-xul, red ant

pētc-xol, hawk

sap-xel, spoon

èt-xol-na, madrone-tree

-tcei, on names of animals, especially birds. The syllable preceding the suffix is usually reduplicated, and therefore probably often onomatopoetic:

himimi-tcei, grouse

xaxa-tcei, duck

tcukuku-tcēi, owl

konana-tcēi, woodpecker

trēlek-tcēi, humming-bird

tsokoko-tei, blue-bird

ĕxoi-tcei, otter

qèpxami-tcèi, fisher

qērek-tcei, humming-bird

-tada, suffix of tribal names:

maitrok-tada, Hyampom people

qataidüwak-tada, Arcata Wiyot

hâdinaktco-hâda, Cedar Flat, a place (hâtsinaktca, cedar)

$-d j i,-d j e$, local suffix:

āqi-tce, Salt Ranch (aqi, salt)

tsūdamda-dji, Burnt Ranch

paktōna-dji, Patterson's (paktō'Ena, alder)

maidjatcū-dje, Cecilville (maitra, a flat or bench)

hītūai-dje, Willow Creek

and many others given in the list of place names in the vocabulary.

-ma, - $m u$, on place names:

tcitcan-ma, Taylor's Flat (tcitca-na, manzanita)

teintxap-mu, Big Flat (tcintcei, sun-flower)

tranqo-ma, Hyampom

hisaē-mu, Weaverville

-matci, on names of seasons:

ahan-matei, summer

kicu-matei, spring

kicu-matci, spring (kisum, crane)

qâ-suk-matci, when

-ckut, privative:

aquye-ckut, tail-less

itra-ckut, handless

hu-po-ckun, footless

puntsarie-ckut, wife-less, bachelor

itri-d-usku, old maid

$-g u,-k u$, negative; perhaps also indefinite:

xanī-gu, by and by

curai-gu, some time ago (sul, long ago)

patceam-ku, something (patci, what)

patci-gun, no

amaidatci-ku, nowhere 
$-d a$, on terms of direction:

wise-da, down-strean

wai-da, up-stream, east

qadai-da, south

xunoi-da, north

tcem-da, across stream

tranmi-da, down-stream

Possibly also:

hime-da, to-morrow

$-' i$, on terms of color and other adjectives, both syllables of the stem showing the same vowel:

tcele- 'i, black

mene-'i, white

wili-'i, red

söte'-i, blue ( 9 )

tono'-i, dull

mata-'i, clean

cupu-i, sharp

$-i n,-n$, $-n i$, on adjectives, is evidently the verbal suffix indicating present or incompleted action:

atcxum-ni, dry

elox-ni, hot

hadoha-n, straight

hēmudadja-n, bitter

hiquii-ni, sweet

hisik-ni, good

hitcu-n, hiteū-eni, long, high

hoqatā'-Eni, square

hukēna-n, deaf

hutcolana-n, empty

hutcula-n, low

quoyo-in, sour

kumitc-in, all

lo 'ore-n, soft

lūyu-in, smooth

nodaduh-ni, rough

pepe-'in, thick

p'qele-'in, crooked

tqe'er-'in, thin

tcele-'in, dirty

tcuxunm-in, deep

texale-n, light

xē'ire-n, xerē'-in, narrow, wide

xodala-n, poor

xuitcula-n, short

For grammatical purposes, affixation is chiefly used. The following list of affixes comprises those which have been determined with any certainty : 


\section{Pronominal:}

\section{A. PREFIXES OR SUFFIXES.}

te, first person singular. Prefixed or suffixed as subject of intransitive verbs, with adjectival stems. Prefixed as object of transitive verbs. Prefixed as possessive, with nouns where possession is inherent.

i, y, first person singular. Prefixed or suffixed as subject of intransitive verbs, with verbal stems. Prefixed as subject of transitive verbs. Suffixed as possessive with nouns where possession is accidental.

$\mathrm{m}$, mi, second person singular. Prefixed or suffixed as subject of intransitive verbs. Prefixed as subject or object of transitive verbs, or as possessive with nouns where possession is inherent. Suffixed with nouns where possession is accidental.

n, second person singular. Imperative. Prefixed.

h, ', third person singular and plural. Prefixed (as h) or suffixed (as ${ }^{\text {) }}$ ) as subject of intransitive verbs. Prefixed as possessive with nouns where possession is inherent.

tea, tco, first person plural. Prefixed or suffixed as subject of intransitive verbs, with adjectival stems. This suffix is distinguished from singular te- by change of vowel. If the singular has a as connecting vowel, the plural has 0 , and vice-versa. Prefixed as object of transitive verbs.

tce, first person plural. Suffixed with nouns where possession is accidental.

ya, we, w, first person plural. Prefixed or suffixed as subject of intransitive verbs, with verbal stems. Prefixed (ya-) as subject of transitive verbs.

q, qo, qe, second person plural. Prefixed or suffixed as subject of intransitive verbs. Prefixed as subject or object of transitive verbs. Suffixed as possessive with nouns where possession is accidental.

Affix used with verbal stems:

$\mathrm{x}, \mathrm{g}, \mathrm{k}$. Negative affix, with variable connecting vowel. Used either as prefix or suffix, or both.

\section{B. PREFIXES.}

Instrumental, with verbs:

$\begin{array}{ll}\text { a- } & \text { with a long object } \\ \text { e- } & \text { with the end of a long object } \\ \text { ma- } & \text { with the head } \\ \text { me- } & \text { with the foot } \\ \text { mitei- } & \text { with a round object } \\ \text { tc- } & \text { with the hand } \\ \text { teu- } & \text { by sitting on (q) } \\ \text { tu- } & \end{array}$




\section{SUFFIXES.}

With pronominal stems :

-owa

With nominal stems:

Loeative, instrumental.
-dan, -danku
ablative
-mdi, -mdu
instrumental

Miscellaneous.

$\begin{array}{ll}\text {-hni } & \text { many } \\ \text {-tan } & \text { many } \\ \text {-rotpin } & \text { only a, just a } \\ \text {-gulan } & \text { merely, only (Cf. negative affix -g) } \\ \text {-abo } & \text { also, too }\end{array}$

With verbal stems:

Ideas of motion or direction.

$\begin{array}{ll}\text {-dam, -tam, -ktam } & \text { down } \\ \text {-Ema } & \text { into } \\ \text {-Enak } & \text { into } \\ \text {-ha } & \text { up } \\ \text {-bot } & \text { down } \\ \text {-lo } & \text { apart( ( ) } \\ \text {-mi } & \text { down( ( ) } \\ \text {-puye } & \text { around, about } \\ \text {-ro } & \text { up } \\ \text {-sku } & \text { towards } \\ \text {-smu } & \text { aeross } \\ \text {-tap } & \text { out } \\ \text {-tpi } & \text { out of } \\ \text {-usam } & \text { through } \\ \text {-xun } & \text { into }\end{array}$

Modal, temporal.

-ak

$-n$, -ni, -in

-sun

-xan, -gon

-soop

-dialhin

-hun

-pum

-wet

-tcai

-eyè

-ye

completed action, past

incompleted action, present

present. Used apparently as the auxiliary verb to be.

future. (Former with verbal, latter with adjectival stems.)

conditional

dubitative

continuative

iterative

continuative

desiderative( 9 )

reflexivo

interrogative 


\author{
-a interrogative \\ -pu interrogative \\ -da, -ida, -inda, -tinda present participle \\ Miscellaneous. \\ -tei \\ -nan, -an \\ Used to indicate plurality, generally of the \\ object, but occasionally of the subject. \\ A general verbal suffix of uncertain meaning, \\ possibly temporal (Cf. -ni, -in).
}

With all classes of stems :

-ot, -ut, -op

A suffix apparently with an intensive, or emphatic meaning, such as indeed, really, in truth. It is used with nominal, pronominal, verbal, adjectival, and adverbial stems.

The above list brings out clearly several features of importance in regard to the Chimariko language. In the first place, it will be seen from the series of pronominal affixes, that these are by no means regular in position, appearing sometimes as prefixes, sometimes as suffixes. It is possible that in some cases they are also used as infixes. This variability of position of the pronominal elements with regard to the verbal stem is a feature also found developed among the Shastan languages, which adjoin Chimariko on the north, and differentiates these two languages from those which, like Washo, Chumash, Southern and Northeastern Maidu, have the pronominal elements in an invariable position. Although there seems to be a strong preference for prefixation, there are yet a large number of verbs which take the pronoun suffixed. No logical reason is apparent for the distinction, such verbs as to sit, to work, to dance, to run, to eat, and others, prefixing the pronominal elements, whereas to bleed, to grow, to die, and so on, take them suffixed. The lack of any logical division is shown still more clearly in the verbs indicating condition or state. Some, as to be good, to be bad, to be old, have the pronominal elements prefixed; others, as to be hot, to be cold, to be strong, suffix them. Dry belongs to the first class, and wet to the second. The employment of varied position in the pronominal affixes, to indicate two forms of possession, is interesting. Where possession is inherent, the elements are prefixed, where accidental, suffixed.

A further feature brought out by the list, is the great paucity 
of nominal suffixes. Chimariko not only lacks such indications for grammatical eases and for number, but also is almost destitute of locative endings. An instrumental suffix it has, to be sure, but of locatives the only one noted is an ablative; there is apparently no general locative. In this paucity of loeative suffixes, Chimariko lies at the other extreme from the majority of the languages of Central California, which possess a considerable development of this elass of suffixes. Even the neighboring Shastan languages, although having fewer locatives than Maidu and Washo, still exceed Chimariko in this particular.

The considerable development of verbal instrumental prefixes, places Chimariko in this respect in agreement with Washo, Maidu, Wintun, and the Shastan languages. As is usual, the suffixes of motion precede those which are modal or temporal. In general, the large preponderance of suffixes over prefixes places Chimariko in the elass of suffixing languages.

An interesting feature of the language is presented by the emphatic or intensive suffix -ut, -ot. It is used with the pronominal stems to form the independent pronouns, which are rarely used except for emphasis, or where the sense is doubtful. These may therefore be translated I indeed, I myself, and so on. With nouns, this suffix is used generally to mark either the subject or the object as the most important in the sentence, as, eitcela hitratinda puntsal-ot, the dog bit the woman (not man); ūmul-op yekotpumni, salmon (not deer) I kill. In some cases, euriously, it is used with both subject and object, and in others entirely omitted. With verbs, its purpose is similar, to emphasize the verbal idea above any other in the sentence, as, teimal-ot hititcex-ot pusūa man broke (not cut, burned) the stick. With adjectives and adverbs it also intensifies the idea contained in the word to which it is added, as, qa'a trēwil-ot nahak, stone large bring me; citel-op yekoxan himet-op, $\operatorname{dog}$ I will kill to-morrow.

\section{PRONOUN.}

Chimariko, differing from a large number of languages in California, belongs to the elass of incorporating languages. There are thus two forms for the personal pronoun, the independent and the incorporated. 


\section{INDEPENDENT PERSONAL PRONOUN.}

In general, as already stated, the independent form is rarely used. A complete paradigm can not be given, as it proved impossible to get from any of the informants the second and third persons plural, they invariably using either the numeral two, or some word equivalent to many or several. So far as obtained the forms are as follows:

$\begin{array}{cccc}\text { Singular. } & \text { Dual. } & \begin{array}{c}\text { Plural. } \\ \text { natcidut }\end{array} \\ \text { 1. } & \text { nōut } & \begin{array}{l}\text { nōtowa (excl.) } \\ \text { mamutowa (incl.) }\end{array} & \\ \text { 2. } & \text { mamut } & & \\ \text { 3. } & \text { hamut } & & \end{array}$

It will be seen that, as in so many American languages, the pronominal stems of the first and second persons are based on $n$ and $\mathrm{m}$. The independent forms are derived from the stems nōand mam- by the addition of the emphatic suffix -ut. The form given for the third person is only rarely used, a demonstrative form, pamut, paut, pât, generally taking its place. Although the material secured is not entirely clear on this point, it is probable that there are, in addition to a simple plural formed by the addition of what is apparently a plural suffix -ate, also both an inclusive and exclusive form, derived from the first and second persons singular. On the other hand, it is possible that these two forms are really the first and second persons dual.

\section{DEMONSTRATIVES.}

Two demonstratives are known with eertainty. These are formed with the stem qè-, near the speaker, here; and pa-, at a distance, there. These stems take the intensive suffix -ut, becoming thus qèwot, qât, this, and pamut, paut, pât, that.

\section{INTERROGATIVES.}

The interrogative pronouns are derived mainly from a single stem qo-, qâ, and are as follows:

$\begin{array}{ll}\text { qomas or awilla } & \text { who } \\ \text { qâtci or pātci } & \text { what } \\ \text { qomalla } & \text { where } \\ \text { qosidadji } & \text { why } \\ \text { qâsuk } & \text { when } \\ \text { qâtala } & \text { how many } \\ \text { qâteu } & \text { how far } \\ \text { qâtramdu } & \text { how often }\end{array}$




\section{NOUN.}

\section{CASE SUFFIXES.}

As might be expected from its being an incorporating language, Chimariko shows no trace of any syntactical cases. Locative and instrumental suffixes are largely lacking also, their place being taken in part by a small number of postpositions. The suffixes of locative or instrumental meaning derivable from the material at hand are only two:-dan, -danku, a general locative or more commonly ablative, and -mdi, -mdu, instrumental.

\section{NUMBER.}

Number is not indicated in the noun, and no variation for number is made when nouns are used with numeral adjectives. There are, however, two suffixes sometimes used to indicate a collective. These are -hni and -tan, as in qa' 'ahni, a lot of stones, many stones; itritan, a erowd, a lot of men. The latter suffix seems to be a shortened form of hètan, many.

\section{POSSESSIVE.}

The possessive is formed by affixing to the noun the proper pronominal stem. Two classes of possession are recognized, accidental and inherent. In the former, the pronominal elements are always suffixed, and are -i, -mi, -ye, -ida,- tce, -qe, -ye, -ida; in the latter they are always prefixed, and are te-, m- h-. It will be seen that the same form of the pronominal element is used thus for inherent possession as is employed in intransitive verbs with stems indicating a quality or condition. Quality or condition may thus be thought of perhaps as more inherent in the subject than are motion or action, on stems denoting which the same pronominal elements are used as to indicate accidental possession. Examples of the use of the two forms are:

Accidental:

$\begin{array}{llll}\text { masomas-i } & \text { my red-salmon } & \bar{a} w a i \text { '-i } & \text { my house } \\ \text { masomas-mi } & \text { thy red-salmon } & \bar{a} w a-m i & \text { thy house } \\ \text { masomas-ye } & \text { his red-salmon } & \bar{a} w a-i d a & \text { his house } \\ \text { masomas-itce } & \text { our red-salmon } & \bar{a} w a \text { '-itee } & \text { our house } \\ \text { masomas-qe } & \text { your red-salmon } & \bar{a} w a-q e & \text { your house } \\ \text { masomas-ye } & \text { their red-salmon } & \bar{a} w a-i d a & \text { their house }\end{array}$


Inherent:

teū-po

mū-po

hü-po

my foot
thy foot
his foot

tcū-sam

my ear

mì-sam thy ear

hì-sam his ear.

Some question arises as to the two forms used in the third person where possession is accidental. The suffix -ye seems to be merely the interrogative, often found in use with verbs, so that this form should be translated: "is it his?" The use of -da on the other hand offers much difficulty. This suffix is, in its uses, far from clear, although its normal force, as used with verbs, is participial.

\section{VERB.}

The discussion of the verb may best be taken up under two headings, first the various affixes used for syntactical or etymological purposes, and second the stem and such modifications as it undergoes.

\section{PRONOMINAL AFFIXES.}

First in importance are the pronominal affixes. As stated in speaking of the pronoun, the independent forms are rarely used, and the subject and subject-object relationship is expressed instead by incorporated forms.

In the intransitive, the pronominal affixes show some variety of form, and a rather puzzling irregularity of use. The affixes in question are as follows:

\section{Singular.}

1. te, $\mathrm{i}, \mathrm{y}$

2. $\mathrm{m}, \mathrm{mi}$

3. $\mathrm{h},{ }^{\mathrm{e}}$
Plural.

tc, ts, ya

q, qe

$\mathrm{h}$

As compared with the independent forms of the pronoun, it is evident that there is correspondence in the second and third persons, the first person being on the other hand entirely distinct. A further difference lies in the apparent absence, in the affixed form, of any distinction between inelusive and exclusive plurals. In use these pronominal elements seem normally to be prefixed, 
being so used in over seventy per cent. of the eases known. In the remainder of the instances they are suffixed, with one or two possible cases where they seem to be infixed. From the small number of instances of this latter usage, however, it is not possible to be sure that the syllable following the pronominal element is really a part of the verbal stem. What prineiple determines the use of one or the other of these positions is obscure, such verbs as sing, work, be good, be blind, taking the elements as prefixes, whereas grow, die, be hungry, siek, take them as suffixes. One distinction can however be made, namely that verbs indicating action or movement invariably take the pronominal affixes prefixed.

It will be seen that two wholly different forms are given in both singular and plural for the first person. In the use of one or the other of these, there is a fairly clear distinction in use. The first type, te, is never employed with verbal stems indieating action or movement, but with those, on the contrary, which indicate a state or condition. On the other hand, whereas the second form, i, y, is invariably used with the former elass of verbal stems, it is also employed with the latter, but is then always suffixed. In most cases, there is no confusion between the two forms, i.e., if the first person singular is $\mathrm{i}$ or $\mathrm{y}$, the first person plural is ya. A few instances appear however in which this does not hold, and we have $\mathrm{i}$ in the singular, and te or ts in the plural. In a limited number of cases also, either form may apparently be used, as qè-i-xanan, qè-tee-xanan, I shall die, $i$-saxni, tea-saxni, I cough. A phonetic basis is to some extent observable, in that te or ts is never a prefix when the verbal stem begins with a vowel. As between $\mathrm{i}$ and $\mathrm{y}$, it appears that the latter is always used before stems beginning with a vowel except $\mathrm{i}$, whereas $\mathrm{i}$ is employed before stems beginning with $\mathrm{i}$ or with consonants. The first persons singular and plural are distinguished from each other, where the form te is used, only by a change of connecting vowel already pointed out.

The pronominal elements as given, are, when used as prefixes, attached to the verb by means of connecting vowels. These, as stated in diseussing the phonetic characteristies of the language, 
often show some relation to the vowel of the verbal stem, $^{12}$ but this is noticeable chiefly in the case of $o$ and $u$ stems. The first persons singular and plural are distinguished from each other only by the change in this connecting vowel. As a rule, the first person singular is teo or teu, whereas the plural is tea. In one or two instances, however, this seems to be reversed.

The material collected to illustrate the use of the pronominal elements in the transitive verb, is unfortunately conflicting, and the lack of adequate text material here makes itself felt. In the transitive verb with nominal object the situation is clear enough. Here the pronominal elements used as subject are invariably prefixed, and are those used with the intransitive verbs indicating action or movement, i.e., the first person appears always as i, y, or ya.

Where the object is pronominal, however, the usage is different, as the following table will indicate:

\begin{tabular}{|c|c|c|c|c|c|c|}
\hline & $m e$ & thee & him & $u s$ & ye & them \\
\hline I & & $\mathrm{i}-$ & $\mathrm{i}$ - & & i-atci & q \\
\hline thou & mi-, me- & & mi- & $\mathrm{mi}$ & & $\mathrm{mi}$ \\
\hline he & tcu-, tca- & mi- & ? & tca-, ya- & qo-, qa- & $q$ \\
\hline we & & ya- & ya- & & ya- & ya- \\
\hline$y e$ & & & qo- & qo- & & ? \\
\hline they & teu-, tea- & mi- & ha- & tea- & qo- & ? \\
\hline
\end{tabular}

From this it is clear, that in the first and second persons, only the subject is expressed by a pronominal affix, and that the same form is used as with the transitive verb with nominal object. In the third person, on the other hand, it is the object rather than the subject which is expressed by the prefix, which here, in the

12 Much the same occurs in the possessive prefixes of the noun. The fol lowing are observed cases of the third person possessive on body part terms:

Vowel of prefix same as that of stem:

$i$ : hi-wi, hi-mina, hi-ni, hi-mi, hi-ki, hi-pel, hi-teipe, hi-pen.

$u$ : hu-truneu, hu-txun, hu-tsu, hu-tu, hu-sot, hu-po.

$a$ : ha-wa.

Vowel of prefix differing from stem:

$i$ : hi-ta, hi-tanpu, hi-sam, hi-wax, hi-ma, hi-pxa, hi-pxadji, hi-txa, hi-txanimaxa, hi-taxai, hi-suma, hi-mosni.

$u$ : hu-si, hu-santcei, hu-tananundjatun.

$o:$ ho-wec, ho-napu, ho-xu.

$e:$ e-qa, e-que.

It will be seen that the connecting rowel of the prefix contrasts with the stem about as often as it differs from it, but the principle determining the choice of vowel-which is definitely fixed for each word-is not clear. Conditions in the verb are generally similar. 
ease of the first person as object, is the other form, that namely in tc. In some eases, where the first or second persons are the subject, the independent form of the pronoun is used outside the verb to indieate the object. In other eases the independent forms were not used, leaving the meaning apparently obscure. To some extent Chimariko in this respeet resembles the neighboring Shasta, where also both subjeet and object are not always indieated by ineorporated pronominal elements. In Shasta, however, this loss of definiteness is atoned for by the wide use of demonstratives, which do not seem to be in use for the same purpose in Chimariko. In this eonnection should be mentioned the troublesome suffix -da, -ida, -inda, -tinda. This is frequently used with verbs, and was at first thought to be perhaps a demonstrative, but seems on the whole most probably to be simply the partieipial suffix -da, eombined with the suffix of the present tense, -in, -ni. Examples of the use of pronominal elements with verbal stems are given below.

$\begin{array}{ll}\text { Nominal object: } & \\ \text { i-mitcitni citcela } & \text { I kick the dog } \\ \text { mi-mitcitida citccla } & \text { You kick the dog } \\ \text { hi-mitcitni citcela } & \text { He kicks the dog } \\ \text { ya-mitcitni citcela } & \text { We kick the dog } \\ \text { qo-mitcit citcela } & \text { Ye kick the dog } \\ \text { hi-mitcit eitcela } & \text { They kick the dog } \\ \text { Pronominal object: } & \\ \text { i-mitcitni } & \text { I kick you } \\ \text { i-patni } & \text { I poke you } \\ \text { i-mamni } & \text { I see you } \\ \text { i-puimukni } & \text { I pinch you } \\ \text { i-mitcitinda } & \text { I kick him } \\ \text { i-patni pamut } & \text { I poke him } \\ \text { i-mamni } & \text { I sce him } \\ \text { i-puimukni } & \text { I pinch him } \\ \text { i-mitcitnatci } & \text { I kick you } \\ \text { i-patnãtci } & \text { I poke you } \\ \text { i-puimuknatci } & \text { I pinch them } \\ \text { me-mitcitida } & \text { You kick me } \\ \text { me-patni } & \text { You poke me } \\ \text { me-puimukni } & \text { You pinch me } \\ \text { mi-mitcitni } & \text { You kick him } \\ \text { mi-puimuk } & \text { You pinch him } \\ \text { mi-miteitida } & \text { You kick us } \\ \text { teu-miteitida } & \text { He kicks me } \\ \text { teu-hatni } & \text { He pokes me } \\ & \end{array}$




tcu-mamni
mi-mitcitni
mi-hatni, mi-hatinda
mi-mamni( ( )
tca-mitcitinda
tca-puimuk
tca-mamni
qo-mitcitinda
qa-hatni
hi-mitcitinda( ( )
ya-mamni
ya-mamni
qo-mama
qo-mama
tcu-mamtinda
mi-mamtinda

\author{
He sees me \\ He kicks you \\ He pokes you \\ He sees you \\ He kicks us \\ He pinches us \\ He sees us \\ He kicks you \\ He pokes you \\ He kicks them \\ We see you \\ We see him \\ Ye see me \\ Ye see him \\ They see me \\ They see you
}

A feature of considerable importance in the structure of the verb lies in the apparent use, although rarely, of nominal incorporation, and possibly of complete incorporation of both subject and object pronominal elements. In the texts as obtained occur the forms appexadjit and āpisuxta, translated respectively as "fire he steals" and "fire he throws away." The noun fire is $\bar{a} p u$, and the verbal stems -xadj, to steal, and -sux-, to throw, occur frequently without any such apparent incorporation of nominal object. As these are the only clear cases, nominal incorporation is hardly a characteristic of the language. The tendency toward such forms may however be seen also in the words for wink and to shake the head, (nu)sulaplap, (tcu)maitsat, the former incorporating the stem for eye (-sot-), the other that for head (-ma). A single instance of apparent incorporation of both subject and object pronominal elements occurs in the form ye-mam-i-xan, probably for ye-mam-mi-xan, I-feed (eat)-you-will, I will feed you. As the verbal stem here ends in $\mathrm{m}$, it is difficult to tell whether the $\mathrm{i}$ really stands for $\mathrm{mi}$ or is simply euphonic before the future suffix.

\section{REFLEXIVE.}

The reflexive is indicated by the use of the suffix -eye, -yiye, -èiyeu, added directly to the verbal stem, the prefixed pronominal elements being the same as those used with the intransitive verb.

i-tcut-èiyeu

mi-tcut-èiyeu

hi-tcut-èiyeuni pamut
I strike myself you strike yourself he strikes himself 


\section{IMPERATIVE.}

The imperative is indicated in the singular by a prefix n-, which always takes the same eomnecting vowel between it and the verbal stem as the second person singular indicative. The verbal stem is in most cases used without suffix of any sort. For the exhortative "let us" the prefix of the first person plural, $y-$, ya-, is used, the verbal stem being similarly without suffixes.

$\begin{array}{ll}\text { na-tak } & \text { sing! } \\ \text { ni-miteit } & \text { kick him! } \\ \text { ni-puimuk } & \text { pinch him! } \\ \text { n-ama } & \text { eat! } \\ \text { ya-texuai } & \text { let us fight! } \\ \text { ya-traxismu } & \text { let us run! } \\ \text { y-amma } & \text { let us eat! }\end{array}$

\section{FORMATIVE AFFIXES.}

Apart from the pronominal and the modal and temporal elements, there are two elasses of affixes used with the verb. One of these is instrumental in meaning, the other is used to modify the idea of motion contained in the verbal stem.

Ideas of instrumentality, as that the action is performed by the hand, foot, end of a long thing, and so forth, are expressed uniformly by means of prefixes. This is in accord with the usual rule of American languages, and with the usage of three of the stocks which are in elose geographical proximity to Chimariko, the Shasta, Maidu, and Wintun. These instrumental prefixes are placed immediately before the verbal stem, and, so far as obtained, are as follows:

a-
e-
ma-
me-
mitei-
te-
teu-
tu-
wa-

Examples :

ni-a-axiaxe n-a-kluemu ni-e-kluemu with a long object

with the end of a long object

with the head

with the foot

?

with a round object

with the hand

by sitting on(?)

rub with long thing (side of 9 )

knock over with bat

knock over with end of pole by thrust 


ni-e-kmu
ni-me-kmu
i-me-kluemu
ni-mitci-kluemu
ni-mitei-kmu
ni-teu-klucmu
ni-tu-kluemu
ni-tu-kmu
ni-tu-xiaxe
ni-wa-tcexu

ni-e-kmu

ni-mitei-kluemu

ni-teu-kluemu roll log with end of pole roll log with head, by butting knock over with head, butt over knock over with foot, kick over roll $\log$ with foot

knock over with a stone, ball knock over with hand roll log with hand rub with hand break by sitting on.

Modifications of the idea of motion expressed in the verbal stem are indicated uniformly by suffixes, and not by prefixes. The meanings of some of these suffixes are not as yet wholly clear, and it is probable that the list could be extended by further material.

$\begin{array}{ll}\text {-dam, -tam, -ktam } & \text { down } \\ \text {-Ema } & \text { into } \\ \text {-Enak } & \text { into } \\ \text {-ha } & \text { up } \\ \text {-hot } & \text { down } \\ \text {-lo } & \text { apart( ( ) } \\ \text {-mi } & \text { down(?) } \\ \text {-puye } & \text { around, about } \\ \text {-ro } & \text { up } \\ \text {-sku } & \text { towards } \\ \text {-smu } & \text { across } \\ \text {-tap } & \text { out } \\ \text {-tpi } & \text { out of } \\ \text {-usam } & \text { through } \\ \text {-xun } & \text { into }\end{array}$

Examples:

$\begin{array}{ll}\text { nu-tu'-Ema } & \text { jump into } \\ \text { na-ar-ha } & \text { elimb up } \\ \text { wak-ti-he-inda } & \text { they travel about } \\ \text { ni-sâp-hot-mi } & \text { slide down roof } \\ \text { ni-tu-k-tam } & \text { roll down with hand } \\ \text { ni-te-xa-lo } & \text { pull out tooth } \\ \text { hu-tsut-min } & \text { he flies down } \\ \text { hu-tut-puye } & \text { he flies around } \\ \text { hu-tsu-sku } & \text { he flies toward } \\ \text { ni-tu-smu } & \text { jump across toward } \\ \text { hu-tsu-tap-ni } & \text { he flies out } \\ \text { nu-tu-tpim } & \text { jump out of } \\ \text { nu-tu-tusam } & \text { jump, run under } \\ \text { ni-tcuk-xun-mi } & \text { hammer into down (a nail) }\end{array}$




\section{TEMPORAL AND MODAL AFFIXES.}

As in the ease of the last group, ideas of tense or mode are uniformly expressed by suffixes, and these suffixes invariably follow any suffixes of motion where these are used. In the case of the future, the suffix follows the verbal stem or suffixes of motion when the pronominal element is prefixed, but comes after the latter in those eases where it is suffixed. In addition to those here given, there are several suffixes of whieh the meaning is still obseure.

$-n i,-n i n,-i n$, present, incompleted action:

$\begin{array}{ll}\text { i-mam-ni } & \text { I see you } \\ \text { tcu-kèi-ni } & \text { he hears me } \\ \text { södrè-i-ni } & \text { I bleed }\end{array}$

-sun, present. Used apparently as the auxiliary verb to be.

$-a k,-k$, past, completed action:

amemtuin-ak

ya-hadan-ak

ecomdum-qa-te-ak-cur

I was hungry

we were rich

ye were cold then

-gon, -xan, future:

pala-tce-gon

amemtu-tce-gon xani

ye-hada-e-gon

yo-wam-xanan

hi-mum-han

we shall be strong

I shall be hungry by and by

I shall be rich

I shall go

he will run

ye-ko-xanan

I shall kill him

$-d a,-i d a,-i n d a,-t i n d a$, present participle:

puntsari-da anowesta itrila

imim-da i-txa-Eni

woman-being she whipped boy

i-mam-ni samxun-ida

I stop running (running I stop)

hi-samxun-inda ye-ko-n

I saw him dancing

I kill him while dancing (dancing I kill)

qo-xowin-tinda

i-mitcit-inda

ye being old, ye are old

I (am) kicking him

$-y e,-e$, interrogative:

ma-ko-ye

are you going to kill me?

mi-ke'e-ye

do you hear me?

-soop, conditional:

mi-mum-soop ye-nuwec-xan

if you run, I shall whip you

himeta hitak-soop yu-wam-xan qè-soop

if it rains to-morrow, I will go

if (I) should dic.

-dialhin, dubitative:

qe-te-ok-dialhin

perhaps I shall be sick (sick-I-perhaps)

mi-miteit-dialhin

you kiek he may (he may kick you) 


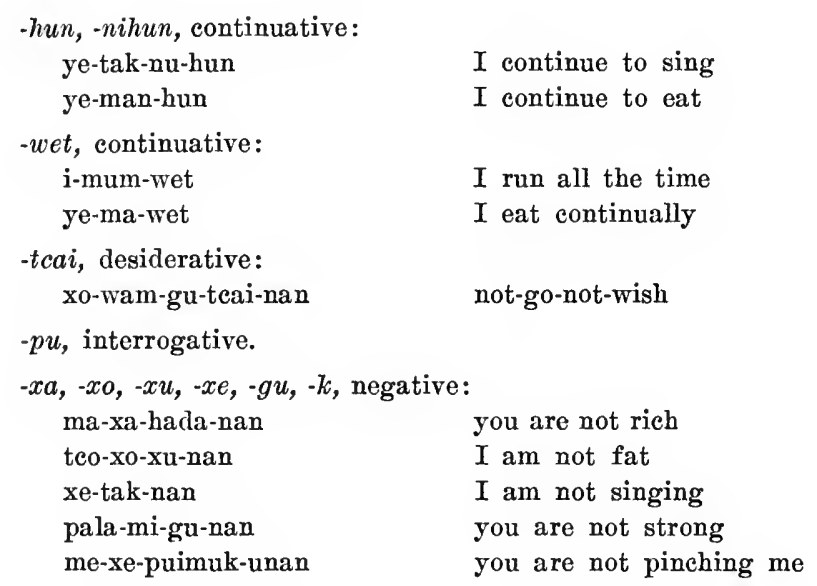

The negative is expressed in two ways, according as the pronominal elements are prefixed or suffixed to the verbal stem. In the former case, a prefix xa-, xo-, xe- is placed between the verbal stem and the pronominal element, and a suffix -nan added after the verbal stem or such other suffixes as there may be. The essential element seems to be $x$, the connecting vowel varying with that of the pronominal element and the verbal stem. In the first person singular intransitive, it is generally xe-, and the pronominal element is omitted. Where the pronominal elements are suffixed, the negative affix is combined with -nan, and is placed as a suffix following the pronominal element, the $x$ being changed to $\mathrm{a} g$, and the connecting vowel sometimes dropping out, resulting in the form -gnan. In some cases, indeed quite frequently in the transitive verb, the negative affix appears twice, xo- or xu-preceding, and -gu following the verbal stem. Very commonly the apparently desiderative suffix -tcai is used with the negative, resulting in a form which may be translated "do not wish to."

\section{VERBAL STEMS.}

In a limited number of instances, a different verbal stem is employed in the plural from that in the singular. Not infrequently, however, informants, on giving such forms, on closer questioning admitted that the singular stem might also be used, and that the variant stem first given for the plural might be 
used also in the singular, i.e., the two stems were merely synonyms. Only two cases were found which did not appear to be explainable in this manner, and the second seems only to belong partly to this eategory, inasmuch as the distinction holds good only in the present tense.

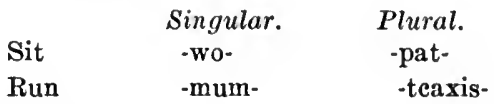

The verbal stems which have been isolated in the analysis of the material collected, are both monosyllabic and polysyllabic. Many of the latter are probably derivatives, but it has not been possible to analyze them as yet. The great majority of stems appear to be monosyllabic.

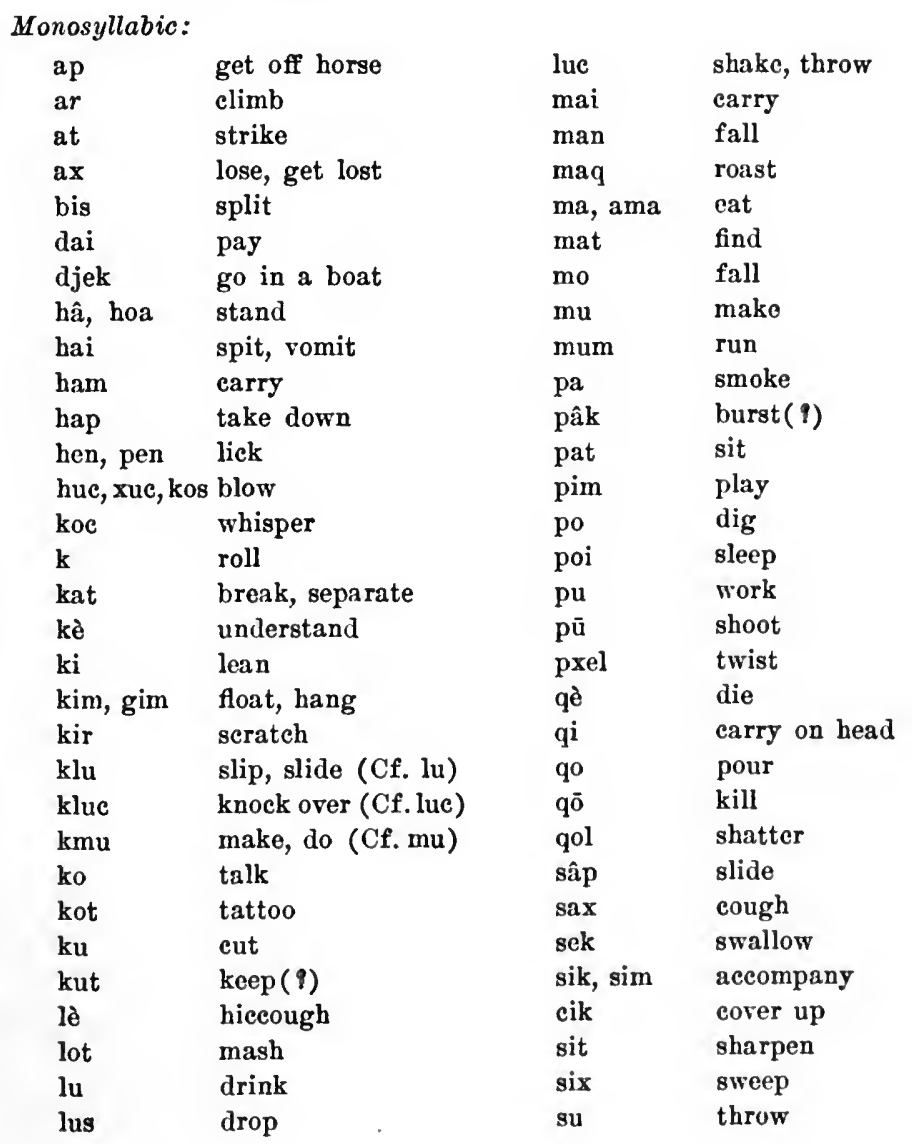




$\begin{array}{ll}\text { sum } & \text { look for } \\ \text { ta } & \text { pull, tear } \\ \text { tak } & \text { sing } \\ \text { tös } & \text { break } \\ \text { tot } & \text { bury } \\ \text { tu } & \text { fly } \\ \text { txax } & \text { abandon } \\ \text { tra } & \text { spread out, tear } \\ \text { tcex } & \text { break in two } \\ \text { tci, tcit } & \text { squeeze( }(9) \\ \text { teu } & \text { sleep }\end{array}$

$\begin{array}{ll}\text { tcum } & \text { marry } \\ \text { texua } & \text { fight } \\ \text { wa } & \text { go, travel } \\ \text { whek } & \text { push } \\ \text { wō } & \text { cry } \\ \text { wo } & \text { sit } \\ \text { xai } & \text { make } \\ \text { xadj, xate } & \text { steal } \\ \text { xū } & \text { swim } \\ \text { xu } & \text { whistle }\end{array}$

Polysyllabic:

$\begin{array}{ll}\begin{array}{l}\text { adap } \\ \text { amē }\end{array} & \begin{array}{l}\text { grow } \\ \text { hungry (Cf. am, } \\ \text { ama, eat) }\end{array} \\ \text { mi 'ina, i 'ini like, love } \\ \text { inada } & \text { wait for } \\ \text { koru } & \text { bend } \\ \text { licxu } & \text { lose } \\ \text { luli, luri } & \text { drop, fall } \\ \text { mamat } & \text { alive } \\ \text { nook } & \text { recover } \\ \text { oru } & \text { reach up for }\end{array}$

$\begin{array}{ll}\text { samut } & \text { stay behind } \\ \text { samxu } & \text { dance } \\ \text { trahu } & \text { know } \\ \text { teiwa } & \text { sell } \\ \text { wemtso } & \text { gamble } \\ \text { xaca } & \text { yawn } \\ \text { xatutu } & \text { snore } \\ \text { xaxo } & \text { pull } \\ \text { xiaxe } & \text { rub } \\ \text { xota } & \text { watch }\end{array}$

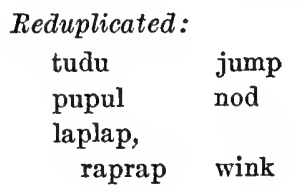

$\begin{array}{ll}\text { lolo } & \text { cut up } \\ \text { potpot } & \text { boil } \\ \text { xexe } & \text { sweep }\end{array}$

\section{ADJECTIVES.}

Adjectival stems are commonly polysyllabic. The attributive and predicative forms are alike, and the former precedes the noun, whereas the latter follows. In their combination with the pronominal elements, some take these before, some after the stem," as pointed out previously, but no rule has been found for the varied use.

\section{NUMERALS.}

The numeral system of the Chimariko is quinary up to ten and then continues decimally. Six is 1-cibum, seven is 2-sbum, eight is 4-cibum, nine is 1-tcigu, ten is sa'an-1, eleven is 1-lasut or 1-rasut, twelve is 2-risut or 2-lsut, thirteen is 3-risut or 3-ulsut, and so on regularly to twenty, which is two-ten, xoku-mtun 
sa'anpun. Thirty is three-ten, xoda-m-tun sa'anpun, and one hundred is wood-one, pucua-pun. Numerals seem to be unchanged, and do not vary with things eounted.

\section{POSTPOSITIONS.}

The paueity of locative suffixes in the noun is in part made up for by a few postpositions, which serve to point out locative ideas. But two have been tentatively identified, and their use may be seen from the following:

āwa xunoi yeaxu'nmoxanan pusua hiya'talot teūmū house into I shall go

board it lies under

\section{CONNECTIVES.}

Chimariko is apparently rather destitute of conneetives. In the text fragments secured, they do not appear at all, but the texts are elearly somewhat disjointed, and so do not serve as satisfactory material to judge from. The complete absenee of connectives, however, seems to point to their eomparative rarity.

\section{ORDER OF WORDS.}

The usual order of words is subject-verb-object, or subjectobject-verb. In some eases, however, partieularly when the subject is pronominal, the order is reversed, object preceding subject. In the transitive verb when the independent pronoun is used as object, the order is regularly subject-verb-objeet. When one of two nouns stands in a possessive relation to the other, the possessor always preeedes the thing possessed.

\section{CONCLUSION AND RELATIONS.}

Compared with neighboring linguistic families, Chimariko oceupies a somewhat intermediate position. In phonetie character it lies rather between the smooth, vocalie languages of the Central Californian type, and the harsher, more consonantal Northwestern type. In this respect it is like the Shastan family, and may be regarded on the whole as belonging to that group. In its use of incomplete ineorporation and its lack of plural it also 
resembles this type, but differs from it in its lack of syntactical cases, and its greater paucity of nominal locative suffixes. In common with the Shastan languages, and some of those of Central California, is its use of verbal instrumental prefixes. It will be seen, therefore, that Chimariko does not fall distinctly into either the Central or Northwestern morphological group, and may more properly be regarded as belonging to the Shastan type. In the general classification of Californian languages recently proposed, ${ }^{13}$ Chimariko was placed with the Northwestern type, but it was stated that it showed less clearly than the others of that group the distinctive features upon which the group was based.

The considerable degree of similarity in grammatical and phonetic character between the Chimariko and the Shastan family, lends further interest and importance to certain curious features on the lexical side. Comparison of Chimariko with Hupa and Wintun shows practically nothing in the way of lexical resemblance, and in the case of Wintun at least, less than one might expect in the way of direct borrowing between two adjacent and friendly tribes. If comparison be made however with the Shastan family, a different situation is revealed, for between forty and fifty cases have been noted here, in which lexical correspondence is clear or probable. The similarities are found in words of varied classes, including parts of the body, animals, artificial and natural objects, and verbal stems. Further, a number of verbal instrumental prefixes and directive suffixes, and perhaps pronominal elements, show agreement also. So considerable a number of lexical similarities, and with so wide a range, brings up sharply the question how far such agreements ${ }^{2}$ are to be regarded as due to borrowing. That one language should adopt from another a few words is to be expected; but can the possession of common forms for such fundamental words as head, ear, mouth, tooth, tongue, man, woman, fire, water, deer, rattlesnake, and several numerals, and such verbal stems as to eat and to see, be explained on this basis? The explanation of borrowing here is made more difficult in view of the further fact

13 Dixon and Kroeber, The Native Languages of California, Am. Anthr., n. s., V, $18,1903$. 
that the larger number of similarities are not between Chimariko and its immediate neighbor the Shasta, but between Chimariko and the Atsugewi and Achomawi, members of the Shastan family, but separated from the Climariko by the whole extent of Wintun and Yanan territory. As has been pointed out, ${ }^{14}$ the Achomawi and Atsugewi are lexically widely divergent from the Shasta, and in many cases Chimariko agrees with forms in Achomawi or Atsugewi where their stems differ wholly from Shasta. If borrowing is the explanation of these agreements, then we must assume that the Chimariko and Achomawi and Atsugewi were formerly contiguous peoples, since separated by migration. Such movements must have been however relatively old, as no traditions or other evidenees of migration are observed. If, on the other hand, the similarities are regarded as of such character and number as to point to real genetic relationship, then we have another instance of the great degree of differentiation which has taken place within the Shastan family. That this is unquestionably great, is shown by both Achomawi and Atsugewi, and the problematical Konomihu, with which latter indeed, there are one or two agreements in Chimariko. The fact that, in spite of the close association of the Chimariko with the Wintun, there has been practically no borrowing, and that the phonetics and grammar of the Chimariko show close similarities with those of the Shastan family, makes the probability of real relationship much greater.

The following list illustrates the more striking instances of lexical agreement between the Chimariko and Shastan families:

\begin{tabular}{|c|c|c|c|c|}
\hline & Chimariko. & Shasta. & Achomawi. & Atsugewi. \\
\hline $\begin{array}{l}\text { arm } \\
\text { armpit }\end{array}$ & $\begin{array}{l}\text {-tanpu } \\
\text { cilēitcumuni }\end{array}$ & & $\begin{array}{l}\text { lapau } \\
\text { amdjilex }\end{array}$ & tumiteilèha \\
\hline blood & cötri & & & icurīi \\
\hline ear & -sam & isak & isat & \\
\hline eye & - sot & & a'sa & \\
\hline excrement & -waxni & & & wehki \\
\hline head & $-m a$ & -na(Konomihu) & $\operatorname{lax}$ & naxa \\
\hline intestines & $-p \times a$ & ipxai & bitsxol & bitsxaru \\
\hline $\operatorname{leg}$ & txan & xatis & & \\
\hline liver & $-c i$ & äpci & & \\
\hline
\end{tabular}

14 Dixon, The Shasta-Achomawi: A New Isinguistic Stock, with Four New Dialects, Am. Anthr., n. s., VII, 213-217. 


\begin{tabular}{|c|c|c|c|c|}
\hline milk & $\begin{array}{l}\text { Chimariko. } \\
\text { cïira }\end{array}$ & $\begin{array}{l}\text { Shasta. } \\
\text { itsik }\end{array}$ & $\begin{array}{l}\text { Achomawi. } \\
\text { etcit }\end{array}$ & $\begin{array}{l}\text { Atsugewi. } \\
\text { atciska }\end{array}$ \\
\hline mouth & (ha) wa & $\mathrm{au}$ & ap'bo & ap'bo \\
\hline neck & $-k i$ & & & op'ki \\
\hline teeth & -tsu & etsau & itsa & itsau \\
\hline tongue & -pen, -hen & ehena & & \\
\hline $\operatorname{man}$ & itri, itci & ic & & \\
\hline woman & puntsar & daritei & & minridsara \\
\hline ant & pelo'a & & blamasa & \\
\hline deer & a'a & adau, arau & & \\
\hline raccoon & yeto'a & & & toh'kaa \\
\hline rattlesnake & qawu & xowatid & häuta & \\
\hline wolf & citciwi & tciwa & $\mathrm{t} \operatorname{sim} u$ & \\
\hline acorn & yutri & & & yummi \\
\hline willow & pate'xu & & bas & patcu \\
\hline day & ase & atcaii & & assīyi \\
\hline fog & aptum & & datumumdji & \\
\hline fire & $a^{\prime} p u$ & & & pah'yi \\
\hline smoke & $\mathrm{qe}$ & & maqets & \\
\hline stone & qa & $\begin{array}{l}\text { kwasunip } \\
\text { (Konomihu) }\end{array}$ & & \\
\hline $\operatorname{sun}$ & alla & & tsul & \\
\hline water & aka & atsa & as & ats'si \\
\hline winter & asoti & & astsui & \\
\hline arrow & sã & & $\begin{array}{l}\text { sat (arrow- } \\
\text { point) }\end{array}$ & \\
\hline bow & xâpuneu & xau & & \\
\hline deer-trap & haxaktca & & & hatsda \\
\hline fishline, hook & hamamegutea & amai & damame & \\
\hline spear & hasunwedeu & & lasu & nasu \\
\hline soup-basket & poqela & yapuk & & \\
\hline two & xok'u & xokwa & hak & hoki \\
\hline three & xodai & xatski & tsasdi & kiski \\
\hline five & tsanehe & ètsa & & tsanse \\
\hline to eat & -am-, -ama- & & -am- & -ammi- \\
\hline to carry & -mai- & & -nuu- & \\
\hline to ery & -wo- & & -wo- & \\
\hline to dent & -kxol- & & -qol- & \\
\hline to drop & -lus-, -lur- & & -lup- & \\
\hline to pull off & -pul- & & -pil- & \\
\hline to see & -mam- & & -nima- & -ima- \\
\hline with the foot & mitci- & & tsi- & \\
\hline with the hand & tu- & & & to- \\
\hline by sitting on & wa- & & & we- \\
\hline downwards & $-\mathrm{mi}$ & & $-\mathrm{mi}-$ & $-\mathrm{mi}$ \\
\hline across, through & $-\mathrm{smu}$ & & & -snu (into) \\
\hline out of & $-\operatorname{tap}$ & & & $-\mathrm{ta}$ \\
\hline $\mathrm{I}$ & tc & & s & $\mathbf{s}$ \\
\hline thou & m & & & $\mathrm{m}$ \\
\hline this & qe & & & qepi \\
\hline
\end{tabular}


In the present state of our knowledge of the extent to which borrowing has taken place in California at large, it is difficult to arrive at a definite solution of the question of the relationship of Chimariko with the Shastan family. The extent of the similarity in this case, however, points to the necessity of a thorough investigation of the whole matter of borrowing throughout the state. The question also involves the mueh wider one of the real limits of genetic relationship, in the need of determining the character and number of agreements which shall be regarded as essential to establish common deseent.

\section{TEXTS.}

The following text fragments comprise all that was secured. The translation is often doubtful, but as a rule, that which was given by my informant has been given, with queries where the meaning is evidently wrong. The same word is often spelled differently in different places, it seeming better to give the forms just as they were heard at the time, rather than to attempt to reduce them to a common spelling. Not infrequently the text forms differ from those secured in the paradigms of grammatical material. Explanations and diseussion of uneertain points are given in the notcs. I have attempted to give a running translation of three of the tales, but they are so fragmentary and confused, that it is almost impossible.

\section{THE SORCERER.}

himi'santo haa'tpikta ${ }^{1}$ tcima'r oha'tida ${ }^{2}$ hako't ${ }^{3}$

(Sorcerer) he comes out a person shooting magically he kills

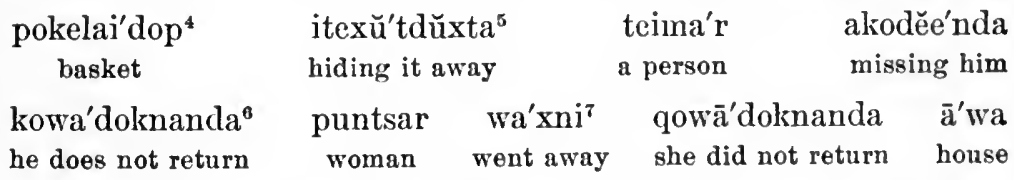
natciwa'mda ${ }^{8}$ qowa'doknanda hō'wadokta ${ }^{9}$ qè'wokinda ${ }^{10}$ she went to she did not return she did not return (?) said she was sick

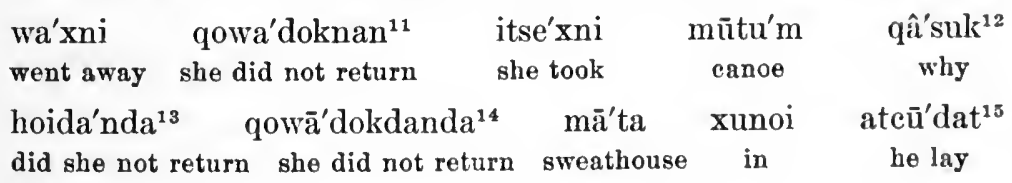




\begin{tabular}{|c|c|c|c|c|}
\hline $\begin{array}{l}\text { itcūkar }{ }^{10} \\
\text { drowned }\end{array}$ & $\begin{array}{l}\text { wa'mdaanda }{ }^{17} \\
\text { he went off }\end{array}$ & $\begin{array}{l}\overline{\text { uppo }}{ }^{\prime 18} \\
\text { track }\end{array}$ & $\begin{array}{c}\text { wuqā'danda }{ }^{1 s} \\
\text { (q) }\end{array}$ & $\begin{array}{l}\text { owa'xtanda } \\
\text { he went off }\end{array}$ \\
\hline $\begin{array}{l}\text { howa'mtanda } \\
\text { he has gone }\end{array}$ & $\begin{array}{l}\text { hiwo'nd } \\
\text { he stays }\end{array}$ & \multicolumn{2}{|c|}{$\begin{array}{l}\text { ima'mni }^{21} \\
\text { I see him }\end{array}$} & $\begin{array}{l}x \bar{u} x w \bar{o}^{\prime} \text { danapton } \\
\text { didn't look at him }\end{array}$ \\
\hline $\begin{array}{l}\text { hiwō'mda } \\
\text { staying }\end{array}$ & $\begin{array}{l}\text { atcū'danda } \\
\text { he lies down }\end{array}$ & $\begin{array}{l}\text { pun } \\
\text { one }\end{array}$ & $\begin{array}{l}\text { puntsa'ri } \\
\text { woman }\end{array}$ & madě'patinda \\
\hline $\begin{array}{l}\text { hama'mdands } \\
\text { he eats }\end{array}$ & $\begin{array}{l}\text { huwū'r } \\
\text { I am }\end{array}$ & $\operatorname{lan}^{22}$ & $\begin{array}{l}\text { dime'da } \\
\text { tomorrow }\end{array}$ & $\begin{array}{l}\text { xūno'mnitcku } \\
\text { Salmon River to }\end{array}$ \\
\hline$\underset{\text { place }}{\operatorname{amai} \mathrm{da}}$ & $\begin{array}{l}\text { nūu'mxanan. } \\
\text { I am going. }\end{array}$ & & & \\
\hline
\end{tabular}

\section{NOTES.}

1 ha-a-tpik-ta. The suffix -tpi, out of, seems sometimes to occur with a final k. The suffix -ta may be the participle. The stem is a.

2 The stem -hat- also occurs in the following: nihatxa, poke; nohat'öi, close window. -ida is the participial suffix.

3 Probably contracted from ha-ko-tinda.

* Contracted from pokelaida-op. The suffix is the intensive.

5 This stem occurs also as -txat-. The suffix occurs also in himai'dukta, he carried it home. See note 6.

6 Ko is xo, negative prefix. -wa-dok, to return, from -wa-, -owa-, to go, and -dok a suffix apparently meaning backwards, or toward speaker.

7 Perhaps contracted from ōwa'xni.

8 Perhaps nātci-awamda, we go. The first person plural has not been found elsewhere without the intensive suffix -dut.

o Probably participial.

10 This stem also occurs as qēdjok-, qētcok-.

11 Shortened from qowa'doknanda.

12 Interrogative of uncertain meaning.

13 Verbal stem here is obscure. Negative prefix ho- is xo-.

14 No explanation of the difference between -danda and -nanda could be secured.

15 The stem -teu- is also used for to sleep. The ending -t occurring quite frequently in the texts, after participial and other endings, is found but rarely in the paradigms secured. Its function has not been made out.

16 The stem here is -tcuk-.

17 Abbreviated (q) from howam'danda.

18 Literally his-foot.

19 The stem appears to be qā-, which occurs also in nuqā'duha, lie on back, nuqā'ohunmi, lie on belly.

20 For hiwo'mda. The stem apparently also oceurs as -wam-, as in iwa'mdaxanan, I'll stay. Owa-, -owam- on the other hand means to go.

21 Analyzed as i-mam-ni, $i$ being the pronominal prefix of the first person singular, and -ni the suffix of the present tense.

22 Probably for howa'mxanan. The stem is owam, howam, with the future suffix - xan.

23 See previous note. 
II. THE FLOOD.

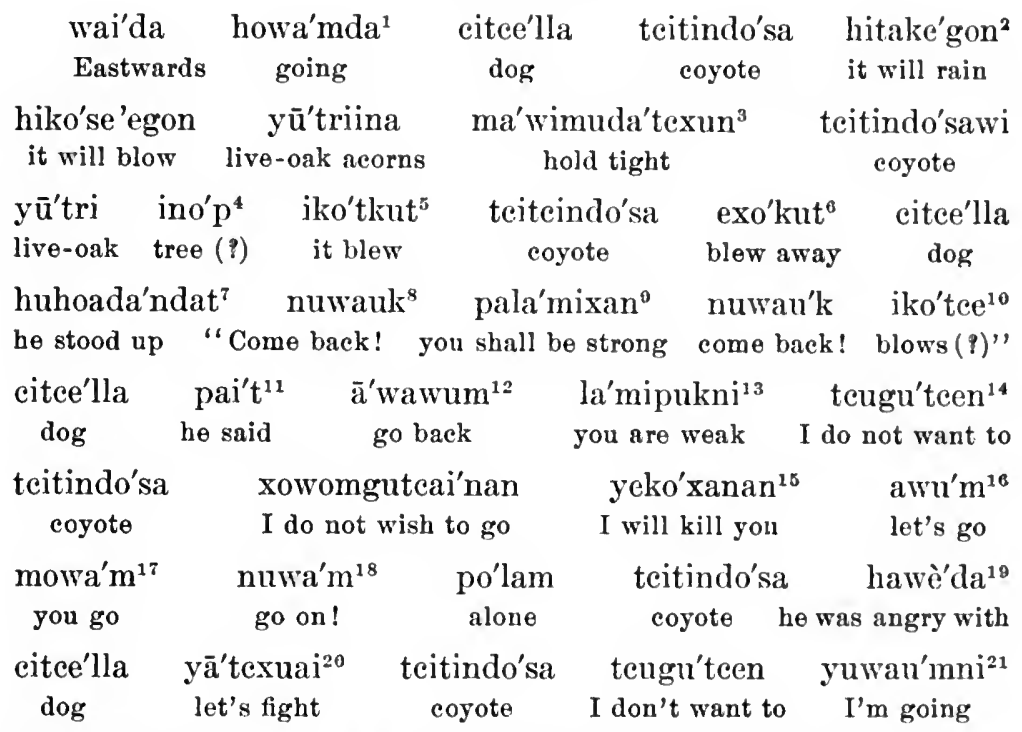

amā'misudaye ${ }^{22}$

ā'mamiknati'nda ${ }^{23}$

that is not your place

yowa'mdaxanan ${ }^{24}$ I shall go

is that your place

yūwa'ktaktcai'nan ${ }^{25}$

citce'lla xomi"inanan ${ }^{20}$

I do not want to go around dog

mice'qe ${ }^{28}$

"miceqe"
I don't like

$\underset{\text { nephew }}{\operatorname{mica} \mathrm{kui}^{2 \theta}}$

awakdaxa'n ${ }^{27}$ let's go around husi'kdaktcai'nan ${ }^{31}$ yetcu'mdaxanan ${ }^{32}$ mice'qe teitindo'sa he doesn't want to follow I'm going to get married "miceqe" coyote

$\begin{array}{ccc}\text { howa'ktayanaxa'nan }^{33} & \text { yetcu'mdan } & \bar{a}^{\prime} q i t c u ' k d a m h u t^{34} \\ \text { I am not coming back } & \text { I am married } & \text { water flood }\end{array}$

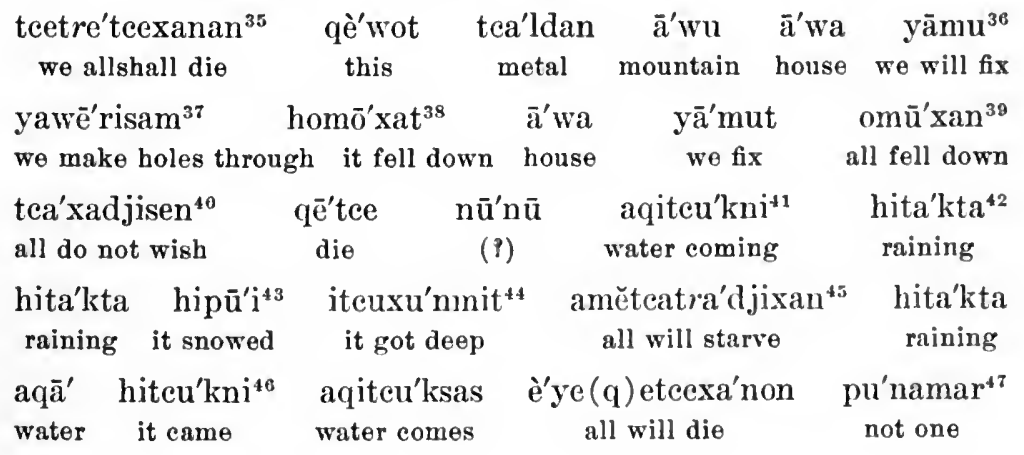




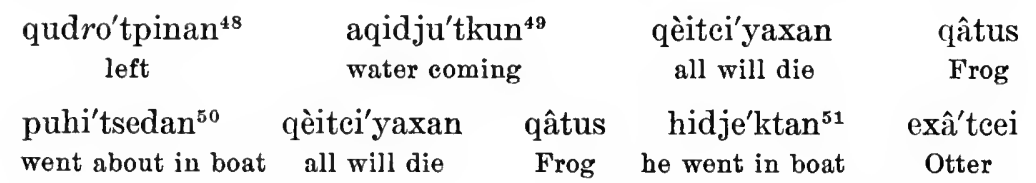

$\begin{array}{lccccc}\text { aqi'ktan }^{52} & \text { hūnéri } & \text { aqi'ktan } & \text { tci'mar } & \text { tcetra'xut }^{53} & \text { pun } \\ \text { he floated } & \text { Mink } & \text { he floated } & \text { people } & \text { all dead } & \text { one }\end{array}$

$\begin{array}{ccccc}\text { me'matinda }_{\text {alive }} & \text { tei'mar } & \text { hupo'n }^{55} & \text { tea'txun } & \text { himat'ta } \\ \text { person } & \text { his rib } & \text { bone } & \text { he found }\end{array}$

\begin{tabular}{|c|c|c|c|c|}
\hline $\begin{array}{l}\text { xa'ndakut } \\
\text { I keep it }\end{array}$ & $\begin{array}{l}\text { ixotawè't }{ }^{58} \\
\text { I look at it }\end{array}$ & $\begin{array}{l}\text { tea'ts } \\
\text { bon }\end{array}$ & & \\
\hline $\begin{array}{l}\text { xara'lima't }{ }^{\prime} t^{60} \\
\text { baby find }\end{array}$ & $\begin{array}{r}\text { aumgilo } \\
\text { in baske }\end{array}$ & $\begin{array}{c}\text { xaro'la } \\
\text { baby }\end{array}$ & & \\
\hline $\begin{array}{l}\text { itxa'n } \\
\text { I kee }\end{array}$ & $\begin{array}{l}\text { hamé' } \mathbf{u}^{63} \\
\text { food }\end{array}$ & e ate & $\begin{array}{l}\text { ha'ral } \\
\text { baby- }\end{array}$ & \\
\hline
\end{tabular}

puntsa'la $^{65}$ olè'da hiwo't ${ }^{66}$ puntsa'lla pun i'tri pā'tcigut ${ }^{67}$ girl small sat girl one man none

\begin{tabular}{|c|c|c|c|}
\hline $\begin{array}{l}\text { tci'mar } \\
\text { persons }\end{array}$ & $\begin{array}{l}\text { xoku }^{\prime} \mathrm{lit}^{68} \\
\text { we are two }\end{array}$ & $\begin{array}{l}\text { ěpatma'mdat }{ }^{69} \\
\text { we remain }\end{array}$ & $\begin{array}{l}\overline{\mathrm{I}}^{\prime} \text { trirop } \\
\text { that man }\end{array}$ \\
\hline
\end{tabular}

$\begin{array}{cccccc}\overline{\mathbf{a}} \text { ”a } & \text { puntsa'la } & \text { amanu } \bar{u}^{\prime} \text { da } & \bar{i}^{\prime} \text { tri } & \text { awa'nhut } & \text { owelai'72 } \\ \text { deer } & \text { girl } & \text { he fed } & \text { man } & \text { I stay } & \text { little boy }\end{array}$

$\begin{array}{crccc}\text { dah'ta } & \text { etaxa'nat } & \text { tei'mar } & \text { owelai'top }^{74} & \text { itrí'hida }^{75} \\ \text { born } & \text { many shall be } & \text { people } & \text { boy } & \text { growing }\end{array}$

$\begin{array}{ccccc}\text { mahinoi'yat } & \text { puntsa'la } & \text { tcimar } & \text { etaxa'n } & \text { āqitcu'ktam } \\ \text { had children } & \text { girls } & \text { people } & \text { will be many } & \text { water-flood }\end{array}$

hinoo'kni tco'tan hamē'u i'trihinda qấtci hiā'daptcehanda ${ }^{76}$

food is growing grass growing now

yū'tri ameba'nda mu'ně ameba'nda hēputciina acorns are plenty black-oak areplenty live-oak acorns amĕbanda ya'qa aměba'nda hĕcigo hatciani'nda are plenty white-oak acorns are plenty hazel are many tci'miana amĕba'nda tcī'tci aměba'nda $\bar{u}^{\prime}$ muli hiě́tjumunda sarvice-berry are plenty manzanita is plenty salmon come many

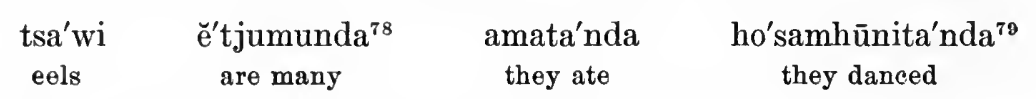
hē'uma'htanda ${ }^{80}$ hü'ktatandaman owa'ktihēinda ${ }^{81}$ tci'mar gambled many go about they $\operatorname{com} \theta$ people

pohimta'nda hosa'm hūnidē'u pohimta'nda ${ }^{82}$ tci'mar

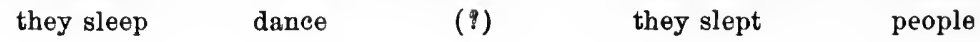




$\begin{array}{cc}\text { wa'ktixēinda }^{83} & \text { hepata'nda }^{84} \\ \text { went about } & \text { they stayed } \\ \text { hitxa'itanda }^{86} & \text { xema'non } \\ \text { they finished } & \text { I am not eating }\end{array}$

pomū'yen
I'm sleepy
I'm not going

$\begin{array}{cc}\text { ha'matanda } & \text { ha'madēu } \\ \text { they ate } & \text { food }\end{array}$

yuma'mxanan xema'non

I'm going off I am not eating qèdjo'kni ${ }^{88}$ hũtimhuktcai'nan I am sick follow I don't want to

$\begin{array}{cccc}\text { nūwa'man } & \bar{a}^{\prime} w a m & \text { himollai' }^{\prime} & \text { mowa'mimi 'ina } \\ \text { you go } & \text { let's go } & \text { niece } & \text { you want to go. }\end{array}$

NOTES.

1 Probably participial.

2 The more common future suffix -xan is sometimes -gon, as here, and elsewhere.

3 The verbal stem here is -imu-, to hold. The form is second person, future, the forec of the suffix -ate being here obseure.

4 The more usual word for tree seems to be at'a, atsa.

s The usual stem for "to blow" is -kos-, koc-, -xos-. This form -kotappears again below, and also in hekoteu, tattoo-mark. The suffix -ku implies separation.

"Another form of the stem for "to blow," seen also in teoxü'xanan, I shall blow away, and in yoxun'ot, I whistle.

7 The stem is -hoa-, -hâ-; seen also in yohōadaxanan, I shall stand up, nuhâ'da, stand up!

8 With the impcrative prefix $\mathrm{n}$ - . -wauk is probably a contraction from -watok-. Other forms are -wok-, -wak-, -wax-.

9 Pala-is the stem, -xan the future suffix, -mi the suffix of the second person singular.

10 The suffix tee appears also in such forms as moxolitee, you are bad, maxawintcei, you are old.

11 The stem here is pa-.

12 Probably the same stem as -owa-. Occurs also in natcidut $\bar{a}^{\prime}$ wam, we go, ya "aye, I go for, awu'm, let's go.

13 One of the apparent cases of infixed pronouns, la-mi-puk-ni. Laalso occurs as la-i-dam-ni, I am tired, la-mi-dam-a, are you tired?

14 Apparently from a stem -tcai-, tee-, to wish, desire. Seen also in such forms as xowā'mguteainan, I won't go.

15 The stem is -ko-. Ye- is the pronominal prefix of the first person singular, -xanan the future suffix.

10 See note 12.

17 Stem is -owa-. M- is the pronominal prefix of the second person singular.

18 Imperative.

19 The stem here is apparently - $w \bar{e}-$, seen also in teaw $\bar{e}^{\prime}$ pan, I am angry with you, mawe'ni, you are mean, surly.

20 This stem -texua' - is seen also in yetexua'xanan, I shall fight; mētexua', have you been, are you fighting?

$21 \mathrm{Y}$ - is the pronominal prefix of the first person singular; the stem is -owa- and the suffix $-\mathrm{ni}$ is that of the present tense.

22 Ama-mi-su-da-ye. Perhaps "place-your-being"'; see under Pronoun, possessive. 
23 The $\cdot \mathrm{k}$ - here is the negative.

24 The use of the prefix -da with the suffix of the future is frequent.

25 Probably contracted from y-uwa-tok-da-k-tcai-nan, the - $k$ - being the negative. For -tcai- see note 14 ; -tok-, -ok is a suffix meaning backwards.

26 The negative preflx xo-, with the stem -mi'inan-

27 See note 12. The $-\mathrm{k}$ - is here again negative.

28 An exclamation characteristic of Coyote, and frequently used by him.

20 Not the usual form, which is himollai.

30 Either maternal or paternal apparently.

31 The stem is -sik-, seen also in yusi'mxan, I'll follow; mexasi'-mnatexun, don't you follow. The prefix is that of the third person singular.

32 The stem is -teum-.

33 The prefix $h$ - is apparently the negative, which is more usually $x$-.

34 Obscure. The same stem appears in niteu'ktam, to lie on ground, of a round thing; also perhaps in hiteu'kni, he drowns.

35 Probably modified from teet-qe' ${ }^{\prime}$-tce-xanan. The use of tee- both before and after the stem -qe-, to die, seems intended to intensify the meaning, we all.

36 The stem here is -mu-, appearing also in $\overline{1}^{\prime}$ muxanan, I will fix. The prefix is that of the first person plural. a hole.

37 The stem is -wer-, -wel-, seen also in hawe'lsamni, it goes through

38 Translation doubtful. Probably homu'xat, from the same stem as ya'mu.

30 See note 38.

40 Translation doubtful. Apparently tea-xa-djisen, the stem -dji- being perhaps related to -teai-, to wish, desire.

41 See note 34.

42 Probably participial. The stem -tak- seems to be homophonous with that for to sing.

43 The stem is apparently -pūi-, not to be confounded with -pu-imu- as in i-püi-mukni, I pinch (with-fingers-press, hold-tightly).

44 Probably hi-teu-xun-mi-t. The prefix teu-indicates a bulky object. The stem -xun- appears also in nitcuxu'nmi, pound down a nail; notsoxu'nmu, bore a hole; ni'axunmutpu, put cap on pen, cover on box. The suffix -mi seems to refer generally to the ground, or motion downwards, as nya'tmi, a flat thing lies on ground; nuqa"ohunmi, lie on belly.

45 See note 35. The two forms seem to be identical, except for the addition here of ame-, meaning hunger.

46 See note 34 .

47 Pun is the numeral "one."

48 Translation doubtful. The suffix -rotpin occurs in the forms pu'nusrotpin, one left; $x^{\prime}$ 'kosrotpin, two left.

49 Probably aqi-teut-xan, for aqi-teuk-xan. See note 34 .

50 The stem seems to be -tse-, seen also in itse'xni, she took boat.

51 The stem here, -djek-, tcek-, seems to be related to that in itse'xni.

52 Probably participial. Two explanations of this form seem possible, either aqi-k-tan, water-rolling (-k-, to roll, move over surface), or (h)aqik-tan, the stem -qik-being for -qim-, -kim-, seen in aki'mni, he floats.

53 See note 35 .

54 Compare ma-i-mat-ni, I am alive; ma-mi-mat-a, are you alive?

$55 \mathrm{Po}$ is elsewhere always used for foot. 
56 Stem is -mat- seen also in ima'tni, I find. Probably partieipial.

s7 Other comparable forms are, miti'nda kutaxa'na, shall you keep it; icehe'nda kutaxa'na, I shall keep it. Itxan is the word for leg.

58 The stem is apparently -xota-, seen also in: ixo'taxanan, I shall wateh; yaxotai'yaxan, we shall look for. The xo-does not seem to be the negative. The suffix - wet is a continuative. Compare imu'mwet, I run cointinually; yema'wet, I eat constantly.

59 If -wo- is the stem, this means to sit, as in $i^{\prime}$ wo, I sit; hi'wotinda, he sits. For -xun- see note 44 . The ending is puzzling.

60 Apparently a ease of nominal incorporation, xarala-himat'ta, babyhe-finding. Another form for the noun was given as xalŭ'la.

61 Small is ulë'da. This is apparently run together in rapid speech with hima't'ta.

62 See note 57.

63 Noun formed from the stem -am-, -ama-, to eat.

64 The usual form would be ha'ma. The pronominal prefix of the third person is however quite frequently omitted. The final -t here and in other eases does not oeeur in the paradigms of verbal forms secured.

65 From puntsar, woman. The suffix -la oeeurs in many names of animals and of relations, the form here being probably puntsalla, the interchange or equality of $\mathrm{r}$ and $\mathrm{l}$ being clearly marked in many words.

66 See note 59.

67 Derived from the demonstrative stem pa-. Other derivatives are seen in pāteea'mku, something; pātci, what; $p \bar{a}^{\prime}$ teigun, no. The suffix .gun, -gut is the negative.

08 Probably for xoku'litea. Cf. tcima'rtea, we are men, Chimarikos.

69 The stem -pa- oceurs also in ya'patcen, we stay with.

io The intensive suffix -op, -ot. Refers to the partieular man previously spoken of.

71 The stem is apparently -pū-, to shoot. The xa-may be the negative, in the sense of not shooting, i.e., stalking, hunting, I stalk game being given as yexapō'unu. The same prefix (?) oeeurs apparently also in nexadu'mxu, cook, boil it!

72 The usual word for boy is itri'la. This same stem appears again in ōwe'lüla, bachelor.

73 From eta, many, with future suffix and final -t.

74 See note 70 .

75 Literally "'man-becoming."

76 The only comparable form is na'tap, sift!

77 Elsewhere the stem ame- means hungry.

78 Perhaps connected with eta, many.

79 The stem is -samxu-. Cf. isa'mxuni, I dance; misa'mxuni, you dance.

80 The more eommon stem is -wentso: hiwe'mtson, he gambles.

81 In the paradigms secured, this is given as owa'kni, or owa'ktinda.

82 The stem is -po- or -poi-. Cf. poi'mni, I sleep; pomu'yen, I am sleeping; poa'nmu, are you sleeping?

83 See note 81.

84 See note 69 .

85 See note 63 .

80 The stem is apparently -txa-. Cf. itxa'Eni, I stop, cease.

87 Negative. Cf. ma'mut maxa'mana, you are not eating; nā'teidut ya'xamanat, we are not eating.

88 Derived from the stem qē-, to die.

89 Compound form, from -wa-, -owa-, to go, and -mi'ina-, to wish. 


\section{FREE TRANSLATION.}

Dog and Coyote were travelling eastwards. Dog said, "It is going to rain, it is going to blow. Hold tight to a live-oak tree." It blew, and Coyote was blown away. Dog stood there and called, "Come back, you shall be strong." Coyote did not wish to, for he was angry with dog. The latter said, "Let us fight," but Coyote declined. After some discussion they agreed to travel about, and get married. A flood was coming on, in which they believed they would be drowned, so they tried to make a metal( $(\xi)$ house, but it fell down. Water came, it rained and snowed, and all people were starved and lost. Frog was floating in a canoe, and Otter and Mink floated on the water. Frog found the rib of one of those who had been drowned. At sunset it became a baby, which was put in a basket. The girl baby grew up, and married Frog(q), and to them a child, a boy was born, and by and by there were many people. There was an abundance of food then, and people went about eating and dancing, and living as they do now.

\section{THE UNSUCCESSFUL HUNTER.}

$\begin{array}{cccc}\text { ĕxapū'umut }^{1} & \text { hako'nwadukta }^{2} & \text { hï'tcip } & \text { himai'dukta } \\ \text { He hunted } & \text { he didn't kill } & \text { his thigh } & \text { he carried back }\end{array}$

hutrinē'u imai'dukta tca'koasun ${ }^{5} \quad \bar{a}$ 'a kogutxu'kni ${ }^{6}$
intestines he brought back I'm good hunter deer you don't like me i'trirok $^{7}$ aqa' ya'aye $^{8}$ pu'ntsarop yatcaxi'sxun ${ }^{9}$ wisèda that man water I go for that woman they ran off down river awa'tmun axă'wayaguktcainan ${ }^{11} \quad$ éwō'mut $^{12} \quad \mathrm{i}^{\prime}$ trirop went did not want to come back he cried that man

\begin{tabular}{|c|c|c|c|c|c|}
\hline \multicolumn{2}{|c|}{$\begin{array}{l}\text { kuto'kkutcai'dananda }{ }^{13} \\
\text { never coming back }\end{array}$} & tcūm ${ }_{(q)}^{14}$ & tcūm & $\begin{array}{l}\text { tcisi't } \\
\text { I said }\end{array}$ & $\begin{array}{l}\text { hatcisé'nda }{ }^{15} \\
\text { not following }\end{array}$ \\
\hline $\begin{array}{l}\text { ĕwo'maminda }{ }^{16} \\
\text { still crying }\end{array}$ & $\begin{array}{l}\text { i'trirop } \\
\text { that man }\end{array}$ & $\begin{array}{l}\overline{1}^{\prime} \text { trirop } \\
\text { that man }\end{array}$ & & $\begin{array}{l}\text { o'munda } \\
\text { erying }\end{array}$ & $\begin{array}{l}\text { pu'ntsarop } \\
\text { that woman }\end{array}$ \\
\hline $\begin{array}{l}\text { xomi"inanan } \\
\text { I don't like }\end{array}$ & $\begin{array}{l}\text { xowa'mgu } \\
\text { I do not }\end{array}$ & $\begin{array}{l}\text { tcai'danan } \\
\text { wish to go }\end{array}$ & $\begin{array}{r}\text { uwi } \\
\text { (?) }\end{array}$ & $\begin{array}{l}\text { ya'pa } \\
\text { we }\end{array}$ & $\underset{(q)}{u w i^{\prime} \mathbf{r}}$ \\
\hline
\end{tabular}

ya'pa'en xowa'mgutcainan yowa'manda xo'wadumgutcai'nan we stay with don't want to go I going don't want to go home again awa'mai yä'pat hisi'k tcutcxèmun ělo'hni

(?) (?) good (?)

xowa'mgutcai'nan tcugu'tcen xomai'muktcainan ${ }^{18}$ hīmidanda $^{19}$ I don't want to go I don't want to I don't want to earry it is heavy texalè'gu $^{20}$ imai'momen $^{21}$ xuxodaktcai'nan ${ }^{22}$ xugonaktcai'nan ${ }^{23}$ light-not I earry I don't want to watch I won't talk to you 
tcudi"ineman

(?) teupi'tan ${ }^{24}$

my foot is sore xowa'mgutcainan

I don't want to go

moxoligě'ěūni ${ }^{25}$ tcū'itexēmun ${ }^{28}$ xowa'mgutcainan teumai'idan you are no good I drag away (?) I don't want to go I carrying

\begin{tabular}{|c|c|c|c|c|}
\hline $\begin{array}{l}\text { uwa'xyen } \\
\text { (?) }\end{array}$ & $\begin{array}{cr}\text { exxé'u }^{-} & \text {itex } \\
\text { shell } & I\end{array}$ & $\begin{array}{lc}\text { ü'Enan }^{27} & \text { ye } \\
\text { Ilike } & \text { I'll }\end{array}$ & and swim & $\begin{array}{l}\text { exēu trxol } \\
\text { shell erayfish }\end{array}$ \\
\hline $\begin{array}{l}\text { mi"inan" } \\
\text { I like }\end{array}$ & $\begin{array}{l}\text { trā'wel } \\
\text { trout }\end{array}$ & $\begin{array}{c}\text { ūlètcida } \\
\text { little }\end{array}$ & $\begin{array}{c}\text { hetcē'tcöi } \\
\text { suckers }\end{array}$ & $\begin{array}{c}\text { poq } \\
\text { sm }\end{array}$ \\
\hline $\begin{array}{l}\text { yeko"oxan } \\
\text { I'll kill }\end{array}$ & $\begin{array}{l}\text { ameqe } e^{\prime}-d^{3} \\
\text { dying of hunge }\end{array}$ & $\begin{array}{l}\text { ye'man } \\
\text { let's eat }\end{array}$ & $\begin{array}{l}\text { xatci'la } \\
\text { children }\end{array}$ & \\
\hline $\begin{array}{l}\text { xĕma'non }{ }^{31} \\
\text { I am not eating }\end{array}$ & $\begin{array}{ll} & \operatorname{lu}^{\prime} i n^{32} \\
\text { I drink }\end{array}$ & $\begin{array}{l}\bar{u} \operatorname{mi}^{\prime} \text { ginā'ye } \\
\text { on't you drink }\end{array}$ & $\begin{array}{l}\text { naupi' } \\
(?)\end{array}$ & $\begin{aligned} \text { ěxad } \\
\text { I eoc }\end{aligned}$ \\
\hline $\begin{array}{l}\text { ni'maqai } \\
\text { roast it! }\end{array}$ & $\begin{array}{l}\text { nitcxu'cki } \\
\text { put it in fire }\end{array}$ & $\begin{array}{l}\text { nō'mux }{ }^{33} \\
\text { fix it! }\end{array}$ & $\begin{array}{l}\text { nima'qai } \\
\text { roast it! }\end{array}$ & $\begin{array}{r}\text { nĕxac } \\
\text { coo }\end{array}$ \\
\hline $\begin{array}{l}\text { yĕ'man } \\
\text { let's eat }\end{array}$ & $\begin{array}{l}\text { mūkūwa'tkuna } \\
\text { you did not com }\end{array}$ & $\begin{array}{r}\text { ice } \\
\text { I have }\end{array}$ & $\begin{array}{l}\operatorname{mdan}^{35} \\
\text { listening }\end{array}$ & $\begin{array}{c}\text { xèma'axanan } \\
\text { shall not eat }\end{array}$ \\
\hline $\begin{array}{l}\text { nā'ma } \\
\text { eat! }\end{array}$ & $\begin{array}{l}\text { xèmaktcai'nan } \\
\text { don't want to ea }\end{array}$ & $\begin{array}{l}\text { teu } \\
\text { yo }\end{array}$ & ndan & $\begin{array}{l}\text { pohmu'md } \\
\text { sleeping }\end{array}$ \\
\hline
\end{tabular}

xama'nan qō'ma aqā'deu komatrā'eni tremu'mtxu

not eating grass-seed grass-seed yellowdaisy a yellow flower

tci'ntcei tcexā'ma kowatcu'mxu pè'tsoneu yemo'rna

sunflower-seed a sort of flower (?) (?)

\section{NOTES.}

1 See note 71, text II.

2 The stem is -ko-, to kill. Cf. yeko'xanan, I shall kill you. The suffix -duk is uncertain. Cf. xowa'doknanda, he didn't come back; itexu'tduxta, I hide it away. See following note and note 6, text I.

3 Possibly a case of nominal incorporation, from (hi) teipe, thigh and himai'dukta, earrying back. Cf. nimai'mu, you carry it! imai'muxan, I'll carry it.

4 A nominal form in -eu, formed from a stem -tri- (9) of unknown meaning.

s Apparently from -ko-, to kill. This form is obscure, as the pronominal suffix tea- is not elsewhere used as subject of a transitive verb, but as object. Cf. pâ'ut tea'kotinda, he kills me. The use of -sun which clsewhere has the force of the auxiliary verb "to be," is also unusual.

$B$ The prefix ko- is probably the negative.

7 Probably for i'trirop.

8 The stem is -a- (Cf. -wa-, -owa-). See note 1 , text I.

$\theta$ The stem is -tcaxis.. Generally used as the plural for "to run," another stem, -mum- being used in the singular.

10 Probably from -wa-, -owa- to go. The suffix is undoubtedly -mu-ni, upwards, the -ni being the present tense ending. 
11 The stem seems to be -wa-, with the negative prefix. The usual form of the ending is -guteainan.

12 From -wo-, to ery, weep.

13 Obscule. There is no stem clear, -tok- being elsewhere always united with some regular verbal stem, sometimes with the meaning of back, returning. Perhaps abbreviated in rapid diction from xowato'kgutcaidananda.

14 There is a stem -tcu- which means "to sleep." Cf. yetcu'yegon, I shall sleep. Auother stem -teum- has the meaning of "to marry." Cf. yeteu'mdaxanan, I shall get married.

15 The usual stem for "to follow" is -sim-. Cf. yusi'm, I follow, go with; mexasi'mnatexun, do not follow me!

16 See note 12.

17 See note 69 , text II.

18 The stem is -mai-. The suffix -mu is uncertain, although it apparently indicates direction of motion.

19 The stem appears to be -mi-.

20 The suffix -gu here appears also in such forms as $x^{2} \bar{i}^{\prime} g u$, by and by; curaigu, some time ago. It is probably the negative affix.

21 See note 18.

22 This is apparently xu-xo-da-k-teai-nan. There seems to be a reduplication of the negative prefix, but other examples occur, where -xota- as a stem means simply to wateh, observe, as ixō'tanhun, I watch; ixö'taxanan, I shall look at. Ta-alone has no meaning applicable here.

23 The stem is -go- or -go'na-. Other examples are negō'Ena, talk to me! ; igô'enegon, I'll talk to you.

24 Doubtful. The possessive prefix of the first person singular is evident, but the remainder of the word is not clear. "The stem for "foot" is elsewhere always -po-.

25 The stem here is elearly -xoli-, or -xuli-, meaning bad. Other examples are tco'xoligni, I am bad; qoxoyétutceyi, are ye bad; xuli'da, he is bad; xūli mā'takni, you sing poorly. The suffix -eu may be that used to form nouns from verbs, so that the form here would be "you are a bad-one."

26 Apparently tcu-itc-xē-mun. The stem -xē- occurs also in niěxé'xè sweep! The prefix te- is a very common one, and seems to be similar in its meaning to $t$ - or to-, meaning with the hands, or by force. Other instances of its use are ni-te-xe-tpik, pull out nail; ni-tc-xa-lo, pull out tooth; nu-te-oru-ha, reach up for, etc., etc.

27 The stem is -tcxu- or -texue-. Other instances of its use are ya'texüunan, I wish, want (to eat); mitexü'una, you wish, want.

28 The stem is -xū-, as in ixū, I swim; nixü'yaxana, shall you swim? What seems to be the same stem however is used with several other meanings, as: tcoxū'xanan, I shall blow away; nox $\bar{u}^{\prime}$, whistle!; teō'xun, I am fat; qa $\bar{a}^{\prime}$ xunda, ye are fat, ete. In this latter case, the $u$ is generally short however, but it is certainly long in the other cases.

29 The stem is -mi'ina-. Other examples are: xomi"inanan, I don't like you; mexemi 'inanan, you don't like me. Cf. tcudi'ineman above.

30 Probably ame-qē-da, I am dying of hunger. See note 45 , text II.

31 See note 87 , text II.

32 The stem is lu-. Cf. lūmi'ginaye.

33 See note 36 , text II.

34 Perhaps for mu-ku-wa-tok-gu-nat with the negative affix repeated.

35 The stem is apparently -cem-. See note 10, text IV.

36 See note 82 , text II. 


\section{FREE TRANSLATION.}

A man went out to hunt, but secured nothing. So he earried back his thigh and his intestines, saying, "I am a good hunter." His wives suspected, and did not like him. They said, "We will get some water." Then they ran away. (The remainder seems to be wholly uneonnected, my informant maundering on until she was tired.)

\section{THE THEFT OF FIRE.}

Waida howamda apěxadjit ${ }^{1}$ tcitindosa xāteilc pun Eastwards he went fire-steal Coyote ehild one xĕxadjit ${ }^{2}$ tcitindosa mice'qe himū'kta apisu'xta yuwau'mia he stole Coyote "mieeqe" running fire throwing I go mice'qe yaxateī'ya pa'tcimam $^{3}$ itukmūsun ${ }^{4}$ mice'qe "miceqe" I steal everything I make "mieeqe" yuwau'mxanan mice'qe kimidjunū'mdju ${ }^{5}$ yowamxa'nan I shall go "miceqe" to the head of the river I'll go

yuwaumxa'nan wisèda puntsa'r ětasun mice'qe ā'ma I'll go down river woman many are "mieeqe" plaee yuwaupa'kasun mice'qe a'ma pun xō'nasun ${ }^{6}$ mice'qe I go around "miceqe" plaee one I'll not "miceqe" lurě'djasun xu'mde tcitindō'sa tcusato"mun qā'qatce $\begin{array}{lllll}\text { quick } & \text { (q) Coyote } \quad \text { I ehoke a bird }\end{array}$

nū'wam tcusato"Emun ${ }^{7}$ tcè'tcè nū'wam tcusato"Emun go! I'm ehoking Buzzard go! I'm ehoking

yekoxa'nan nā'tcidut à'wam iwa'mdaxanan ${ }^{8}$ xé'qoqteainan I'll kill you we go I'll stay I won't kill him tci'marut qè'sop ${ }^{9}$ xu'nogidji mice'qe nagi'tcuk ice'mtina ${ }^{10}$ people if die I'll get well (q) "miceqe" (q) listening (q) imitcici'gut" we'lmu mice'qe yowa'mxanan mice'qe I kiek it open quiekly "mieeqe" I'll go "miceqe" tcū'sigasun ${ }^{12}$ mice'qe yě'koxanan mice'qe me'xemī'inanan I'm handsome "mieeqe" I'll kill "miceqe" you don't like me mice'qe megutxu'kni xūwo'ktcainan hamē'u i'tciknan ${ }^{\mathbf{1 s}}$ "miceqe" you don't like me I don't want to come baek food not growing hamē'u pā'tcigun hamē'u idan mitcxūu'na ${ }^{14}$ mowa'mxana food none food (i) do you like you shall go xusi'mkuktcainan tcūgu'tcen iwo'mdaxanan teusi'mxanan I don't want to follow I don't want to I'll stay me shall follow 


\begin{tabular}{|c|c|c|c|}
\hline $\begin{array}{l}\text { cūgu'tcentama } \\
\text { I don't want }\end{array}$ & $\begin{array}{l}\text { he'wu } \\
\text { all right }\end{array}$ & $\begin{array}{l}\bar{a}^{\prime} \text { man } \\
\text { place }\end{array}$ & $\begin{array}{l}\text { xatcilè'gulan } \\
\text { children only }\end{array}$ \\
\hline $\begin{array}{l}\text { cū'nūhulaigulan } \\
\text { old woman only }\end{array}$ & $\begin{array}{l}\text { itrè'igulan } \\
\text { men only }\end{array}$ & $\begin{array}{l}\text { xatcilè'gulan } \\
\text { children only }\end{array}$ & $\begin{array}{l}\text { xotxā'gutcainan } \\
\text { I don't want to stop }\end{array}$ \\
\hline $\begin{array}{l}\text { (?) } \\
\text { (?) }\end{array}$ & $\begin{array}{l}\text { i'nadaxan } \\
\text { I'll wait }\end{array}$ & $\begin{array}{l}\text { I'woxanan }^{15} \\
\text { I'll stay }\end{array}$ & $\begin{array}{l}\text { xowa'xgutcaina } \\
\text { I won't go off }\end{array}$ \\
\hline
\end{tabular}

itricuxai'dēu ${ }^{16}$ tcoxogō'anatan ${ }^{17}$ xowo'ktcainan yowa'mxanan

I'm a chief they don't talk to me I don't want to return I'll go

$\bar{i}^{\prime}$ woxantin iwā'togegon yè'tcuyegon ${ }^{18}$ īwo'mtegon iwau'tegon

I'll stay I'm coming back I shall sleep I'll stay I'll come

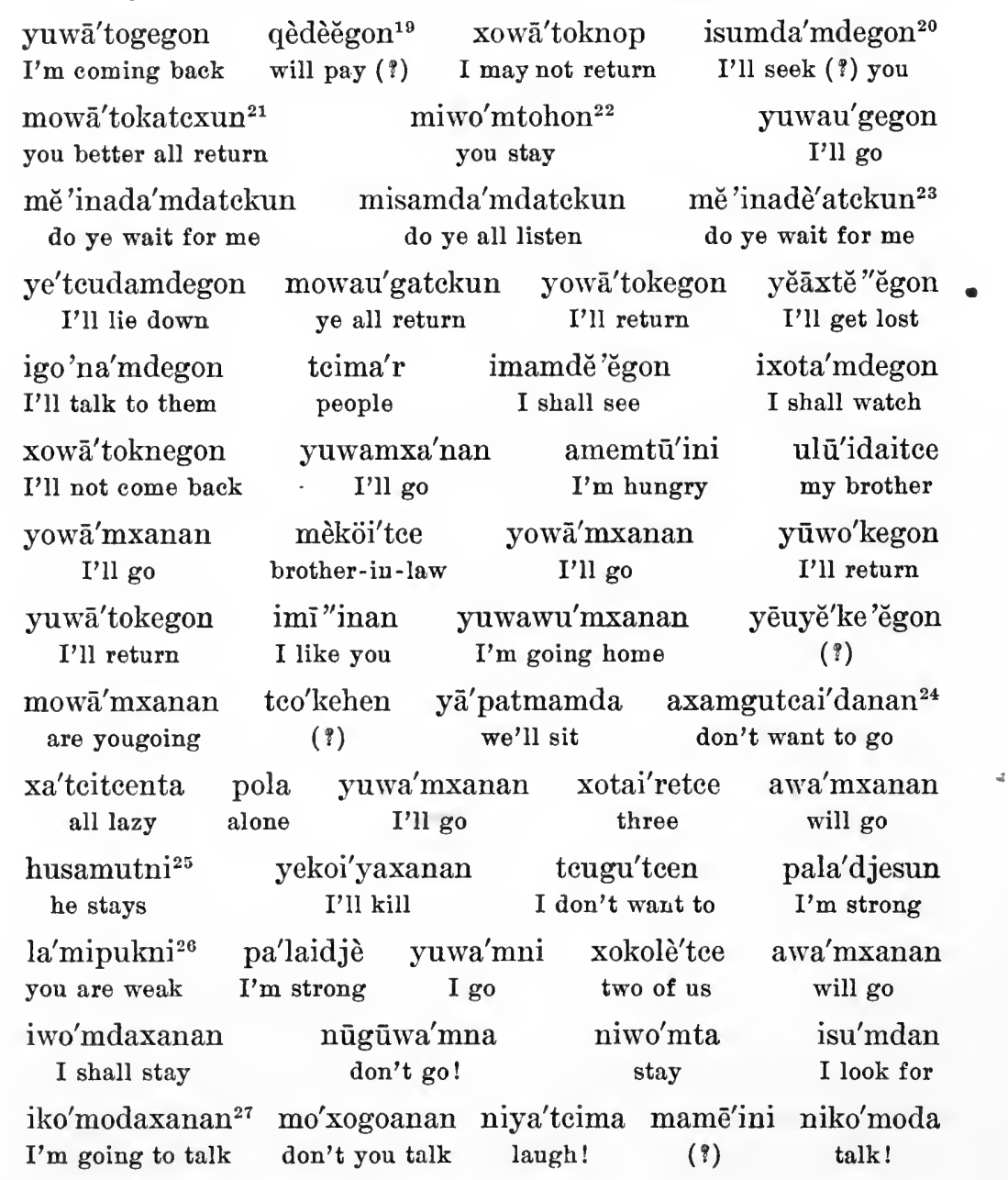




$\begin{array}{cccc}\text { nūwau'm } & \text { nixo'ta } & \text { mugu'tcen }^{28} & \text { yowa'tokxanan } \\ \text { go back! } & \text { look at me } & \text { you don't want to } & \text { I'm coming back }\end{array}$

miwomdatexun mowa'mkunaxana po'mōxana micèmxana you stay aren't you coming back ${ }^{?}$ shall you sleep you'll listen po'la iwa'megonye xokolètce awa'mxanan xā'rale nikī'da alone I shall go two of us will go child carry mugu'tcen ni'ceheda ${ }^{20}$ trē'ūlot $^{30}$ nicehe'm xai'rot $^{31}$ you don't want to take it that big one take it! that little one nikīda yowa'mxanan niceheda po'la iwomtě'ěgon carry! I'll go take it! alone I'll stay

nuwa'mhini tcugu'tcen nōwa'man ameqè'ĕni nohâ'tamda ${ }^{32}$ go on! I don't want to go! I'm dying of bunger look at me!

nitcu'kta ${ }^{33}$ tcugu'tcen nowa'mhini xowa'mgutcainan hī'yĕ take it (?) I don't want to go on! I don't want to go

tce'pini natcū'da nā'xaman hamé'u muputcétceaxini (?) lie down! don't eat! food you are too lazy (?) ūtce'ndakēye miwo'rhanaqe mugu'tcen ā'wam tcugu'tcen

(i) you don't want to let's go I don't want to tcupi'tan xowa'mgutcainan tcupi'tan ${ }^{34}$ ye'tupmoi na'tcidut my foot sore I don't want to go my foot sore (i) we nuhwèaqi yamai'ta imai'ta puntsa'r itri puntsa'riĕ my place (?) woman man wife ulū'idaida miko'modahanxani yowa'mxanan hisi'kni xolè'ini sister you will talk I'm going good bad iko'modaxanan yako'onēwa mo'xoligositce ${ }^{35}$ micche'mxana I will talk we are going to talk you are no good are you going to take him mowa'mxana nūwa'man xosi'mgutcai'nan teugu'tcen are you going go on! I don't want to follow I don't want to xomi"inanan qâqo'n qō'ni niko'muda ko"omitexun I don't like you you kill me I cryout I talk you better cry out anō'tci laibu'kni poimu'ycn yahai'tca ${ }^{36}$ hè'u awa'man (?) weak I'm sleepy let's get food all right we'll go nā'tcidut xowa'mgutcai'nan nowa'man xowoktcai'nan we I don't want to go go on! I don't want to stay mitciumaxa'na madaqa'na ${ }^{3 \tau}$ awa'm yaxo'da nisu'kta ${ }^{38}$ you sing let's go we look look back! himō' aqe'mtuini $^{39}$ lū"mixana nuwā'gai ${ }^{40}$ yuwa'dkun ${ }^{41}$ yes I'm thirsty shall you drink come on! I'm coming 


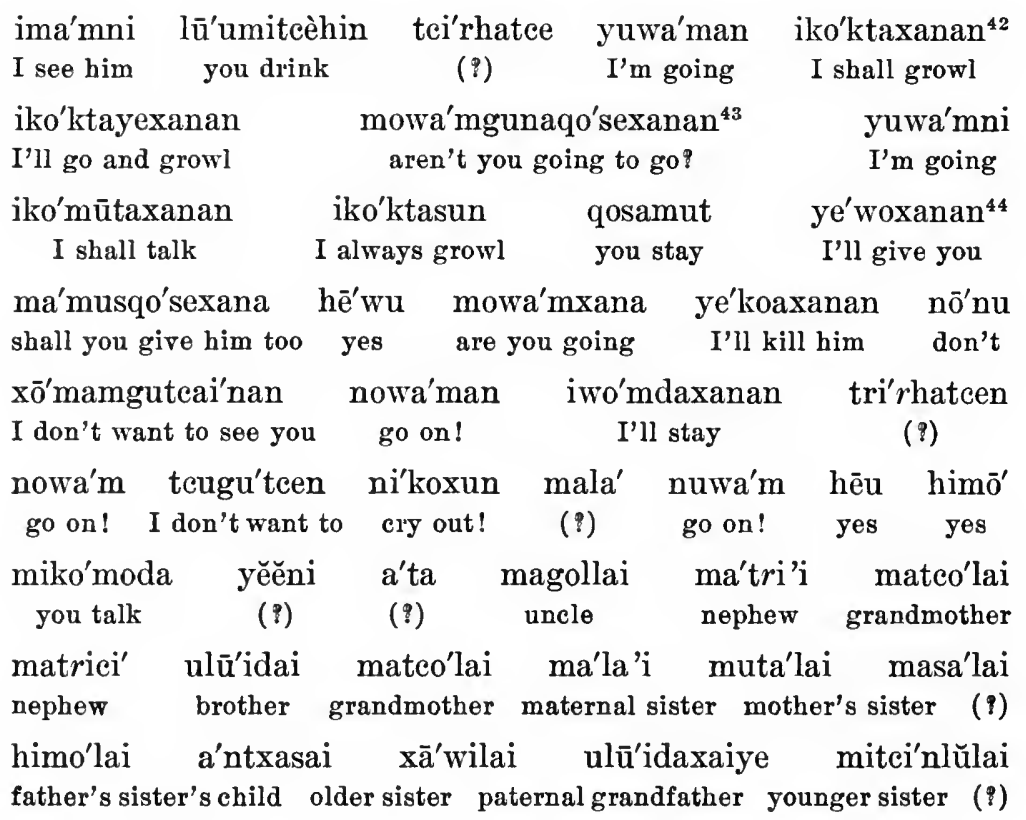

\section{NOTES.}

1 Apparently nominal incorporation. Cf. apisu'xta, below.

2 The usual third personal prefix is here strengthened to $x$ -

3 Cf. patci, what; patcea'mku, something; patcigun, no, none.

4 See note 36, text II. The prefix tu- seems to mean actions done with hands. The stem is puzzling. In several cases, -kmu- seems to mean "to roll,' as nimitci'kmu, roll with foot; niě'kmu, roll with end of stick; nime'kmu, roll with head. There is a common suffix, however, -mu, which seems to have somewhat variable directive meaning and function, as nai'mu, chop; mise'kmu, swallow; ipe'nmu, I lick; iya'tmunip, I lay down a flat thing. If - $k$ - is the stem, its meaning is general, as we have nitcu'ktcan, drive nail; nū'kmak, comb hair, ete.

$\checkmark$ Probably a place name.

- Perhaps related to inam, I touch. Cf. inadaxan, page 350 , third line of text.

7 The stem is -satoE-. The meaning is said to be choking because of rapid motion.

8 The stem is -wam-, -wom-.

$\vartheta$ Conditional suffix.

10 Apparently first person. The stem is -cem-.

11 The prefix mitci-meaning actions with the foot. The stem does not occur elsewhere.

12 The stem is apparently -siga-. Cf. misigä'sun, you are handsome. text II.

13 The stem here, -itci- apparently is the same as -itri-. See note 75,

14 See note 27 , text III. 
15 The $\mathrm{m}$ of -wom- seems to have disappeared here.

16 Chief is itrixaidēu. The pronominal clement here is inserted apparently into the structure of the noun, which may perhaps be analyzed as itri, men, -xai-, stem for to make, create, and the suffix -ēu which usually forms nouns from verbs.

17 The stem is -go- or -go'na-. Cf. note 23 , text III.

18 The stem is -teu-. Cf. yaxuteu'ixan, we shall not sleep; yetcuda'mdegon, I shall lie down, sleep.

19 Cf. idai'goxan, I shall pay; teadai'gunip, we pay.

$20 \mathrm{Cf}$. isu'mni, I follow. The suffix (?) -dam occurs also in such forms as meinada'mda, you look for me; yetcu'damdegon, I'll lie down.

21 The suffix -ate seems to denote plurality. Cf. natcidut $=($ ? $)$ noatci-dut.

22 Probably for miwo'mtaxan.

23 The stem is apparently -inada.

24 The usual form is xowamguteaidanan.

25 Cf. i'samutni, I come back; ya'samuta, we come back.

20 Apparently a case of infixing the pronominal element. Cf. la'tcipukni, I am weak.

27 The stem here is elearly the same as in the next word. It is tempting to regard the -mo as perhaps an incorporated second personal objective element, but there are no other cases to support this view. Cf. nikomoda, talk, speak!

28 See note 14 , text II.

29 The stem is apparently -cehe-. See next line.

30 Shows the use of the intensive suffix -ot, with an adjective.

31 Perhaps related to xara'li, xarüla, baby.

32 Elsewhere -xotam-.

33 The stem -tcuk-, or what appears to be but one such sten, has many meanings. As itcu'ktamnip, I put down a round thing; nitcu'ktcan, drive a nail; teuiteu'kni, I drown; nitcu'klo, pull off button. See note 34, text II.

34 See note 55 , text II.

35 See note 25 , text III.

30 The stem -hai- elsewhere has the meaning of to spit, to vomit.

37 The stem is tak-. Cf. yetakni, I sing; ya'tak, we sing.

38 This stem does not oceur elsewhere. To throw is -sux-.

39 Cf. ame'mtuini, I am hungry.

40 Perhaps for -wauk- contracted from -watok-

41 Perhaps for yuwa'tokun.

42 By "'growling"' was meant, it was explained, "talking big."

43 The suffix -qose apparently means "also, too."

44 Meaning doubtful. The stem -wo- elsewhere means to cry, whereas -wo- is the form used in the singular for "to sit."

\section{FREE TRANSLATION.}

Coyote went eastwards to steal fire. There was one child only of the owner at home. Coyote stole the fire, and ran off down river, where there were many women. He ran so fast that he choked, then surrendered the brand to a bird, who did likewise, giving it up to the Buzzard. (The latter portion of this tale also is apparently extremely confused, and it seems impossible to make any connected sense out of it.) 


\section{A MYTH.13}

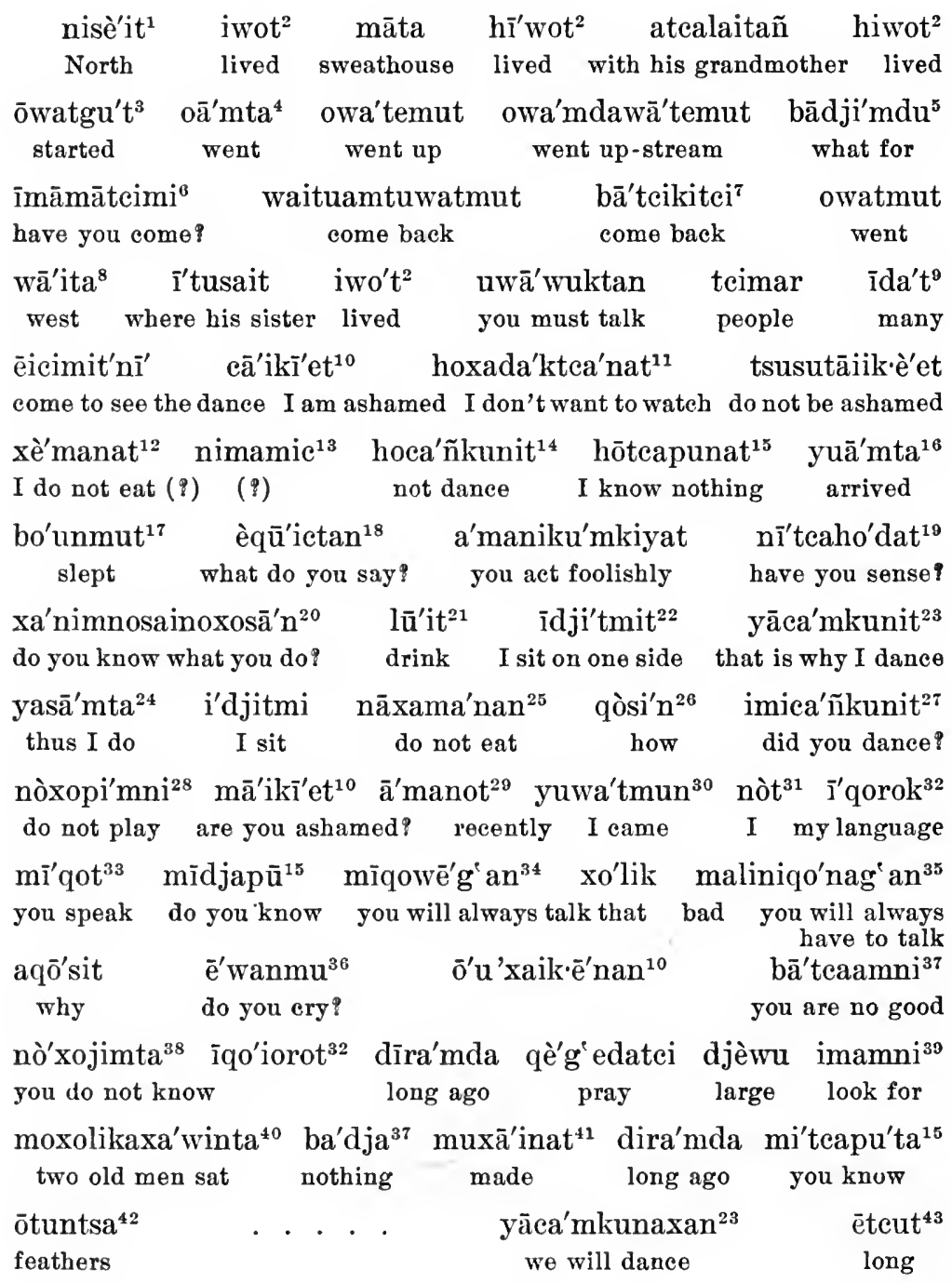

13 Obtained in 1901 by Dr. A. L. Kroeber from Doctor Tom, the Chimariko informant mentioned below in connection with the vocabulary. While the thread of the story cannot be made out from the disjointed narrative, it evidently is a myth. Doctor Tom passes among the Indians as being more or less out of his mind. As he is old and knows practically no English, the translation had to be given by him in the Hupa language, with which Dr. Kroeber is unacquainted, and translated into English by a Hupa. While loose, it is however shown to be approximately correct by the analysis that can be made of many forms. 
$y^{a} x^{\prime} \operatorname{taxan}^{44}$ mukice'ta ${ }^{45}$ onienema'ri naijidiji'tmin ${ }^{40}$ we will see you do not wish to go once more we must go then they stay

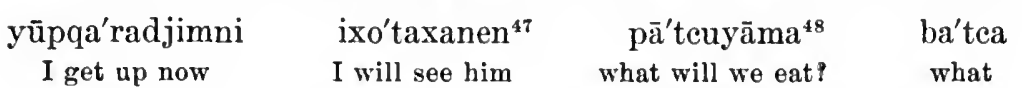
qo'tsesekesa'inen yacamkunit nāecia'racimni bā'ikinaesan must we do? we dance I must stretch myself I will dance about hò'tceu yūtiwièni nimiina't ${ }^{49}$ xo'miinana'n ${ }^{49}$ nè'g'ada'txumū'i fall in water you like I do not like yourself

\begin{tabular}{|c|c|c|c|c|c|}
\hline $\begin{array}{l}\text { è'yit } \\
\text { ance }\end{array}$ & $\begin{array}{c}\text { imitsamā } \\
\text { hold! }\end{array}$ & & ata & $\begin{array}{l}\text { mut } \\
\text { surr }\end{array}$ & $\begin{array}{l}\text { nicikio't }{ }^{50} \\
\text { make a fire! }\end{array}$ \\
\hline $\operatorname{cota}^{\prime} x^{47}$ & $\overline{\mathrm{i}} \mathrm{ma} \bar{x}^{\prime} \mathrm{m}^{39}$ & qòsni'ni' ${ }^{20}$ & lādjin ${ }^{51}$ & xèpakī'n & bōè'mxan ${ }^{32}$ \\
\hline me look! & I see & how & I am tired & I am dizzy & leepy \\
\hline $0 \cos 53$ & hinì' & $\begin{array}{l}\text { ixotèmd } \\
\text { do not ca }\end{array}$ & $\begin{array}{l}\text { hè'n }{ }^{54} \\
\text { look }\end{array}$ & g'eta & $\begin{array}{l}\text { tcimexáa'ita } \\
\text { you make }\end{array}$ \\
\hline
\end{tabular}
nitxä'xana $^{56}$ lā'djin qòsi'ni mica'ñkunit ${ }^{57}$ īwonhi'ni ${ }^{58}$ stop! tired how you will dance I stay here

xō'sini qò'sini lāwitama ${ }^{51} \operatorname{ciraku}^{59}$ mū'amta $^{60}$ bātcaxā'hatan ${ }^{61}$ what makes you tired already you start I have nothing

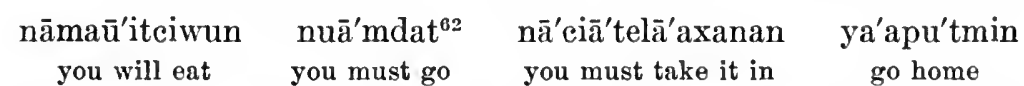
$\bar{a}^{\prime}$ manidja'pūi ${ }^{63}$ nitcò'u $u^{64}$ qò'sin nitcò'u tcī'sagkun ${ }^{65}$ tcaa'wèita $^{66}$ you know stretch yourself how you stretch I am exhausted I am angry dāwuxton yūtsu'nta ${ }^{67}$ djuklū'uxut ${ }^{68}$ lādjidā'mda ${ }^{69}$ eicā'mkuni do not jump in jump in become tired I dance

lā'djin yè'matsisin miitcā'exotax ${ }^{70}$ nupu'o $\bar{a}^{\prime} w a m t u^{71}$
tired I want to eat look at it what for? with mouth mikot $^{33}$ xa'ni mikoxa'nat ${ }^{72}$ naā'wutbimni ${ }^{73}$ yuaka'nat you talk by and by you will talk we must play

nācibi'mdaxanan ${ }^{73}$ ōtsumnīis7 nāmāata(n)hèi nā'icukudjhen ${ }^{74}$ we must play jump in do you pick berries do not want to nü'tsuxunmu ${ }^{75}$ nitxa'nemaexa ${ }^{78}$ nīeiè'i nacbā'tcikum ${ }^{77}$ jump into the ground your knees are sore I do not want i'xotama'ri bī'maranū'texō ā'tcawè'it ni'wekdapmu ${ }^{78}$ qocum I want to see you mash it are you afraid bring him out! how tsi'rokon $^{79}$ i'mamni e'xaini' no'ot qè'xeta ${ }^{80}$ ima'mta $\begin{array}{lllll}\text { did I talk I see I make I I make I see } & \end{array}$ tcè'mta ${ }^{81}$ ixo'tat ica'mxu'nit gū'utcèet ${ }^{82}$ hēmā'itat ${ }^{83} x^{\prime} \bar{a}^{\prime}{ }^{\prime}{ }^{\prime} \bar{u}^{84}$ always I see I dance do not want to earry him soon 


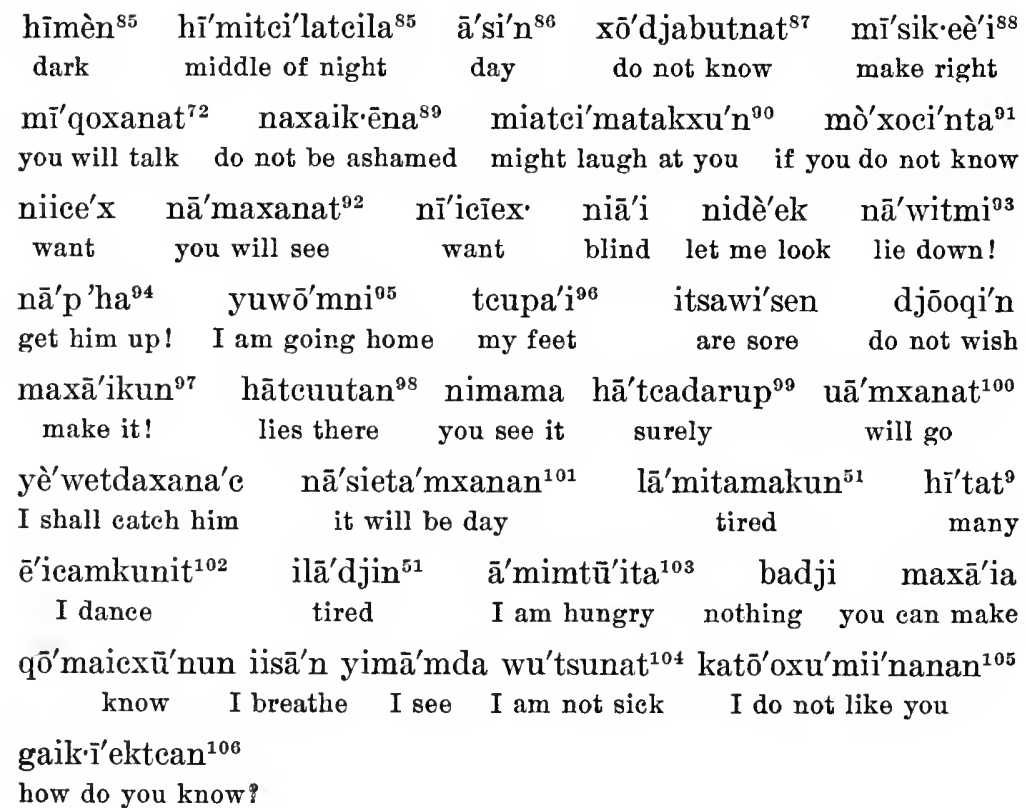

\section{NOTES.}

1 Perhaps for wisē-da, down-stream, i.e., north.

2 -wo-, to sit, to stay. Cf. hiwotīnda, he sits.

3 -wa-tok, -owa-tok, return(q). Cf. muku-watku-nat, you did not eome, page 347, line 8 of text.

4 -wam-, -owam-, to go; -ta, participle.

${ }^{5}$ patei, what; -mdu, instrumental.

6 -mat-, to find; -mamat-, alive. Cf. ma-i-mat-ni, $I$ am alive.

7 Cf. ante, badji-mdu.

8 wai-da, west or up-stream.

9 Cf. ètasun, many.

${ }^{10} \mathrm{c}-$, probably for tc-, I; -aikie-, ashamed.

11 Cf. note 22 , text III.

$12 \mathrm{Cf}$. xemanon, page 347 , line 6 of text.

13 Perhaps ni-, imperative, and -mam-, to see.

14 ho-, negative; -samxu-, to dance.

15 ho-, negative; teapu- probably -trahu, to know.

16 Cf. note 4.

17 -po-, to sleep. Cf. po-anmu, you sleep.

18 Probably -qu-, -ko-, -komo-, to talk; e- perhaps interrogative. Cf. i-mi-canku-nit, did you danceq; a-qōsit, why \&; e-wanmu, do you ery?

19 Probably -teaho-, for -trahu-, to know. Cf. ante hotcapunat.

20 Perhaps xani, by and by;

21 -lu-, to drink. Cf. page 347, line 6 of text.

$22 \mathrm{i}$-, I; -tcit-, to sit; -mi, the verbal suffix, down; -t probably the intensive suffix, -ut, -ot, -t. 
23 ya-, we; -samxu-, to dance.

24 Probably -sam-, to listen( ( ). Cf. mi-sam-damdatckun, page 350, line 8 of text.

25 na-, second person imperative; $x^{-}$, negative; -ama-, to eat; -nan, verbal suffix. Cf. xèmanat, ante line 6 .

26 Interrogative stem qo.

$27 \mathrm{i}$, perhaps interrogative. Cf. note 18. tense.

28 no, imperative; xo-, negative; -pim-, to play; -ni, suffix of present

29 Cf. aman-itri, young; aman-inhu, new. Perhaps also a'maniku'mkiyat ante, line 7.

${ }^{30} \mathrm{y}-$, for i-, I; -uwat-, -owat-, to come.

31 Contracted from nōut.

32 Evidently from the stem -ko-, -qo-, -go-, to speak. The form is obscure, as the possessive -i, my, is always suffixed.

$33 \mathrm{mi}-$, you; stem as in the previous word.

$34 \mathrm{mi}-$, you; -ko- to talk; -we, perhaps for -wet, continuative; -g' an for -xan, future.

35 It is possible that the first portion of this word is the Wintun pronoun for the second person dual, malin. A Hupa word is inserted in the following text.

36 Cf. ewo'imamni, I cry.

37 Cf. pā'tceam-ku, something (nothing 8 ).

38 no-, imperative; xo-, negative; -ta, participle. The stem -jim-(tcim) does not occur elsewhere in the material collected.

$39 \mathrm{i}-, \mathrm{I}$; -mam-, to see; -ni, present tense.

40 Obscure. -xoli, may be xuli, bad; xawin, old. Cf. note 25, text III.

$41 \mathrm{mu}$, you; -xai-, to make.

$42 \mathrm{hu}-\mathrm{tu}$, its feather.

43 Cf. hitcun, long.

44 ya-, we; -xota-, to sec; -xan, future.

45 Cf. -gutce-, -gutcai-, do not witsh, as in tcu-gutcen, I do not wish.

46 na-, imperative; -jid-(tcit) (reduplicated), to sit. So "do ye sit down one after the other''(?).

$47 \mathrm{i}$, I; -xota-, to see; -xan, future.

48 patci, what; $y-, I$; -ama-, to eat.

$49 \mathrm{ni}$, second person imperative; -mi'inan-, to like.

50 -cikiot perhaps for -cekta-, to build fire.

51 la-, weak, tired; -tci, I; -in, incompleted action. In other instances, -mi, you.

52 -po-, to sleep; -xan, future. Cf. poimni, I sleep.

53 Cf. ixota'x, line before.

54 Cf. note 45 .

55 tci-, I; me-, actions done with hand( 9 ); -xai-, to make; -ta, participle.

$50 \mathrm{ni}$-, second person imperative; -txa-, to stop; -xan, future.

$57 \mathrm{mi}-$, you; -samxu-, to dance. The phrase "how you will dance", seems to mean "thus you will always dance in the future."

58 -won-, for -wom, to stay.

59 ciraku, curaigu, from cur-, long ago, and the negative -gu.

$00 \mathrm{mu}-$, you; -wam-, to go; -ta, participle.

61 Seems to contain the negative.

$02 \mathrm{nu}$, second person imperative; -wam-, to go. 
63 Cf. note 29. Perhaps -pu is the interrogative suffix. Cf. mexadjipu, have you stolen?

$64 \mathrm{ni}-$, second person imperative; -tco-, ef. -tcu-, to lie down, to sleep.

65 tei-, I; -sag-, ef. -sax-, to eough(?).

66 tea-, I; -awè-, angry; -ta, participle.

e7 -tsu-, -tsum-, -tsun-, to jump.

$68 \mathrm{dju}-$, teu-, I; -klu-, to fall.

69 Cf. note 51. -dam is a verbal suffix of uncertain meaning in this case. Cf. měinadamda, you look for me.

70 Contains - xota-, to look, watch.

${ }^{71}$ ha-wa, his mouth; -mdu, instrumental. line 9 .

72 Or else from -ko-, to kill. Cf. ye-ko-xan-an, I'll kill you, text IV,

73 - pim-, to play.

74 Cf. teugutcen, I don't want to, text IV, line 15.

$75 \mathrm{nu}-$, second person imperative; -tsu-, to jump; -xun, verbal suffix meaning into; -mu, verbal snffix of uncertain meaning. Cf. naimu, chop; nitupmu, roll along, ete.

76 hi-txanemaxa, his knee.

77 Cf. pateigun, no.

78 ni-, I; -whek-, to push; -tap, out of.

79 Cf. iqorok, ante line 10.

80 -xe-, for -xai-, to make.

81 tcem-da means "across a stream."

82 Cf. note 74.

83 Perhaps he- is the negative, xe-; -mai-, to carry.

$84 \mathrm{xani}$, by and by, and -gu, the negative. Cf. note 59.

85 himi, hime, himokni, night. The -n appears in hime-n-ala, moon.

86 asi, asse, day. Cf. asi-n-ala, sun.

87 xo-, negative; djabu- (tcapu ante) for -trahu-, to know.

88 hisikni, hisiki-, good; -eèi perhaps -eye, reflective.

89 na-, second person imperative; $x-$, negative; -aikie-, ashamed.

$90 \mathrm{mi}-$, you, object; -yatei-, to laugh; -xun is either the future -xan, or the continuative -hun.

91 mo-, you; - $\mathrm{xo}$, negative; -cim-, -cem-, to listen; -ta, participle.

$92 \mathrm{n}$-, second person imperative; -ama-, to eat; -xan, future.

93 na-, second person imperative; -mi, -tmi, verbal suffix, down; -wi-, ef. hawi'ida, driv deer; ha-wi-maxan, poke hole in sheet of paper.

${ }^{24} \mathrm{n}$-, second person imperative; -ap-, to get off horse; -ha, up.

${ }^{95} \mathrm{y}^{-}, \mathrm{I}$; -owam-, to go.

of teu-, my; hu-po, his foot.

97 ma-, perhaps for na-, second person imperative; -xai, to make.

98 -tcu-, to lie down, sleep.

99 -up, intensive.

100 -owam, to go; -xan, future; -at( (q) for -ut, -ot, intensive.

101 asi, day; -xan, future.

102 èi-, for i-, I.

103 amemtu-, hungry; -i-, I; -ta, participle.

104 The final -t, -at, probably the intensive -ut, -ot is of frequent occurrence.

105 xu-, negative; -mi'ina-, to like; -nan, verbal suffix.

106 -aik.ie-, ashamed. 
VI.14

yè'ma ${ }^{1}$ íwaxanin $^{2}$ é'kocxanan ${ }^{3}$ tci'mitcakun kolalai yua'mni

I eat I will defecate I will urinate enough sick I go

nīmā'ama nidjidmaga'na ${ }^{5}$ nīpā'itca ${ }^{6}$ bā'tcikū' ici'cnū'xni i'sā'n $\bar{n}^{7}$ you see say so pick up no bring wood sleepy

xa'nisama $^{8}$ xe'ma $^{\prime 8}$ dji'txanak ${ }^{10}$ hōsetdjanīwu' nīmìna ${ }^{\prime 11}$ hīsī'ktă ${ }^{12}$

soon head blanket sick behind good

hī'edāt hīdjuknīis hī'djutbitan ${ }^{14}$ nādja'ldan ${ }^{15}$ nāxo'cxu ${ }^{16}$ misă'gū $^{17}$ fall in drown a spring rock cut put in mouth nīsā'wkă hītāi ${ }^{18}$ kōon $^{10}$ hitèiwāmda nīxota ${ }^{20}$ muxu'lika ${ }^{21}$ āwa'm put in mouth much talk go down look! say go nūakta ${ }^{22}$ xā'yĕ djè'u ${ }^{23}$ miwū' xumāmnan ${ }^{24}$ yacangxu'ni ${ }^{25}$ go ${ }^{\circ}$ small large give do not see let us dance

yāxu'tcu nīei'nātē'i nō'sexana'nº nīmāma' nāeco yōku'n go to bed cover me! suckle me look make basket nè'wu pā'dju nuwī'e $\mathrm{e}^{28}$ xoda'la ${ }^{29}$ nitcxè'm ${ }^{30}$ nitcxe'ako ${ }^{30}$ give enough earry little drag! stop!

mītcapu $^{31}$ hī'wana'dan nā'k!o badxa'la nuxu'māmnan ${ }^{24}$ chew go on seetwo enough not see

yōkumramni'p $p^{32}$ mitcxa'ni ${ }^{33}$ yèko' ${ }^{34}$ tcāwīn mèxo'tan ${ }^{35}$ run small kill I fear on

yutsuxa'mni ${ }^{30}$ yuwā'wukne ${ }^{37}$ bō'anmu ${ }^{38}$ nā'waxāii ${ }^{38}$ muxuliñni ${ }^{40}$

fall down I come back you sleep yourmouth is small you are ugly xâ'se hitema' nimama nimaitce ${ }^{41}$ yamat imā'mta nīmā'mxanat grass (?) cook see food I see you will see $\begin{array}{ccccccc}\text { nâot } & \text { xu'noìta }^{42} & \text { nintji }^{43} & \bar{a}^{\prime} \text { ma } & \text { Ixā'ita } & \text { xo'se } & \text { hīmōu } \\ \text { I } & \text { go up } & \text { your nose } & \text { earth } & \text { I made } & \text { grass } & \text { yes }\end{array}$ exāini'p ${ }^{44}$ yè'kōn ${ }^{34}$ nâjidi'li nâxâa $\hat{a}^{45}$ huwa'm xa'ni I make I kill play flute! stop go soon

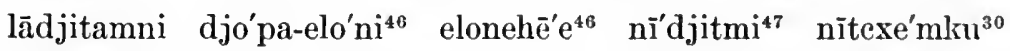
tired too hot hot sit down! drag!

djemta nuamatcxun ${ }^{48}$ wèsatk!â'se yū'tsū'txamu ${ }^{36}$ hawalla ${ }^{40}$ across river go! sleepy fall down who are you lā'mitama nāmaexuni xālalā'idji'ni dīramda dīramd ua'kdat ${ }^{50}$ tired around go home long ago long ago came

\footnotetext{
14 Part of a text obtained in the same way as the last.
} 


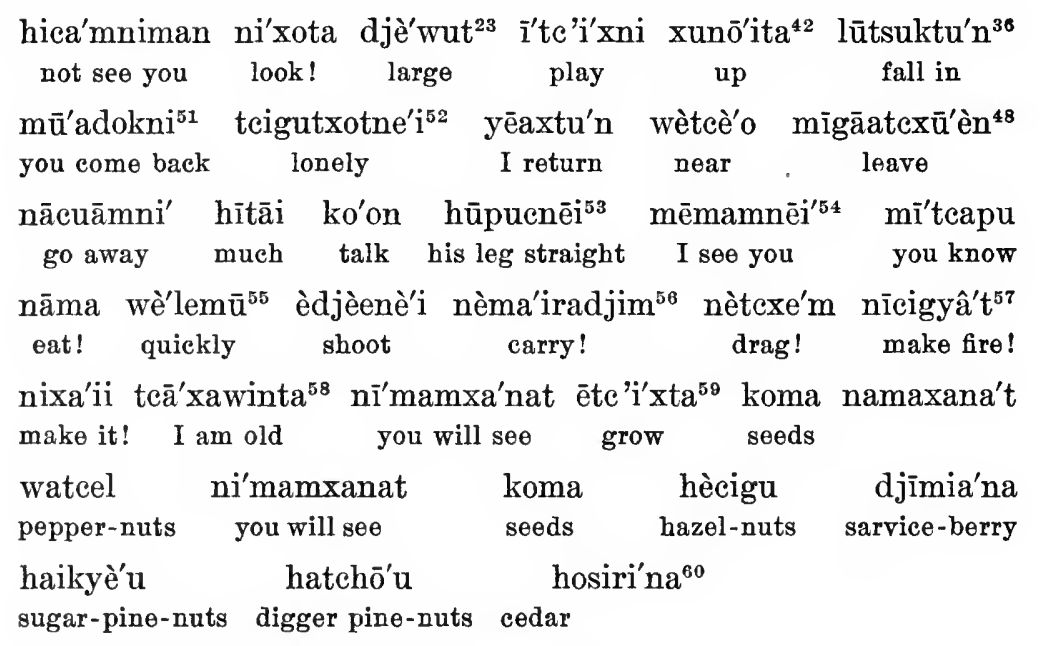

\section{NOTES.}

$1 \mathrm{i}$-, I; -ama-, to eat.

$2 \mathrm{i}-\mathrm{I}$; hi-wax, his excrement; -xan, future; -in, incomplete action.

3 e-que, his urine.

$4 \mathrm{ni}$-, second person imperative; -mam-, to see.

$5 \mathrm{ni}$-, second person imperative; -tcit-, to sit; -gan, -xan, future.

${ }^{6} \mathrm{ni}$, second person imperative; -pa-, perhaps -pa-, to smoke.

7 Cf. iisan, text $V$, next to last line.

8 xani, soon, by and by.

$\theta$ hi-ma, his head.

10 teitxa, blanket.

11 Cf. himinatce, behind; himinna, back.

12 hisiki-; hisikni, good.

13 -tcuk-, a stem of varied meaning. Cf. nitcuktan, drive nail; nitcuktapku, take out a round thing; itcukar, drowned; text I, line 7.

14 -tcut, to strike( (8); -pi, -tpi, suffix, out, out of.

15 Cf. tcaldan, metal.

16 Cf. tca-xos-amu, I yawn.

17 Cf. note 65 , text V.

19 Cf. note 9 , text $V$.

19 From -ko-, to speak.

$20 \mathrm{n}$, , second person imperative; -xota, to look, watch.

21 Cf. note 40 , text V.

$22 \mathrm{nu}$-, second person imperative; -wak-, to come; -ta, participle.

23 djèu, tcèu, trèu, large.

$24 \mathrm{xu}$-, negative; -mam-, see; -nan, verbal suffix.

25 ya-, we; -samxu-, to dance; -ni, incompleted action.

26 no-, second person imperative; -sex-, cf. -sek-, to swallow; -xan, future.

27 Cf. pâdju, grizzly-bear.

$28 \mathrm{nu}$-, second person imperative; -wi, cf. ha-wi'-ida, drive deer. 
29 xodallan, poor.

${ }^{30} \mathrm{Cf}$. teu-itexē-mun, page 347 , line 2 of text.

$31 \mathrm{mi}$-, you; -tca-, to ehew; -pu, perhaps interrogative.

32 Cf. ( 9 ) nipe-ram-ram-, to taste.

33 Cf.(9) ni-texa-lo, pull out tooth; itexa-posta, Dyer's ranch .

34 ye-, I; -ko-, to kill; -n, incomplete action.

$35 \mathrm{mi}-\operatorname{xota} \cdot \mathrm{n}($ ( ) $)$.

36 -tsu, to jump. Cf. note 67 , text V. But hu-tsu-tmin, fly down; -xam, suffix, down; -ni, incompleted action.

$37 \mathrm{y}$, I; -owak, to come, here apparently reduplicated; -ne, -ni, incompleted action.

$38 \mathrm{Cf}$. note 17 , text V.

39 ha-wa, his mouth.

$40 \mathrm{mu}-$, you; -xuli-, bad. Cf. note 21 .

41 Cf. -mai-, to carry.

42 xunoi-da means west or north.

43 A Hupa word. The Chimariko would be mo-xu.

$44 \mathrm{e}$-, for i-, I; -xai-, to make; -ni, incompleted action; -p, intensive.

45 Cf. i-txa-Eni, I stop.

46 elox-ni, elo-ta, hot.

47 ni-, second person imperative; -teit-, to sit; -mi, suffix, down.

$48 \mathrm{Cf}$. mo-watok-atcxun, page 350 , line 7 of text.

49 awilla, who.

50 -wak-, to come; -da, participle; -t, intensive.

$51 \mathrm{mu}$-, you; -atok-, -watok-, return; -ni, incompleted action.

$52 \mathrm{Cf}$. tcigule, we all. Or more probably, tci-, I; gu-, negative.

53 hu-po, his leg.

54 me-, for mi-, you; -mam-, to see; -nei, cf. preceding word, and, post, èdjè-nèi.

55 welmu, quickly.

56 ne-, second person imperative; -mai-, to carry.

$57 \mathrm{ni}$, second person imperative; -cekta-, make fire.

58 tea-, I; -xawi-ni, old; -ta, participle.

59 Cf. -itri-, -itci-, to grow, a man.

${ }^{60}$ Cedar is hâtsinaktea; hosu, xosu is yellow-pine nut. The tree would be hosu-na.

\section{SENTENCES.}

puntsalot hamtatinda citcelot puntsalot himitcitinda tcimal citcela hapukēini hemxolla

mimitcitida citcela

hipuimuktinda citcela

imitcitinda

memiteitida

tcumi 'inatinda

qonowectinda

imitcitxanan citcelot

nitcut citcela woman whipped dog man kicked the woman dog caught the jack-rabbit

you are kicking the dog they are pinching the dog I am kicking him you are kicking me he likes me ye are whipping me I shall kick the dog hit the dog! 


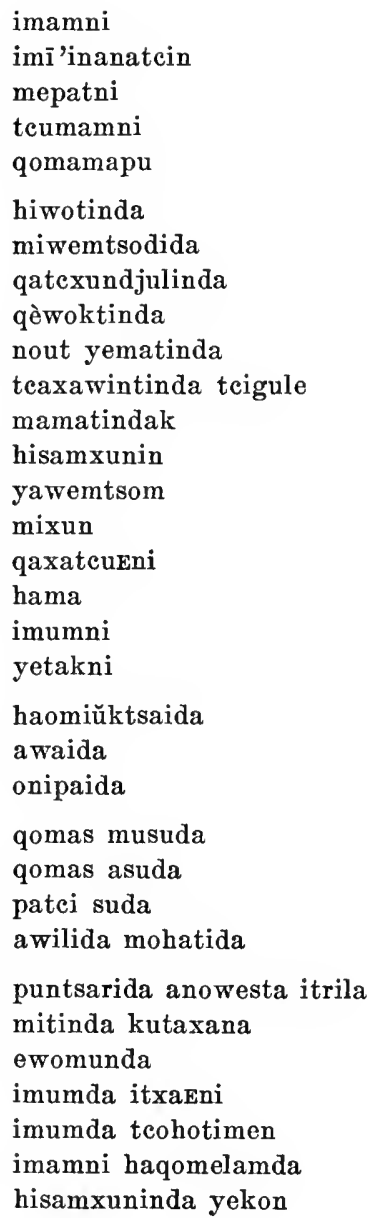

I see thee, him

I like ye

you are poking me

he sees me

do ye see me

he sits

you gamble

ye are thin

he is sick

I eat

we all are old

you ate

he dances

we gamble

you are fat

ye are short

he eats

I run

$I$ sing

his hat

his house

his pipe

who are you

who is he

what is this

who shot you

woman whipped boy

are you going to keep it?

still erying

I stop running

while running, he shot me

I saw him running, hurrying away while he was dancing, I killed him

\section{VOCABULARY.}

The following English-Chimariko and Chimariko-English vocabulary is based on the author's notes. To these are added materials from the following sources.

Words marked with an asterisk, *, are from Powers' Tribes of California, pages $474-477$, slightly transeribed to conform to the present orthography. Those marked with a dagger, $\dagger$, were obtained by the author, but are given in identical form by Powers, allowing for the fact that Powers does not distinguish $\mathrm{k}$ and $\mathrm{q}$ and writes no glottal catches. 
Words in parentheses, ( ), were obtained by Dr. A. L. Kroeber from the informant Friday in 1902, and those in brackets, [ ], from Doctor Tom, an old feeble-minded Chimariko at Hupa, in 1901 and 1902. Many of the more common words, having been obtained by Dr. Kroeber in a form identical with that recorded by the writer, are not separately given.

Words marked with $\S$ were obtained by Dr. P. E. Goddard from Mrs. Noble, a daughter of Mrs. Dyer, in 1902. A considerable number of other words also obtained by Dr. Goddard, in a form identical with that recorded by Dr. Kroeber or the writer, are not specially marked.

\section{ENGLISH-CHIMARIKO.}

Abalone, sulhim

Abandon, -txax-

Accompany, -sim-

Acorn, yūtri, (tcxupun)

Acorn (black-oak), [(muni)]

Acorn-bread, tcěneu

Acorn-meal (leached), pāci

Acorn-meal (unleached), yōma

Acorn-soaking place, matciya

Acorn-soup, hâpēu

Acorn (shelled), ihitci

Across-stream, tcem-da

Again, (tabum)

Alder, pakto'ena

Alive, -mamat-

All, (kumitcin) $\dagger$

Alone, pola

Angry, -awè-

Ankle, hi-kxanlèdě, hi-txanlede

Ant (black), pèlo'a

Ant (red), t'amitcxul

Antlers, ho-wec

Anus, hi-wi

A rm, hi-tanpu, [hi-tcanpu], hi-tcanpo*

Arm-pit, cilēitcūmuni

Armor, t'ummi

Arrow, sa'a

Arrow-flaker, atcibuksa

Arrow-point, qāku

Ashes, matripxa, matripa

Aunt (paternal), ulūida-i(?)
Aunt (maternal), mālai-i, mūtala-i

Autumn, asōdiwukni, nomatci*

Awl, cibui

Axe, haimuksa, hamukteu*

Baby, xarŭlla, xalǔla, (xalala), halalla*

Back, hi-mina

Bad, xuli, holi-ta*

Bark (of tree), hi-pxadji, hi-patei*

To bark, wowoin

Basket-hat, haōmiŭksa (haamiaktea)

Basket (burden), sangen, (cānkeen)

Basket (cooking), poquela

Basket (mortar), hā'eu

Basket (open tray), powa

Basket (sifting), atanisuk

Basket (spoon), kalǔwěè

Basket (storage),( opumaktea)

Basket (tray), p'unna

Bat, teemxatcila

Bachelor, puntsariěcku, ōĕlŭlla

Beads (disk), mendrahě

Bear (black), tcisamra, (djicamla), [djisamara], tcisamrha*

Bear (grizzly), pâdju, (potcu)

Beard, (hu-puteu-n-xame), [habudju-n-xami], o-puteun-haına*

Beaver, wisilla

Bed, hatciinarutsa

Beetle, qō'a 
Belly, hu-trunèu, (hu-tceneu), u-teuniwa*

Belt, hi-ca'amatat

To bend, -koru-

Bird, (di 'la), tirha*

Bitter, hemüdadjan

Black, tcělēi, tceli-t*

Blackberry, xamoana

Blackbird, tira-cela, tēila-tcele

Blanket, teitxa

To bleed, södrè-

Blind, -sukxomen, -xosanmun

Blood, sötri, citrqi, sitsö*

To blow, -hus-, -xuc-, -kos-, -xu-

Blue (q-cf. blood), sötě'i

Bluebird, ipūitella

Blucjay, tsokokotce

Board, ho'ěu

To boil, -potpot-, -dum-

Bone, hu-txun

Born, -dah-

Bow, xâpuněu

Boy, itrilla, itcila $\dagger$

Brain, hi-ni

To break, -kat-, -tcex-, -xötös-

Breast, hu-si*

Breast (woman's), sī'lēye, sirha†, [cīa]

To breathe, -saxut-

To bring, -hak-, -hek-

Brother, ulūida

Brother-in-law, meku-i

Buckeye, yonot

Buckskin, teirhuntol

To burn, -ni-, -maa-

To bury, -tot-

Butterfly, tsamila

Button, hi-punaktea

Buzzard, tcètcèi

By and by, punuslala, xani, tamini

To eall, -kō-, -kokō-

Cane, hutatat

Canoe, mūtumma, motuma*

To carry, -mai-, -ham-, -qi-, -xŭ-

Caterpillar, xawin, qawin

Cats-cradle, axādēu

Cedar, hâtsinaktea, hâtinaktsana

Chair, hi-woanadatsa

Chaparral, puktea'Ena, axaena
Cheek, hu-tananundjatun

To chew, -teatci-

Chief, itra-xai-dēu, itci-haitie*

Chimariko, (tcimaliko)

Chin, tsuna, wětu

Chipmunk, pipila, wisilla( ( )

Civet-cat, kakesmilla

To clap hands, -putata

Clean, mata'i

To clear (weather), -tcemux-

To climb, -ar-

Clock, ixodaktea

Cloud, hawēdam, [āwetama], (awatamaxni)

Clover, kâteu

Coals, kōwa

Cold, eco-, (xatsa), eso-ta*

Comb, tanatei

To comb, -kma-

To comb, -watok-, -wok-, -owak

To cough, -sax-

Cousin, antxala-i

Country, ama

Coyote, tcitindōsa, (maidjandela), [maidjandera]

Cradle, wenteu

Crane, kisum, kâsar

Cray-fish, trxol

Crooked, p'qělě'in

Crow, wa'da, wa'la

To ery, -wo-

Cup and ball, hīteumūdadehu

To cut, -kut-, -lolo-

To dance, -samxu-

Daughter, masola-i, maisula-i*

Daughter-in-law, teu-simda

Day, assĕ, $\dagger$ [asi]

Deaf, hukēnan

Deep, teuxunmin (?)

Deer, ā'a, aa*

Deer (buck), (xuwetci)

Deer (doe), (yetcawe)

Deer-brush, qapuna

Deer-trap, haxaktea

To dent, -kxol-, -tran-

Dentalia, hatcidri, t'ödödöhi [(ahateu $)]$

"Devil"' (prob. sorcerer), himisanto, (himisamtu)

Dew, qoido 
To die, -qè-

To dig, -po-, -tsik-

Digging-stick, tsunana

To dip up, -hedo- (

Dirty, teelě'in

To dismount, -ap-

Dog, eitcella, sitcela†

Door, wěssa

Dove, yūura

Downwards, tranmida

Down stream, wisèda

To drag, -texē-

Dragon-fly, hiteinemnem

To dream, -maka-

To drink, lū-

To drive, -sik-

To drop, -lul-, -lus-, -lurim-

To drown, -tcuk- ( 9 )

Drum, hisamquni

Dry, atcxumni

Duck, xaxatcèi, hahatce* (= mallard)

Dull, tono'i

Dust, matcitsxol, matrepa

Eagle, wemer, tcāwitcau, (djāwidjau )

Ear, hi-sam, hi-cam*

Earth, [ama] $\dagger$

Earthquake, amitcxamut

East, up stream, waida, (waida)

To eat, -ama-, -ma-

Eddy, apenmaspoi

Eel (lamprey), tsāwa

Egg, anōqai, amoka*

Eight, xodaitcibum, hotaitcipum

Elder tree, tcitcxöi

Eleven, pundrāsut, saānpun punlasut

Elk, à'eno, aanok*

Empty, hutcolanan

Evening, himok*

Everything, patcimam (I)

Excrement, hi-wax

Eye, hu-sot, hu-cot*

Eyebrow, hu-sotnimi

Eyelashes, hu-sunsa

Face, hi-suma*

To fall, -man-, -mo-, -klu-

Fat (n)., pi'a
Fat (adj.), -xu-

Father, itcila-i†

Father-in-law, teu-maku

Feather, hu-to, hi-mi†

Fern, tèutèuna

To fight, -texua-

To find, -mat-

Finger, hi-ta, hi-tra, (hi-tca), hi-tcanka*

Finger-nail, bolaxot, (bulaxut)

Fir, kīpi'ina, (kimpina)

Fire, à'pu, apu*

To make fire, -cekta-, hatsir

Fire-drill, apū'ena, hâtsiktca

Fire-drill base, apū'natxui

Fire-place, akamina ā'pu

Fish-line, hook, hamamēgutca

Fish-net, atexū

Fish-trap, weir, tsāt

Fisher, qèpxamitcèi

Five, tsānehe, traněhě

To fix, -mu-

Flat, river-bench, maitra

Flea, t'amina

To float, -kim- (1)

Floor, wèboqām

Flower, atrēi

Fly, mūsaswa, mūsotri, mosotce*

'l'o fly, -tu-

Fog, āptum

To follow, -sum.

Food, hāmeu

Foot, hu-pot

Forehead, hi-mosni, $\dagger$ [hi-muclei]

To forget, -xomē-

Four, qūigu, qōigu

Fox, tcitcamŭlla, apxantcolla, haura*

Friend, [imikot], imi-mut (= love)

Frog, qâtus, (axantcibot)

Full, hitcolam

To gamble, -wemtso-

Girl, puntsŭla, puntcalla*

To give, -hak- ( $)$, awu-t*

To go, -a-, -wam-, -waum-, -wawum-, -owa-

Good, hisikni, (hisiki-), hisi-ta*

Goose, lâlo, lalo*

Gooseberry, tselina 
Gopher, yūmate

Grandfather (paternal), xāwila-i

Grandson, himolla-i

Grass, hawunna, (āwuna), koteu*

Grass-game, hēumakutca

Grasshopper, tsatur, tsatul

Grass-seed, qōmma

Green, himamto, (īmamcu), himamsu-t*

Grouse, himimiteēi

To grow, -itri-

Hair, hi-ma $\dagger$

Hand, hi-ta, hi-tra, hi-tea*

To hang, -kim.

Happy (?), teumidan

Hard, teaxi

Hawk, yěkyěk, pētcxol

Hazel, hecigo

He, hamut

Head, hi-ma†

To hear, -kē-

Heart, hu-sā'antcēi, (hu-santcei), $u$-santce*

Heavy (\&), tcumidan

Heel, inōǒkta§

Hemlock, xutexu

Here, this side of stream, kĕntcuk

To hiccup, lē-

To hide, -txat-

High, hitcūeni

To hit, -at-

To hold, -imu-

Honey, hūwūanŭkai§

Hornet, husū

Hot, elo-, (eloxni), elo-ta*

House, āwa $\uparrow$

How long, far, qâitcu

How many, qâtala

How often, qătramdun

Humming-bird, qērektce, trēlektcēi

To be hungry, -ame-, -amemtu-

Hupa, person, hitexū; place, hitewāmai

Hyampom people, maitroktada hitcuāmai

I, nōut

Ice, hatcen, atci*

Intestines, hi-pxa

Into, xunoi(?)
To jump, -tudu.

To keep, -kut-

To kick, -mitci- = with foot

To kill, -ko-

King-fisher, tsădadak

Knee, hi-txanimaxa, [hi-txanemaxa]

To kneel, -komat- (q)

Knife, tcisili, tcididi, te eselli*

To know, -trahu-

Ladder, ha 'amputni

Lake, tcitaha

Lame, hōakta-xolik

Large, trèwu-t, (djewu), tceu- $t$ *

To laugh, -yatei- $\dagger$

Leaf, hi-taxai, tahalwi*

Left-hand, xuli-teni

Leg, hi-txan, hi-tal*

To lick, -pen-, -hen-

To lie on ground, -teu

Light, tcxalĕn

Lightning, itckasĕlxun, hitckeselsel-ta*

To like, -mi'inan-

To listen, -cem-

Liver (?), hu-ci. See breast

Lizard, takteel

Lizard (red), himiniduktsa

Log, sâmu

Long, hitcun

Long ago, cul, cur, [diramda], (dilamda)

To lose, -licxu-, lülüxē-

Low, hutculan (?)

Madrone, ètxolna, [hetxolna], (hetexolna)

To make, -xai-

Man, itri, itci*

Many, much, ĕta, (hitat), itat*

Manzanita, teitcana, teitei

Manzanita-cider, tcitciaqai

Maple, trūpxadji 'ina, ipxadji'ina

To marry, -tcum-

Marten, xunēri, qāpam

To mash, -lot-

Meat (dried), pititexun

To meet, -hayaqom-

Milk, eīra, ei'ila

Mink, hunēri (?-see marten) 
Mistletoe, hâkilasaqam

Moccasin, pa, ipa $\dagger$

Mole, tsabokor, xosanmu

Moon, hìmen ălla, $\dagger$ [hīmi-n-ala]

Morning, himetasur, himetacus ${ }^{*}$

Morning-star, munoiěta

Mortar, kà'a

Mosquito, tsělēye

Moss, hikĩina

Mother, cido-i, sito-i*

Mother-in-law, teu-makosa

Mountain, awu, $\dagger$ aumiya, [āma]

Mountain-lion, tcerāsmu, [tcidasmu]

Mouse, pusudr

Mouth, ha-wa, $\dagger$ [ha-wa]

Mud, lâdido

Narrow, xē'iren

Navel, ho-napu

Nest, hemut

Nephew, micaku-i, himolla-i

Nest, hemut

New, amaninhu

Niece, himolla-i

Night, hime, himokni, [hìmi]

Nine, punteigu

No, pāteigun, (pātcikun), pateut*

To nod, -pukim-, -pupul-

Noon, himoqanan

North (west $\%$ ), xunoida

Nose, ho-xu

Nowhere, amaidātciku

Oak (black), mūne'Ena, (munena)

Oak (live, hepūitei 'ina (hepetcina)

Oak (poison), xaxecna

Oak (tan-bark), yūtxūina

Oak (white), yaqāna

Oats (wild), aqèdèu

Ocean, aquarēda, aka-tceta*

Old, xawini, hahawin-ta*

Old maid, itrīdŭsku, amālŭlla

Old man, itrincŭlla

old woman, cunhŭlla

One, pun, p'un

Onion, sāpxi

Orphan, tcisumula

Otter, ěxoitcēi, [haiokwoitce]
Outside, himinatee ( 8$)$

Owl, teukutcei, hâra

Paddle, hiāsmaigutea

" Pain,' qēhewa

To paint, -poxolxol-

To pay, -daigu-

Penis, hi-pel, [hi-bele]

Pepper-wood, watcel

Person, teimar, $\uparrow$ tcimal, [djimar], (tcimal)

Pestle, tcesundan

Pigeon, yanunūwa, yanunwa*

To pinch, -puimuk-

Pine (digger), hate'hō, hatco,ena

Pine (sugar), haqēwinda

Pine (sugar, cones), (haqeu), [haikeu]

Pine (yellow), xōsu, hosu*

Pipe, onipa $†$

Pitch, âno'a

To play, -pim-

To poke, -pat-

Poor, xodalan

Potato (wild), sāwu, qāwal, $\bar{a}$ 'asawi, sanna

To pour, -qo.

Pretty, siga

To pull, -texet-, -texa-

To push, -whek-

Quail (mountain), pisor, pisol Quail (valley), qadakin pisor Quickly, welmu welèni, luredja Quiver, hâsusakta

Rabbit (cotton-tail), hiwinolam Rabbit (jack), hēmoxola, emoholla* Raccoon, yětō'a, [yetciwa]

Rain, hìtak, itak-ta*

Rainbow, trexanmatexū

Rat, patusu

Rattle (split), hěmuimektsa

Rattle (cocoon), pātcxal

Rattlesnake, qāwu, kawu-tcane*

To recover, -nook-

Red, wili' 'i, wili-t*

Redwood, mutumana

To remember, -xutaxun-

Rich, hitam, -hada-

Right-hand, hisi-děni 


\author{
Ripe, hōmat \\ River, aqaqot \\ To roast, -maq- \\ Robin, srīto, cîtra \\ Roe, hi-txaiyi \\ To roll, -k- \\ Root, ātci \\ Rope, atcxundĕ \\ Rough, nodaduhni \\ Round, nolle \\ To rub, -xiaxe- \\ To run, -mum-
}

Salmon, ūmul, omul*

Salmon (dog), (djeida)

Salmon (hook-bill), (bitcoqolmu)

Salmon (red), masomas

Salmon (steelhead), (acotno-umul)

Salmon (summer), (umul-tcani)

Salmon (dried, crumbled), tsamma

Salmon-river people, hūnomitcku

Salmon-trout, heetsama

Salt, aqi, aki*

Sand, amayāqa

Sarvice-berry, tcimiana

Saw, hĩ-uxigutca

To say, -pa, -patci-

Scorpion (?-see cray-fish), tcisitcin, Soot, nagotpi txol

To scowl, -suta-

To scrape, -xēdo-

To scratch, -kirkir-, -xolgo-

To see, -mam-

To sell, -teiwa-

Soven, xâkuspom, qâqicpom

Shadé, qatrāta

To shake, -lucluc-

Shallow, txoděhunmi

Shaman, tcōwu, (teūu)

Sharp, cupui

Shell, ěxèu

Shell (conical), teanapa

To shiver, -nini-

To shoot, -pū-

Short, xūitculan

Shoulder, hi-ta

To sing, -tak-

Sister (older), antxasa-i

Sister-in-law, maxā-i

To sit, -tcit-, -wo-, -pat-
Six, p'untcibum, p'untepom

Skin, hi-pxadji

Skirt (woman's), hiěkteandēu (?) ōxwai

Skunk, pxicira, [pieui]

Sky, tcĕmuł

Slave, habukēdēu

To sleep, -po-

To slide, -sâp-, -sâpho-

Sling, hi-migutca

To slip, -klu-

Slowly, xowēnila

Small, ulēta

Smoke, qē

To smoke, -pa-

Smoke-hole, āpotcitpidaktca

Smooth, lūyuin

Snail, nixetai

Snake (king), mamusi

To sneeze, -ninxu-

To snore, -xâtudu

Snow, hipūi, hipue*

Snowshoes, hipui ipa, panna

Soft, lo'oren

Something, pātceamkū

Son, oělla-i, oalla-i*

Son-in-law, itcumda

Sour, qoiyŏin

South, qadaida

Spear, hâsunwedēu

Spear (fish), hohankutēu, altar

Spider, kwanpūtcikta

Spider-web, kō'okoda

To spill, -qox-

To spit, -haihu-

To split, -bis-

Spoon, wěcnaqalne, sāpxel

Spotted, lētretrē

A spring, cidŭlla, (aqa-xatsa)

Spring, kisumatci, kicumatci*

Square, hoqatā'Eni

To squeeze, -tei-

Squirrel (gray), akwēcur, [aknitcut]

Squirrel (ground), ta 'ira

To stand, -hoa-, -hâ-

Star, munu, mono*

Star (falling), munūtumni 
To stay, -wo-, -wom-

To steal, -xadj-

Stepfather, matrida

To stink, -mitexu-

Stone, qāa'a, kaa*

To stop, -txa-

Straight, hādohan

To strike, -tcut-

Striped, qisöi, ēxaduqisman

Strong, pala

Sturgeon, (umul-itcawa)

Sucker, hētcespula

Summer, ahānmatci, ahenmatci*

Sun, alla, $\dagger$ ŭlla, [asi-n-ala]

Sunflower-seed, tcintcēi

Sunrise, ěxatatkun

Sunset, hiwohunmi

To swallow, -sek-

Swallow, tumtitělla

Swamp, hixut, cita

Sweat-house, matta

Sweet, hiqūini

To swim, $-x \bar{u}-$

Table, hāma'anaksia

Tail, aqūye

To talk, -kō-, -gō-

Tattoo, hekotēu

To tear, -tra-, -xata-

Tears, hu-so'xa

Teeth, hu-tsut

Ten, sānpun

That, pāmut, pāut, pât

Thick, pepe'in

Thief, ixagutea

Thigh, hi-tcipe

Thin, tqè'erin

This, qēwot, qâat

Thou, mamut

Three, xodai, hotai

To throw, -su-, -sux-

Thumb, hi-tcitceta*

Thunder, tremūmūta, trěmamutcēu, [djememoxtcei], tcimumuta*

To tie, -wuqam-

Tinder, hauna

Tobacco, ūwu†

Today, kimāse, asseł

Tomorrow, himěda, himěta†

Tongs, isckdādiu
Tongue, hi-pen $\uparrow$

To touch, -na-

Trail, hissa

Tree, ãt'a (?), atsa*

Trout, trāwel, (tcawal) $\dagger$

Tump-line, himã'idan, kâsusū

To twist, -pxel-

Two, xoku, qâqū

Uncle (m. or p.), magola-i

Under, tcumu( ( ), wisē

Unripe, xomanat

Up, (-tso, wiemu)

Urine, e-que

Vagina, e-qā

Valley, hitexāeni (q), maiteitcam* Village, āwitat, tcimāretanama

To vomit, -haima-

To wake, -suhni-

Warrior, hētcwat

To wash, -pok.

To watch, -xota

Water, à 'ka, āqa, aka*

Water-fall, āqamatcitsxol

Water-ousel, pāsindjaxola

We, nātcidut, nōutowa, tcigule

Weak, lāpukni

Wedge, tranper

Wet, eidji'in

What, pātci, qâtci

When, qâsuk matci

Where, qōmalu, (qosi)

To whip, -nuwec-

To whistle, $-x \bar{u}$ -

White, měne'i, mene*

White-man, tcimtǔkta, (djemduakta)

Whiskey, (apu-n-aqa)

Who, qomas, komas, * awilla

Why, kosidaji

Wide, xerë'in

Widow, lasa

Widow (remarried), yapada§

Widower, mamutxū (

Wife (my), puntsar-iě, (punsal-i), puntear-hi*

Wild-cat, tagnir, tragnil, hicūmaxutcŭlla

Willow, pātc'xu 
Wind, ikosē-ta, ikosiwa*

Window, hisūsamdaksia

Wing, utū, $\dagger$ hu-tu

To wink, -raprap-, -laplap-

Winter, asōdi, asuti*

Wintun, pātcxuai

To wish, -texūū, -tcai- (q)

Wiyot( () , aqatrēduwaktada

Wiyot at Areata, qataiduwaktada

Wolf, citciwi, siteiwi*

Woman, puntsar

Wood, pusūa†

Woodpecker, konanatcēi, tcuredhu, (dedima), [dirima], (teuleti)
Wood-tick, tsina

To work, -pu-

Worm, hĕmuta

To yawn, -xaca-

Ye, qākule

Yellowhammer, tsēyamen, trīyamen, (teiaman)

Yellowjacket, xōwu

Yes, himō, $\dagger[$ [himō, hiye $)]$

Yesterday, mō'a, moo*

Young, āmanitri, amaniti-ta

\section{CHIMARIKO-ENGLISH.}

The alphabetical order is that of the letters in English. On account of of some uncertainty as regards surd and sonant stops, $b$, $d$, and $g$ have been treated as if they read $p, t$, and $k$. The same holds true of $d j$ and tc. For similar reasons $q$ has been put in the same place in the alphabet as $k$, and c as s. The sound of â apparently being nearer open o than a, these two characters have also been treated as one in alphabetizing. Ts and te may be variants of one sound; tr, in many cases at least, is not $t$ plus $r$, but a sound similar to te, with which it often alternates. These three sounds have therefore been united. Glottal eatches have been disregarded in alphabetizing. The order of the characters used is thus as follows:

$\begin{array}{ll}\text { a } & \text { p, b } \\ \text { e } & \text { r } \\ \text { h } & \text { s, c } \\ \text { i } & \text { t, d } \\ \text { k, q, g } & \text { tc, tr, ts, dj } \\ \text { l } & \text { u } \\ \text { m } & \text { w } \\ \text { n } & x \\ \text { o, â } & \text { y }\end{array}$

Words denoting parts of the body are given with the prefix of the third person. Terms of relationship usually show the suffix of the first person. Wherever the derivation or structure seemed reasonably certain it has been indicated by hyphenation.

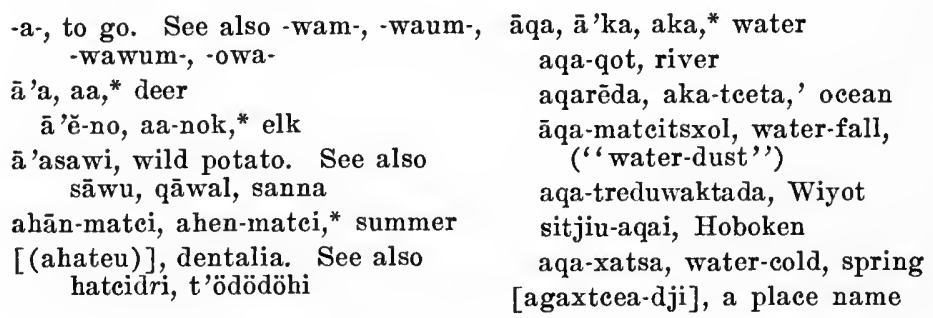


akamina â'pu, fire-place

aqĕd-ēu, wild oats

aqi,† salt

āqi-teč, [aiki-dje], Salt Ranch

aqūye, tail

akwēeur, [akuiteut], gray squirrel

alla,† ŭlla, [asi-n-ala], sun

-ama-, -ma-, to eat

hām-eu, food

-ame-mtu-, to be hungry

h-āma'a-na-ksia, table

ama, [ama], country, earth, ground mountain

ama-yāqa, sand

ama-idātciku, nowhere. Cf. patcikun, no.

ami-texamut, earthquake

[ama-tcele-dji], place name

amālūlla, old maid

amani-nhu, new

àmani-tri, amani-ti-ta, ${ }^{*}$ young

[amimamuco], place name

(amitsihe-dji), [amitsepi], village

at foot of Hupa Valley

āno'a, pitch

anōqai, amoka,* egg

antxala-i, cousin

antxa-sa-i, older sister

-ap-, to dismount, get off a horse

apenmaspoi, eddy

$\bar{a}$ 'pu, apu, * fire

apū'-ena, fire-drill. Also hâtsiktca

apū'-na-txui, fire-drill base

āpo-teitpid-aktea, smoke-hole

(apu-n-aqa), fire-water, whiskey

āptum, fog

apxante-olla, fox. Also teitcamŭlla, haura

-ar-, to climb

assĕ, $\dagger$ [asi], day, today

asōdi, asuti, * winter

asōdi-wunki, autumn

(acotno-umul), winter-salmon, steelhead

-at-, to hit

at-ar, fish-spear. Also hohankutēu

àt'a, atsa, * tree

atanisuk, sifting basket

atrèi, flower. Cf. next

àtei, root. Cf. last ateib-uksa, arrow-flaker

àteugi-djě, Bennett's, Forks of Salmon

atexū, fish-net

atcxundĕ, rope

atcxumni, dry

āwa, $\dagger$ house

awi-tat, village

-awè-, angry

awilla, who. See qömas

awu,† aumiya, mountain. Sce ama

awu-t, ${ }^{*}$ give

axac-na, chaparral. Also puktea'-Ena

axād-ēu, cats-cradle. Cf. ahateu, dentalia, which were strung

(axantcibot), frog. See qâtus

$\check{e}$, today. See also kimase

exatatkun, sunrise

elo-ta, ${ }^{*}$ (elo-xni), hot

eso-ta,* eco-, cold

ěta, (hitat), many

èt-xol-na, [hetxolna], (hetcxol-na), madrone

exatatkun, sunrise.

ĕxoi-tcēi, [haiokwoitce], otter

ha'amputni, ladder

hā'-eu, basket (acorn-mortar)

hahawin-ta, ${ }^{*}$ old

-hai-hu-, to spit

-hai-ma., to vomit

haim-uksa, ham-ukteu, ${ }^{*}$ axe

-hak-, to bring. See also -hek-hak- (q), to give

(haq-eu), [haik-eu], sugar pine cone

haq-ēw-ina, sugar pine

-ham-, to carry. See also -mai-, -qi-, -xŭ-

hamaida-dji, [amaita-dji], Hawkin's Bar

hamamë-gutca, fish-line, hook

hamut, he

haōmi-ŭksa, (haamiaktea), baskethat

habukēd-ēu, slave

-hada-, rich. Sce also hitain

hādoha-n, straight

hatcen, atci, ${ }^{*}$ ice

hate'hō, digger-pine (cone or nut)

hateo'ena, digger pine 
hatciinar-utsa, bed

hatcidri, dentalia. See also t'ödödöhi, ahateu

hātcugi-djĕ, South Fork of Trinity River

hau-na, tinder

haura, fox. See apxanteolla, tcitcamŭlla

hawēdam, [awetama], (awatamaxni), cloud

hawu-nna, (āwu-na), grass

haxa-ktca, deer-trap

-hayaqom·, to meet

heetsama, salmon-trout

-hek-, to bring. See also -hak-

hekot-èu, tatoo

hēmox-ola, emoh-olla,* jackrabbit

hĕmuime-ktsa, split-stick rattle

hemut, nest

hĕmuta, worm

hemūdadja-n, bitter

-hen-, to lick. See also -pen-

hepūitei'-ina, (hepetci-na), live oak

hecigo, hazel

-hedo-(?), to dip up

hëtcespula, sucker

bètewat, warrior

hēuma-kutca, grass-game

-hi-, to burn. See also -maa-

hiāsmai-gutca, paddle

hiěktcand-eu(?), woman's skirt. Sce also oxxwai

[hiikda-dji], a place name

hikĩ-ina, moss

hiquii-ni, sweet

himā'idan, tump-line. See also kâsusū

himamto, green; (imameu), blue; himamsu-t, , green, blue, yellow

hime, [himi], night

hīmen ălla, hime-n-alla,* hīmi-n-ala, moon

himě-da, himĕ-ta, ${ }^{*}$ tomorrow

hime-tasur, hime-tacus, ${ }^{*}$ morning

himok, * evening

himok-ni, night

himoq-anan, noon

himi-santo, (himi-samtu), "'devil," sorcerer

hīmēaqu-tce, Big Creek

himï-gutea, sling himimi-tcēi, grouse

himinıdu-ktsa, red lizard

himō,† [(himō) $]$, yes

[(hiye)], yes

himolla-i, brother's child, father's sister's child, grandson

hipūi, hipue,* snow

hīpui ipa, snowshoes. See also panna

hipuna-ktea, button

hissa, trail

[hisaa-da-mu], a place name

hisaē-mu, Weaverville

hi-ca 'amatat, belt

hisi-kni, hisi-ta,* (hisi-ki), good hisi-děni, right hand

[hisitsai-dje], a place name

hisūsamda-ksia, window

hitak, itak-ta,* rain

hitam, rich. See also -hada-

hītūtai-dji, Willow Creek

hitxaiyi, roe

hitcinemnem, dragon-fly

hitcolam, full

hutcolanan, empty

biteu-n, hiteū-eni, long, high xü-iteu-lan, short

hitcumūdad-ehu, cup and ball game

hitcxāeni ( \&), valley

hitexū, [hitchu], Hupa (person)

hitewāmai, Hupa (place)

hīŭxi-gutea, saw

hixut, swamp. See also cita

-hoa-, hâ, to stand

hōa-kta-xoli-k, lame

ho'-ěu, board

hohankut-ēu, fish spear. See also atar

hoqatā'Eni, square

hâkilasaqam, mistletoe

hōmat, ripe xomanat, unripe

hâp-ēu, acorn-soup

[(hobe-ta-dji)], Hostler village, Hupa, where an annual acorn ceremony is beld

hâra, owl. See also tcukuktcēi

hâsunwed-ēu, spear

hâsusa-kta, [(hose-ktca)], quiver hotai, xodai, three

hotai-tci-pum, xodaiteibum, eight 
hatsir, to make fire

hâtsi-ktea, fire-drill. See also apū'ena

hâtsi-na-ktea, cedar

hâdi-na-ktco-lıâda, Cedar Flat

hoxu-dji, a place name

hunoini,* Trinity river; [hunoiniwam], South Fork of the Trinity

hūnomiteku, Salmon-river people

-hus-, -xuc-, -kos-, -xu, to blow

husū, hornet

hutatat, cane

hutculan (8), low. See hiteolam, full, huteolanan, empty

[hutsutsaie-dje], a place name

huwita-dji, a place name

(ihitei), shelled acorns

imimu-t,* to love; -mi'inan, to like

[imikot], my friend

-imu-, to hold

inōŏkta, $\S$ heel

ipūit-ella, bluebird

isekdād-iu, tongs

-itri-, to grow

itri, itci, ${ }^{*} \operatorname{man}$

itri-lla, itci-la, $\dagger$ boy

itri-ne-ǔlla, old man

itrī-dŭsku, old maid

itri-xai-d-ēu, itei-haitie, * ehief

itei-la-i, itci-lla-i," father

[(iteikut)], a place name

itckasĕl-xun, hitekesel-sel-ta, * lightning

[(itcui)], a place name

iteumda, son-in-law

[itsutsatmi-dji], a place name

itexaposta, Dyer's Raneh

$-\mathrm{k} \cdot$, to roll

qā'a, kaa, stone

kā'a, mortar

$q \bar{a}-k u$, arrow-point

e-qā, vagina

[qaetxata], a place name

[kaimandot], a plaee name

qaiyausmū-dji, Forks of New River

kakesmilla,§ eivet-eat

qā'kule, ye

kalūwě,§ spoon basket qāpam, marten. See also xunēri qapu-na, deer-brush

-kat-, to break. Sce also -tcex, -xötös-

qadai-da, south

qatai-duwaktada, Wiyot at Areata qatrāta, shade

qāwal, wild potato. See also sāwu, à'asawi, sanna

qawu, kawu-teane, * rattlesnake

-kē-, to hear

hu-kē-nan, deaf

qē, smoke

-qè-, to die

që-hewa, "pain," magie cause of disease

qèpxami-tcèi, fisher

qērek-tee, humming-bird. See also trēlek tcēi

qēwot, this. See qât

kè-nteuk, here, this side of stream

bi-ki,ł neck

-qi-, to earry. See also -mai-, -ham-, -xŭ-

-kim-, to hang, to float (?)

kimāse, today. See also è

kipi'-ina, [kimpi-na], fir

-kir-, to scrateh. See also -xolgo-

qis-öi, exadu-qis-mam, striped

kisum, erane. See also kâsar

kisu-matei, kicu-matci, * spring

-klu-, to slip; also to fall, for which see also - man, -mo-

-kma-, to eomb

-ko-, to kill

-kō-, -gō-, -kokō-, to talk, to eall

[kokomātxami], a place name

-kos-, -xue-, -hus-, -xu, to blow

i-kos-èta, i-kos-iwa, * wind

-qo-, to pour

-qox-, to spill

qoido, dew

qō-mas, $\uparrow$ who. Seo also awilla qâ-tei, what. See also pã-tei qō-malu, (qo-si), where

qâ-iteu, how long, how far

ko-sidaji, why

qâ-sukmatci, when

qâ-tala, how many

qă-tramdun, how often 
qō'a, beetle

kō'okoda, spider-web

qâqū, xoku, two

qōigu, qūigu, four

qâqic-pom, xâkus-pom, seven

-komat-( () , to kneel

qōmma, grass-seed

qo'ōměniwiuda, New River City

konona-tcēi, woodpecker. See

also teuredhu

-koru-, to bend

kâs-ar, kisum, crane

kâsusū, tump-line. See also himā'idan

qât, qēwot, this

kâteu, clover; koteu," "grass",

qâtus, frog

kōwa, coals

qoiyŏ-in, sour

kumitc-in,* all

e-que, urine

-kut-, to keep

-kut-, to cut. See also -lolo-

kwanpūteikta, spider

-kxol-, to dent. See also -tran-

-laplap, raprap-, to wink

lasa, widow

lāpuk-ni, weak

lē-, to hiccup

lētretrē, spotted

-lolo-, to cut. See also -kut-

lâlo, lalo,* goose

-lot-, to mash

lo or-en, soft

lâd-ido, mud

lū-, lui-t, ${ }^{*}$ to drink

-lul-, -lurim-, -lus-, to drop

luredja, quickly. See also welmu

-lucluc-, to shake

lüyu-in, smooth

hi-ma,† hear, hair. Cf. himāidan ma-mut, thou

-maa-, to burn. Se also -hi-

-maq-, to roast

-mai-, to carry. See also -ham-, -qi-, -xŭ-

hi-māidan, tump-line

maitra, flat, river-bench

maitcitcam, ${ }^{*}$ valley maidja-hūtcula, Yocumville

maidpa-sōre, Thomas', a place

maidja-teū-djĕ, Cecilville

maido-lēda, Jordan's

maito-töu-dji, Summerville

maitro-ktada, Hyampom people

(maidjandela), [maidjandera],

tcitindosa, coyote

-maka-, to dream

mago-la-i, (my uncle, maternal or paternal

teu-maku, father-in-law

teu-mako-sa, mother-in-law

maxã-i, sister-in-law

mālai'-i, (my) aunt, (maternal)

-mam-, to see

-mat-, to find

-mamat-, alive

mamsūidji, a place

mamusi, king-snake

mamutxū (q), widower

-man-, to fall. See also -mo-, -klu-

masola-i, maisola-i, daughter

masomas, red salmon

mata'-i, clean

matta, sweat-house

matrepa, matcitsxol, dust

matripxa, ashes

matrida, step-father

matciya, acorn-soaking place

mèku-i, brother-in-law

mēne'-i, mene, * white

men-drahĕ, disk beads

hi-mi, $\dagger$ feather. See also hu-tu

hi-mina, back

hi-mina-tce, behind, outside

micaku-i, nephew

-mitci-, to kick, with foot

-mitexu-, to stink

-mo-, to fall. See also -man-, -klu-

mõ'a, moo,* yesterday

hi-mosni, hi-musni,* [hi-muclei], forehead

-mu-, to fix

-mum-, to run

[(muni)], black-oak acorn

mūne'-Ena, (mune-na), black oak

munu, mono,* star

muno-iěta, morning-star

munū-tumni, falling star 
mūsaswa, musotri, mosotce, ${ }^{*}$ fly mūtala-i, maternal aunt

mūtumma, motuma," canoe mutuma-na, redwood

[(mutuma-dji)], Captain John's village at Hupa, which is reached only by boat

-na-, to touch

nagotpi, soot

ho-napu, navel

nātcidut, we. See also noutowa, tcigule

[(neradji)], village at head of Hupa valley

hi-ni, brain

-nini-, to shiver

-ninxu-, to sneeze

nixětai,§ snail

nolle, round

hi-wi-nollom, rabbit (cotton-tail)

no-matei,* autumn

-nook-, to recover

nodaduh-ni, rough

nōut, I

nōutowa, we. See also natcidut, teigule

-nuwee, to whip

o-člla-i, o-alla-i, * my son

ōèl-ŭlla, bachelor. See also puntsariěcku

onīpa, $\uparrow$ pipe. Cf. -pa-, to smoke

(opuma-ktca), storage basket

-owa, to go

-owa-tok, to come

ōxwai, woman's skirt. See also hiětcandeu

-pa-, to smoke. Cf. onipa, pipe

-pa-, to say

pa, ipa, $\uparrow$ moccasin

pa-nna, snowshoes. See also hīpui ipa

paktō'-ena, alder

paktōna-dji, baktuna-dji,

Patterson's

pala, strong

pāmut, pāut, pât, that

pāci, leached acorn-meal

pāsindjax-ola, water-ousel

-pat-, to poke

-pat-, to sit. See also -tcit-, -wo- pātci, what. See also qâtei pātce-amkū, something pātci-gun, (pātci-kun), no patci-mam ( $($ ), everything pateut, ${ }^{*}$ no

pātexal, cocoon rattle pāte'xu, willow patexūai, Wintun patusu, rat pāut, pāmut, pât, that hi-pel, [hi-bele], penis pèlo'a, black ant -pen-, -hen-, to lick hi-pen, $\dagger$ tongue pepe'-in, thick pētexol, hawk. See also yěkyěk pì'a, fat (noun) -pim-, to play pip-ila, chipmunk. See also wisilla -bis-, to split pis-or, pis-ol, quail pititcxun, dried meat (bitcoqolmu), hook-bill salmon p'qělě'-in, crooked

hu-po, $\uparrow$ foot

hu-po-ckun, footless

-po-, to dig. See also -tsik-

-po-, to sleep

-pok-, to wash

poq-ela, cooking basket

pola, alone

bolaxot, (bulaxut), finger-nail

pât, pamut, pāut, that

pâdju, [poteu], grizzly bear -potpot-, to boil. Se also -dum. powa, open-work tray basket -poxolxol-, to paint -pu-, to work -pū-, to shoot -puimuk-, to pinch punuslala, by and by -pukim-, -pupul, to nod puktca'-Ena, chaparral. See also axacna

pun, p'un, one p'un-tcibum, p'untepom, six pun-tcigu, nine pun-drāsut, eleven. See also saānpun punlasut

p'unna, tray basket 


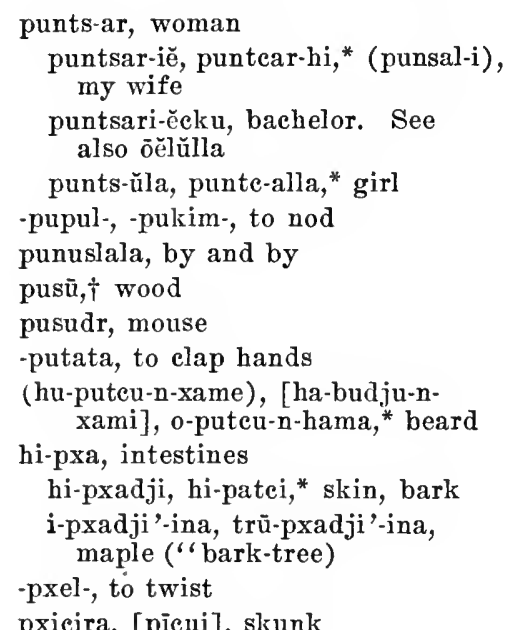

pxicira, [pieui], skunk

sa'a, arrow

hi-sam, hi-cam, ${ }^{*}$ ear -cem-, to listen

-samxu-, to dance

hi-samqu-ni, drum

sanna, wild potato. See also sāwu, qāwal, à 'asawi

sangen, (cānkeen), burden basket

sānpun, ten

saānpun punlasut, eleven. See also pundrāsut

hu-sa'antcēi, (hu-santcei), u-santce, ${ }^{*}$ heart

sāpxel, spoon. See also wěc-naqalne sāpxi, onion

sāwu, wild potato. See also qāwal, à'asawi, sanna

-sax-, to cough

-saxutxut, to breathe

-sek-, to swallow

-cekta-, to make fire. See also hatsir

hu-ci, liver; (husi), u-si, * breast

-sik-, to drive

siga, pretty

cìra, ci 'illa, sī'lēye, sirha,ị [cīda], woman's breast, milk

cilēi-tcūmuni, arm-pit

[eiloki], a place

-sim-, accompany

teu-simda, daughter-in-law

cibui, awl

eita, swamp. See also hixut citimāā-dji, Big Bar

cido'-i, sito-i,* (my) mother

citra, srīto, robin

citrqi, sötri, sitsö,* blood

södrè-, to bleed

citc-ella, site-ela, $\dagger$ dog

citc-iwi, site-iwi, wolf

cidji'-in, wet

sitjiwāqai, Hoboken

cid-ŭlla, a spring

sâmu, log

-sâp-, sâpho, to slide

hu-sot, hu-cot, ${ }^{*}$ eye

hu-sot-nimi, eyebrow

hu-sunsa, eyelashes

hu-so'-xa, tears

sötě'i, blue (q-cf. blood)

-su-, -sux-, to throw

-suhni-, to wake

eul-, cur, long ago

sulhim, abalone

-sum-, to follow

hi-suma,* face

hi-cum-axutculla, wild-cat

cun-hŭlla, old woman

cupui, sharp

-suta-, to scowl

[suta-dji], a place

-sux-, -su-, to throw

-dah-, born

-daigu-, to pay

ta'ira, ground squirrel

-tak, to sing

tagnir, trcagnil, wild-cat

taktcel, lizard

t'amina, flea

tamini, by and by

t'amitexul, red ant

hu-tananundjatun, cheek

tanatci, comb

hi-taxai, tahalwi,* leaf

(tabum), again

(dedima), [dirima], woodpecker. See also konanantcēi, tcuredhu, teuleti

tèutèu-na, fern

tirha,* (di'la), bird

tira-cela, tēila-tcele, blackbird

dilamda, [diramda], long ago

tqĕ'er-in, thin 
tono'-i, dull

-tot-, to bury

t'ödödöhi, hatcidri, dentalia. See also ahateu

-tu-, to fly

hu-tu, u-tū, $\dagger$ feather, wing.

See also hi-mi

-tudu-, to jump

-dum-, to boil. See also -potpot-

tumtit-ělla, swallow

t'ummi, armor. See also teitxa

-txa-, to stop

hi-txan, hi-tal,* leg

hi-txanimaxa, [hi-txanemaxa], knee

hi-txan-lède, hi-kxan-lède, ạkle

-txat-, to hide

-txax-, abandon. Cf. -taxt-

txol, trxol, scorpion ( 9 ), crayfish. See also teisitcin

txoděhunmi, shallow

hu-txun, bone

hi-tra, hi-ta, (hi-tea),* hand, finger, arm, shoulder

traněhě, tsānehe, five

hi-teanka, ${ }^{*}$ fingers

hi-tanpu, [hi-tcanpu], hi-teanpo,* arm

hi-tci-tceta, thumb

-tra-, to tear. See also -xara-

-trahu-, to know

-tcai-( ( ), -tcxūū-, to wash

treagnil, tagnir, wild-cat

tsamila, butterfly

tsāmma, dried crumbled salmon

-tran-, to dent. See also -kxol-

tcanapa, conical shell

tranmi-da, downwards

tranqōma, Hyampom

tranper, wedge

tsabok-or, mole

tsāt, fish-trap, weir

tsādadak, king-fisher

tsat-ur, grasshopper

-tcatci-, to chew

tsāwa, lamprey eel

trāwel, [teawal], , trout

(djāwidjau), eagle. See also wemer teaxi, hard

(djeida), dog-salmon -tcex-, to break. See also -kat-, -xötös-

tcĕlē-i, tceli-t,* black

tcelē'-in, dirty

trēlektcēi, qērektce, humming-bird

tsēlēye, mosquito

tseli-na, gooseberry

$[($ tcem-da $)]$, across stream

tcĕmu, $\dagger$ sky

-tcemux-, to clear (weather)

tremū-muta, trěma-mute-ēu, tcimu-muta, thunder

tcem-xatc-ila, bat

tcĕn-eu, acorn-bread

tcerāsmu, [tcidasmu], mountain-lion tcesundan, pestle

tcètcèi, buzzard

trèwut, tceu-t,* (djewu), large

trexanmatexū, rainbow

-tei-, to squeeze

tcim-ar, teim-al, (tcim-al),

[djim-ar], person, Indian (teim-al-iko), Chimariko

tcimār-etanama, $\uparrow$ village

tcim-tūkta, (djem-duakta), white$\operatorname{man}$

tcimia-na, sarvice-berry

tsina, wood-tick

-tsik-, to dig. See also -po-

teigule, we. See also natcidut, noutowa

teintxap-mu, [djundxap-mu], Big Flat

hi-teipe, thigh

tcirhuntol, buekskin

teisamra, teisamrha, ${ }^{*}$ (djicamla), [djisamara], black bear

tcisili, tceselli, ${ }^{*}$ tcididi, knife

tcisitcin, scorpion. See also txol, trxol

tcisum-ula, orphan

-teit-, to sit. See also -wo-, -pat-

teitaba, teitaha,* lake

teitra, Trinity River

teitindōsa, coyote. Cf. tciteam-ulla, fox

teitxa, armor. See also t'ummi

-tciwa-, to sell

teitcam-ŭlla, fox. See also apxantcolla, haura. Cf. tcitindōsa, coyote 
teitea-na, manzanita teitcan-ma, [djitcaan-ma], Taylor Flat

tcitci-āqai, manzanita-cider teitexöi, elder tree

trīyamen, tsēyamen, (tciaman), yellowhammer

(tso), up. See also wiemv

tsokokotce, bluejay

teolidasum, [djalintasun, djalitasom] New River

teōwu, (teũu), shaman

hu-tsu, u-tsu, ${ }^{*}$ teeth

-teuk-(\%), to drown

tcukutcëi, owl. See also hâra

-teum-, to marry

tcumidan, happy (?), heavy (?)

tcumu (q), under

tsuna, chin. See also hu-wetu

tsuna-na, digging-stick

hu-trun-èu, (hu-tcen-eu), u-tcuniwa, belly

trūpxadji'-ina, ipxadji '-ina, maple

teuredhu, (tculeti), woodpecker. See also konananteèi, dedima, dirima

-tcut-, to strike

tsūdamda-dji, [djidamada-dji], Burnt Ranch

teuxunmin (?), deep

-texa-, -tcxet-, to pull. See also -texet-

texal-ĕn, light

-texet-, texa, to pull

trxol, txol, cray-fish, scorpion (?)

-texua-, to fight

(texupun), acorn. See also yutri

-texūū, -tcai-, to wish

ulēta, small

ulūida-i, (my) paternal aunt

ũmul, omul,* salmon

(umul-itcawa), sturgeon ("largesalmon")

(umul-teani), summer salmon ūwu, $\dagger$ tobacco

ha-wa, $\dagger$ mouth

wai-da, east; (wai-da), up-stream -wak, -watok-, to come

wa 'la, wa'da, crow

-wam-, -waum-, -wawum-, -a-, to go

-watok-, -wak, to come watcel, pepper-wood

hi-wax, excrement

welmu, quickly. See also luredja wemer, eagle. See also djāwidjau -wemtso-, to gamble

wenteu, cradle

wèboqām, floor

ho-wec, antlers, horn

wěc-naqalne, spoon

wěssa, door

hu-wětu, chin. See also tsuna

-whek-, to push

hi-wi, anus

(wiemu), up. See also tso

wili 'î, wili-t,* red

wisè-da, down-stream

wisilla, chipmunk ( \&), beaver ( ( ). See also pipila

-wo-, to cry

-wo-, -wom, to sit, to stay. See also -tcit-, -pat-

hi-woanad-atsa, chair

hī-wo-hunmi, sunset

wowoin, to bark

-wuqam-, to tie

-xai-, to make

xamoa-na, blackberry

xar-ŭlla, hal-alla,* (xal-ala), baby

-xaca-, to yawn

-xata-, to tear. See also -tra-

-xadj-, to steal

i-xa-gutca, thief

(xatsa), cold

(xaumta-dji), a village in Hupa, below the Ferry

[xawaamai], Mad River

xaxa-tcèi, duck; hahatce, ${ }^{*}$ mallard duck

xaxec-na, poison oak

xawin, caterpillar

xawi-ni, old

xēe'ir-en, xerē'-in, narrow (\&), wide (?)

-xēdo-, to scrape

-xiaxe-, to rub

xoku, qâqū, two

xâku-spom, qâqi-cpom, seven

-xolgo-, to scratch. See also -kirkir-

-xomē-, to forget

xâpun-ěu, bow 
[xoraxdu], a place

xỏsu, hosu,* yellow pine

xodai, hotai, three

xodai-tcibum, hotai-tcipum, eight

xodalan, poor. Cf. -hada-, rich

-xötös-, to break. See also -kat-, -tcex-

-xâtudu, to snore

xowēn-ila, slowly

xōwu, yellow-jacket

-xu-, -xuc-, -hus-, -kos-, to blow

$-x u \overline{-}$, to whistle

$-x \bar{u}-$, to swim

-xŭ-, to carry. See also -mai, -ham-, -qi-

ho-xu, nose

$-x u-$, fat (adj.)

-xuc-, -xu-, -hus-, -kos-, to blow

xūiteu-lan, short

xuli, holi-ta, ${ }^{*}$ bad

xuli-teni, left-hand xunēri, hunēri, marten( ()$, \operatorname{mink}(?)$.

See also qāpam

xunoi-da, west ( 9 ), north ( 9 )

-xutaxun-, to remember

xutexu, hemlock

(xuwetei), deer (buck). Cf.-wec, antlers

yaqā-na, white oak

[yaqana-dji], a place

yanunūwa, yanunwa, ${ }^{*}$ pigeon

-yatci-, iatci-mut,* to laugh

yěkyěk, hawk. See also pētcxol

yětō'a, [yeteiwa], raccoon

(yetcawe), deer (doe)

yōma, unleached acorn-meal

yonot, buckeye

yümatc, gopher

yūtri, acorn

yūtxūi-na, tan-bark oak

yūura, dove

\section{PLACE NAMES.}

Taylor Flat

Cedar Flat

Burnt Ranch

Hawkin's Bar

Dyer's ranch

Patterson's

Thomas'

Forks of New River

New River City

Willow Creek

Big Bar

Weaverville

New River

Big Creek

Trinity River

Hoboken

South Fork Trinity River

Summerville

Jordan's

Cecilville

Yocumville

Bennett's

Hyampom

Big Flat

Salt Ranch

Mad River tcittcanma [djitcanma]

hâdinaktcohâda

tsūdamdadji [djidāmadadji]

hamaidadji [amaitadji]

itcxaposta

paktōnadji [baktunadji]

maidjasōre

qaiyausmūdji

qo'ōmĕniwinda

hìtūtaidji

citimāādji

hisaēmu

tcolidasum [djalintasun, djalitasom]

hīmēaqutce

teitra

sitjiwāqai

hātcugidjè

maitotöudji

maidolēda

maidjatcūdjĕ

maidjahūteula

ātcugidjĕ

tranqōma

tcintxapmu [djundxapmu]

āqitcě [aikidje]

[xawaamai] 
Hupa, village at foot of valley

Hupa, village below Ferry

(amitsihedji) [amitsepi]

Hupa, Hostler village

[hobetadji]

Hupa, Captain John's village

(xaumtadji)

Hupa, village at head of valley [(neradji)]

Unidentified place names mentioned by Doctor Tom to Dr. A. L. Kroeber: amimamuco, hikdadji, kaimandot, itcikut, itcui, hoxudji, sutadji, hisitsaidje, huwitadji, qaetxata, yaqanadji, amatceledji, itsutsatmidji, agaxtceadji, baktunadji ,hisaadamu, xoraxdu, hutsutsaiedje, ciloki, kokomatxami. 


\section{INDEX.*}

Abalone, 298.

Achomawi, 241, 260.

Acorns, 299.

Accidental possession, 320, 323 .

Adjectives, 334 .

Adolescent girl, 109.

Adzes, 300.

Affixes, 317.

Affricatives in Hupa, 16.

Altsodoniglehi, 61 .

American Anthropologist, 73, 253, 296.

American Folk-Lore Society, 26.

American Indians, 24.

American languages, 1, 19, 70.

Apron, 298.

Arabic, 23.

Arizona, 25.

Armor, 300.

Arrowheads, 253.

Arrows, 246, 247, 259, 282, 300.

Arrow-straightener, 253, 284.

Athapascan, 67, 68, 71, 74, 80, 131, 296; Athapascan dialects, 7, 9, $11,13,17$.

Atsugewi, 337.

Bale's lake, 242.

Baskets, 250, 253, 264, 268, 270, $272,274,278,300$.

Békotsìdi, 58, 59 .

Belt, 258, 276.

Bennet's, 379.

Bevier, 3.

Bezinyasin, 32, 33.

Big Bar, 296, 297, 379.

Big creek, 379.

Big Flat, 379.

Bill Ray, 68, 201.

Black Hills, 241 .

Blanket, 255.

Blue Rock, 67, 217.

Blue Rock creek, 233.

Bly, 241.

Bodily decoration, 298.

Bows, 246, 282, 300.

Breech-clout, 298.

Bureau of Ethnology, 240.

Burnt Ranch, 297, 379.

Cahto, 226.

California, Ethnological and Archaeological Survey of, 239.
Camass, 243, 256.

Cannel coal, 26.

Canoe, 243, 247, 248, 259, 260, 262, 300 .

Cape, 255.

Caps, 255, 276, 293.

Case, grammatical, 321, 323.

Cats-cradle, 302.

Cedar Flat, 297.

CeLcīyetōdû̃u, 191, 208, 214.

Central California, 260, 305, 311, $321,335,336$.

Ceremonials, 303.

Cecilville, 379.

Charms, 253.

Chelly Cañon, 25.

Chesnut, V. K., 149.

Chief, 301.

Childbirth, 302.

Chimalakwe, 296.

China Flat, 307.

Chumash, 320.

Classification of sounds, 4 .

Clear lake, 241.

Coast Range, 246.

Collective, 323 .

Columbia, 259.

Comb, 286.

Composition, 311.

Connectives, 335 .

Continuants in Hupa, 8.

Contributions to North American Ethnology, 11, 67.

Corral creek, 296.

Coville, 243, 247, 249, 254, 255, 256.

Cox's Bar, 296.

Coyote, 68, 191, 195, 211, 217, 218, $219,222,231,232,304$.

Cradle, 257, 270.

Crater lake, 240.

Creation, 304.

Cremation, 302.

Culin, Stewart, 253.

Cup and ball game, 302 .

Dairy, 242.

Dakota, 23.

Dawn Boy, 26, 27, 28, 31, 33, 34.

Deformation of head, 257.

Demonstratives, 322 .

Dentalia, 298.

* Univ. Calif. Publ. Am. Arch. Ethn., Vol. 5. 
Index.

Depéntsa, 32.

Derivation, 311.

Deschutes river, 240.

Dialects, Eel river, 135.

Dip-net, 243, 249, 259, 262.

Directional suffixes, 319,330 .

Dixon, R. B., 296, 299, 302, 337 ; and Kroeber, 336.

Dog, 304.

Dorsey, George A., 253.

Dreams, 303.

Dress, 298.

Dual, 322.

Dutch Henry creek, 226.

Dyer, Mrs., 295, 307, 309, 363.

Dyer's, 297, 379.

Dzicdanistíni, 26.

Earth lodge, 243.

Eel river, 67, 201, 224, 226, 234.

Eels, 298.

Elk, dancing, 227.

English, 2, 8, 10, 11, 12, 13, 14, 22, 23.

Esselen, 295.

Estsánatlehi, 47, 59.

Ethnological and Archaeological Survey of California, 239.

Evernia vulpina, 254.

Exploded sounds, 19, 70.

False palate, 3 .

Fire drill, 257.

Fire, securing of, 304 .

Fire, theft of, 349 .

Fish-hooks, 250, 259, 286.

Fish spear, 247, 251, 259, 300.

Fish trap, 257, 280.

Flood, 304, 341 .

Flute, 300.

Food songs, 32 .

Fourier's theorem, 3 .

French, 13, 23.

French creek, 296.

Friday, 295, 307, 309, 363.

Funerals, 302.

Games, 253.

Gambling, 302.

Gambling tray, 264.

Gatschet, A. S., 241, 246.

Geese, 224.

German, 2, 12, 13, 23, 70 .

Goddard, P. E., 296, 299, 307, 363.

Gopher, 223.

Grass-game, 302.

Grasshoppers, 299.

Grasshopper Girl, 30, 47, 48.

Hair brush, 258.

Haliotis, 26, 31, 32, 59.

Harpoon, 251, 286.

Hastséhogan, 27, 28, 29, 30, 33.

Hastséyalti, 26, 27, 28, 29, 33, 34.
Hatali Natloi, 24, 59.

Hats, 278.

Hawkin's Bar, 297, 379.

Hay Fork of Trinity river, 296.

Hayolkál Aski, 26, 28.

Headbands, 257.

Hearst, Mrs. Phoebe A., 239, 295.

Hermann, 3 .

Hoboken, 379 .

Horse, 35.

Horse Fly valley, 242.

Hostler village, 380 .

Houses, 243, 299.

House God, 27, 29, 47, 48 .

Hupa, 68, 71, and foll., 295, 296, $297,298,299,300,301,303,304$, $305,306,336,354,361,363,380$.

Hupa language, 4.

Hupa Texts, 10, 17.

Hyampom, 296, 379.

Imperative, 329.

Incorporation, 321 ; nominal, 328.

Independent pronoun, 322.

Infixes, 320 .

Inherent possession, 320, 323 .

Instrumental prefixes, 318, 329.

Intensive suffix, 321, 322 .

Interrogatives, 322.

John Wilson creek, 231.

Jordan's, 379.

Juniper, 257, 274.

Julius Marshall, 4.

Kai Pomo, 67.

Kangaroo-rat, 217.

Karok, 303.

Kato, 67, 68.

Keen creek, 240.

Kelta, 11.

Keno Spring, 242.

Kethawn, 27.

Kibesillah, 191, 205.

Kininaekai, 25, 29.

Klamath Falls, 241.

Klamath Indian Reservation, 239.

Klamath lakes, 240, 241, 242.

Klamath Lake Indians, 239.

Klamath marsh, 240, 241, 242.

Klamath river, 240 .

Konomihu, 305, 337.

Kroeber, A. L., 307, 309, 354, 363, 380.

Kymograph, 2, 3.

Laytonville, 67, 197.

Leggings, 255, 276.

Leldiñ, 11.

Levirate, 301.

Lightning of the Thunder, 61 .

Link river, 241.

Linkville, 241.

Lip positions, photographs of, 2 . 


\section{Index.}

Little Lake valley, 198, 226 .

Locative suffixes, $319,321,323$.

Lockey Flat, 242.

Lōdaikī, 226.

Long valley, 67, 198.

Long Valley creek, 225.

Lost river, 241.

Lost River valley, 242.

Lutuami, 239, 240, 241, 242, 253, $258,259$.

Mad river, $219,379$.

Maidu, 299, 311, 320, 321, 329.

Marey tambor, 4.

Marriage, 301.

Marshall, Julius, 4.

Mats, 245, 260, 264, 288, 290, 292.

Matthews, Dr. Washington, 24.

Maul, 252, 259, 284.

Meadowlark, 224.

Mechanical Aids to the Study and Recording of Language, 3.

Mendocino county, 67.

Mesh-measure, 286.

Mesh-stick, 250.

Milkweed, 250.

Moccasins, 255, 276, 280, 298.

Modal-temporal affixes, 319, 321, 331.

Modoc, 240, 241.

Modoc Indians, 239.

Monosyllabic stems, 333 .

Months, 205.

Morphology of the Hupa Lan. guage, 12, 18.

Mortar, 252, 284

Mud Springs, 198.

Muller, two-horned, 252, 259, 266, 284.

Mythology, 304.

Nagaitcho, 68, 183, 185, 186.

Nasals in Hupa, 9.

Navaho, 12, 77; Navaho Legends, $26,27,28$.

Negative, 332 .

Net sinker, 259, 284 .

Nets, 247, 249, 250, 252, 300.

Nettle, 250, 288.

New river, $295,296,307,379$; city, 296,379 ; forks of, 379 ; tribe, 305.

Night Chant, 24, 25, 26, 27, 28, 35, 54

$\mathrm{Ni}^{\prime}$ nahoká dine', 27.

Noble, Mrs., 363.

Nongatl, 149, 219.

Northwestern California, 259, 260, $300,304,305,311,335,336$.

Number, 321, 323.

Numerals, 334.

Nymphia polysepala, 242.

Object, nominal, 327 ; pronominal, $326,327$.
Offspring of the Water, 61 .

Oklahoma, 240.

Olene, 242.

Onomatopoeia, 311.

Order of words, 335

Oregon, 239, 259, 301, 306.

Origin of earth, 183; of fire, 195 ; of fresh water, 188; of light, 191,195 ; of secds, 210 ; of valleys, 197 .

Paddle, 248.

Palate, false, 3.

Palatograms, 2 .

Patterson's, 297, 379.

Pains, in Chimariko, ceremonial, 303.

Paiute, 259.

Pelado Peak, 47.

People on the earth, 27.

Pestle, 252, 284.

Phonograph, 3 .

Pine-nuts, 299.

Pipes, 253, 259, 286, 300.

Pit river, 241.

Place names, 379.

Plains Indians, 259.

Plants used by the Indians of Mendocino Co., Calif., 149.

Platters, 256, 268.

Plural for politeness, 143.

Pollen Boy, 30, 47, 48.

Pomo, 67.

Polysyllabic stems, 334.

Porcupine, 254.

Possession, 320, 323.

Postpositions, 335.

Pouch, 270.

Powers, S., 67, 296, 307, 362.

Prefixes, 318, 320.

Pronominal affixes, 318, 324.

Puberty ceremonials, 301.

Putnam, F. W., 24.

Quiver, 255, 282, 300.

Quoits, 302.

Rafts, 255, 260.

Rancheria Flat, 198.

Rattles, 300.

Rattlesnake as husband, 234.

Ray, Bill, 68, 201.

Reclining Mountain, 26.

Redemeyer's ranch, 197, 235.

Red Mountain, 217.

Red Rock House, 25, 30, 31 .

Reduplication, 311, 334.

Redwood creek, 227.

Reflexive, 328.

Rhett lake, 240, 241, 242, 243.

Rock crcek, 198.

Rocky Mountain sheep, 35 .

Rogue river, 240.

Round-dance, 303. 
Index.

Round Valley, 198.

Rousselot, kymograph, 2, 3, 4, 10.

Sacks, 256.

Sacramento Valley, 299.

Saisûntcbī, 233.

Sak 'enûnsandû̃̃, 225.

Salmon, 298.

Salmon river, 297.

Salt Ranch, 379.

San Francisco mountain, 49.

San Juan mountains, 49.

San Mateo mountain, 49.

Sapir, Edward, 68.

Scirpus lacustris, 244, 290.

Scirpus robustus, 244, 288.

Scott Valley, 297.

Scratching-stick, 301.

Scripture, E. W., 3.

Seed-beater, 257.

Semi-rowels in Hupa, 8.

Sentences, 361.

Serpent, horned, 226.

Shaman, 60, 303.

Shasta, 295, 296, 297, 303, 305, $306,307,311,320,321,327,329$, $335,336,337,339$.

Shasta-Achomawi, 296.

Sheep, 35.

Sherwood valley, 226.

Shoshonean, 258.

Shuttle, 250, 286.

Sierra Nevada, 246.

Slayer of the Alien Gods, 61.

Snake-skin, 298.

Snow-shoe, 255, 276, 298.

Sound-representation, 2.

Sounds in Kato, key to, 69.

Spanisl, 67, 70 .

Spear points, 253.

Spirants in Hupa, 10.

Spoon, 268, 300.

Spoon-shaped basket, 255.

Sprague river. $241,242$.

Stems, monosyllabic, 333; polysyllabic, 334 .

Stops in Hupa, 13.

String, 250; nettle string, 288.

Suffixes, 319, 320, 321, 323.

Summer house, 244, 264.

Summerville, 379.

Sun Bearer, 58.

Sun shelter, 245.

Sweat-dance, 303.

Sweathouse, 245, 246, 299.

Sycan marsh, 241; river, 242.

Syringa, 300 .

Taboo, 109, 199, 205.

Talking God, 27, 29, 47.

Tambor, 4.

Tattooing, 298.
Taylor's Flat, 296, 297, 379.

TcûLsaitcdûñ, 221.

Ten-mile creek, 221, 233.

Thomas', 297, 379 .

Thunder, 68, 185, 186.

Tolowa, 8.

Tom, Dr., 295, 309, 354, 363, 380.

Torch, 257, 286.

Trays, 256.

Trinity county, 295, 307.

Trinity river, $297,306,379$; south fork of, $295,297,379$.

Trunks, 300 .

Tse' gílhe, 28, 32, 33, 54 .

T'sétintyel, 28.

Tsénitsihogan Bigǐ'n, 25.

Tse' yahódilyǐl, 28.

Tsínihanoai, 58.

Tule, 244, 253, 254, 256, 258, 264, $268,270,272,278,280,288,290$.

Tule lake, 240, 241, 242, 243.

Turtle, 222, 223.

Turquoise, 26, 59.

University of California, 239; Department of Anthropology of the, 24, 295.

Verb stems, 332.

Vocabulary, 362.

Vowels, 307 ; in Hupa, 5.

Washington, 301.

Washo, 320, 321.

Water-panther, 235.

Wailaki, 67, 68, 201, 234.

Weaverville, 379

Wedges, 252.

White Corn Boy, 30.

White House, 25, 26, 27, 28, 29, 31, 34.

Widows, 302

Willow, 256, 278.

Willow creek, 307,379 .

Wintun, 295, 296, 298, 305, 306, $311,321,329,336,337$.

Wiyot, 304 .

Wokas, 243, 248, 252, 255, 256, $259,266,268,274,280$.

World behind the ocean, 209 .

Worms, 299.

Yainax, 242

Yam Say peak, 241.

Yana, 295, 311, 337.

Yatcû́saik'wût, 193.

Yelindun, 193

Yellow Corn Girl, 30.

Yellow-hammer, 205, 207, 209.

Yellowjackets, 299.

Yocumville, 379.

Yuki, 67, 191, 226, 231.

Yuni, 31.

Yurok, 303. 
UNIVERSITY OF CALIFORNIA PUBLICATIONS - (CONTINUED)

Vol. 8. 1. A Mission Record of the Callfornia Indians, from a Manuscript in the Bancroft Library, by A. I. Kroeber. Pp. 1-27. May, 1908

2. The Ithnography of the Cahuilla Indians, by A. I. Kroeber. Pp. 29 . 68, plates 1-15. July, 1908

3. The Religion of the Iuisex̃o and Dieguexo Indians of Southern Cali. fornia, by Constance Goddard Dubols. Pp. 69-186, plates 16-19. June, 1908

4. The Culture of the Iuiseño Indians, by Philip Stedman Sparkman. Pp. 187-234, plate 20. August, 1908

5. Notes on Shoshonean Dialects of Southern California, by A. I. Kroober. Pp. 235-269. September, 1909

6. The Beligious Practices of the Diegueño Indians, by T. T. Waterman. Pp. 271-358, plates 21-28. March, 1910

Vol. 9. 1. Yana Texts, by Edward Sapir, together with Yana Myths collected by Roland B. Dixon. Pp. 1-235. February, 1910.

Volumes now completed:

Volume 1. 1903-1904. 378 pages and 30 plates

Volume 2. 1904-1907. 393 pages and 21 plates

Volume 3. 1905. The Morphology of the Hupa Language. 344 pages

Volume 4. 1906-1907. 374 pages, with 5 tables, 10 plates, and map

Volumo 6. 1908. 400 pages, with 3 maps

Volume 7. 1907-1910. 441 pages and 50 plates

GRAECO-ROMAN ARCHAEOLOGY. (Large Octavo.) (Published by the Oxford University Press.)

Vol. 1. The Tebtunis Papyri, Part 1. 1902. Edited by Bernard P. Grenfell, Arthur S. Hunt, and J. Gilbart Smyly. $x i x+674$ pages, with 9 plates. Price

Vol. 2. The Tebtunis Papyri, Part 2. 1907. Edited by Bernard P. Grenfell, Arthur S. Hunt, and Edgar J. Goodspeed. $x \nabla+485$ pages, with 2 collotype plates and a map

vol. 3. The Tebtunis Papyri, Part 3. (In preparation.)

BGYPTIAN ARCHAEOLOGY. (Quarto.)

Vol. 1. The Hearst Medical Papyrus. Edited by G. A. Reisner.

Hieratic text in 17 fac-simile plates in collotype, with introduction and vocabulary, pages 48, 1905. (J. C. Hinrichs, Leipzig, 25 marks.)

Vol. 2. Farly Dynastic Cemeteries of Naga-ed-Der, Part I, by George A. Reisner. zil +160 pages, with 80 plates and 211 text figures. 1908. (J. C. Hinrichs, Leipzig, 75 marks.)

Vol. 3. The Early Dynastic Cemeteries at Naga-ed-Der, Part II, by A. C. Mace. $x i+88$ pages, with 60 plates and 123 text figures. 1909. (J. C. Hinrichs, Leipzig, 50 marks.)

Vol. 4. The Predynastic Cemetery at Nagared-Der. The Anatomical Material, by Flliott Smith. (In preparation.)

Vol. 5. The Cemetery of the Second and Third Dynasties at Naga-ed-Der, by A. C. Mace. (In press.)

Vol. 6. The Cemetery of the Third and Fourth Dynasties at Naga-ed-Der, by C. A. Reisner. (In preparation.)

Vol. 7. The Coptic Cemeteries of Naga-ed-Der, by A. O. Mace. (In preparation.)

\section{SPEOTAL, VOIUMES.}

The Book of the Iffe of the Ancient Mexicans, containing an account of their rites and superstitions; an anonymous Hispano-American manuscript preserved in the Biblioteca Nazionale Centrale, Florence, Italy. Reproduced in fac-simlle, with introduction, translation, and commentary, by Zelia Nuttall.

Part I. Preface, Introduction, and 80 fac-simile plates in colors. 1903.

Part II. Translation and Commentary. (In press.)

Price for the two parts

Fac-simile of a Map of the City and Valley of Mercico, by Alonzo de Santa Cruz, Cosmographer of Philip II of Spain. Explanatory text by Zelia Nuttall. Map in 7 sheets, $17 \times 20$ inches. (In preparation.)

The Department of Anthropology, Its History and Plan, 1905. Sent free on application to the Department, or to the University Press, 


\section{UNIVERSITY OF CALIFORNIA PUBLICATIONS - (CONTINUED)}

Note.-The University of California. Publications are offered in exchange for the publications of learned societies and institutions, universities and libraries. Complete lists of all the publications of the University will be sent upon request. For sample copies, lists of publications or other information, address the Manager of the University Press, Berkeley, California, U. S. A. All matter sent in exchange should be addressed to The Exchange Department, University Iibrary, Berkeley, California, U. S. A.

ASTRONOMY.-W. W. Campbell, Editor. (Lick Observatory, Mt. Hamilton, Cal.)

Publications of the Iick Observatory.-Volumes I-V, VII, and $\mathbf{X}$ completed. Volumes. VII and IX in progress.

BOTANY.-W. A. Setchell, Editor. Price per volume \$3.50. Volumes I (pp. 418), II (pp. 354), and III (pp. 400); completed. Volume IV. (in progress).

CLASSICAI PHILOLOGY._Edward B. Clapp, William A. Merrill, Herbert C. Nutting, Editors. Price per volume \$2.00. Volume I (pp. 270) completed. Volume II (in progress).

ECONOMICS.-A. C. Miller, Editor.

EDUCATION.-Edited by the Department of Education. Price per volume \$2.50.

ENGINEERING.-Fdited under the direction of the Engineering Departments. This series will contain contributions from the Colleges of Mechanics, Mining, and Civil Ingineering. Volume I (in progress).

GEOLOGY.-Bulletin of the Department of Geology. Andrew C. Iawson, Fditor. Frice per volume \$3.50. Volumes I (pp. 428), II (pp. 450), III (475), and IV (462), completed. Volume $\nabla$ (in progress).

MODERN PHILOLOGY.-Volume I in progress.

PATHOLOGY.-Alonzo Finglebert Taylor, Fditor. Price per volume, \$2.50. Volume I (pp. 347) completed.

PHILOSOPHY.-G. H. Howison, Editor. Volume I (pp. 262), completed. Volume II (in progress). Price per volume \$2.00.

PHYSIOLOGY.-Jacques Loeb, Editor. Price per volume \$2.00., Volume I (pp. 217) completed. Volume II (pp. 215) completed. Volume III (in progress).

PSYCHOLOGY.-George M. Stratton, Editor. Vol I (in progress).

ZOOLOGY.-W. E. Ritter and C. A. Kofold, Editors. Price per volume \$3.50. Volumes I (pp. 317), II (pp. 382), III (pp. 383), and IV (pp. 400), completed. Volumes V and VI in progress. Commencing with Volume II, this series contains Contributions from the Laboratory of the Marine Biological Association of San Diego.

MIEMOIRS OF THE UNIVERSITY OF CAIIFORNIA. (Quarto.)

Vol. 1. 1. Triassic Ichthyosauria, with special reference to the American Forms, by John C. Merriam. Pp. 1-196; plates 1-18; 154 text figures. September, 1908 $\$ 3.00$

2. The Silva of Caltfornia, by W. I. Jepson. (In press.)

UNIVERSITY OF CATIFORNIA CHRONICLE.-An official record of University life, issued quarterly, edited by a committee of the Faculty. Price, $\$ 1.00$ per year. Current volume No. XII.

ADMINISTRATIVE BULIETINS OF THE UNIVFRSTTY OF CATIFORNIA,-Edited by the Recorder of the Faculties. Includes the Register, the President's Beport, the Secretary's Report, and other official announcements.

Address all orders or requests for information concerning the above publications to The University Press, Berkeley, California.

European agent for the series in American Archaeology and Ethnology, Classical Philology, Education, Modern Philology, Philosophy, and Semitic Philology, Otto Earrassowitz, Leipzig. For the series in Botany, Geology, Pathology, Physiology, Zoology and also American Archaeology and Fthnology, R. Friedlaender \& Sohn, Berlin 


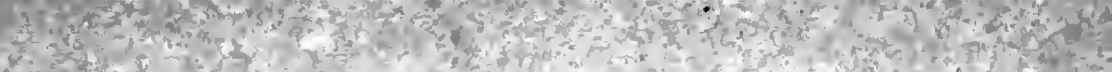

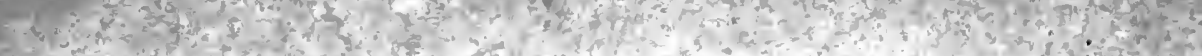
स.

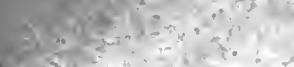

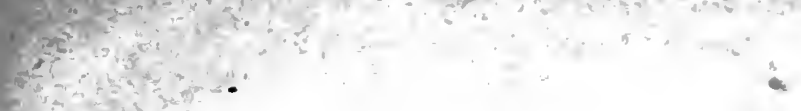

\section{ton}

\section{(3.}

\section{1.}

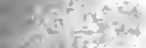

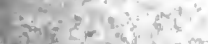

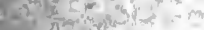

If sto $^{2}$

1. Mrmetive

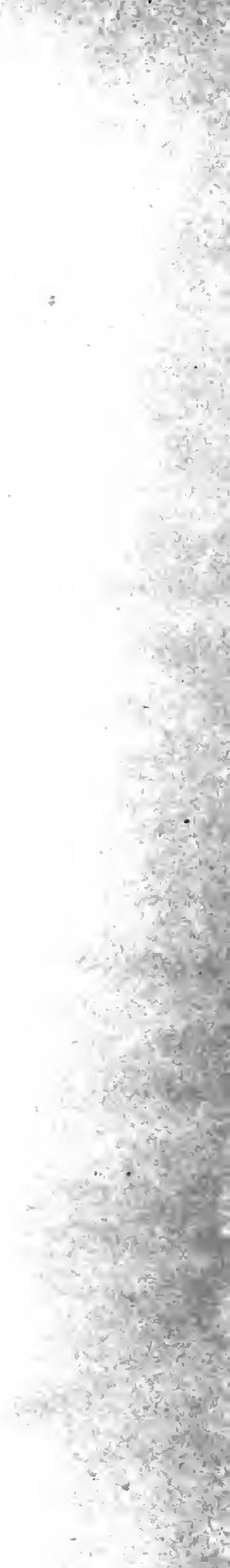




